Florida International University FIU Digital Commons

7-19-2001

\title{
Melt inclusions from volcan de Colima, Mexico: complex examples of magmatic differentiation
}

Zachary D. Atlas

Florida International University

DOI: $10.25148 /$ etd.FI14032368

Follow this and additional works at: https://digitalcommons.fiu.edu/etd

Part of the Geology Commons

\section{Recommended Citation}

Atlas, Zachary D., "Melt inclusions from volcan de Colima, Mexico: complex examples of magmatic differentiation" (2001). FIU Electronic Theses and Dissertations. 1334.

https://digitalcommons.fiu.edu/etd/1334 
FLORIDA INTERNATIONAL UNIVERSITY

Miami, Florida

MELT INCLUSIONS FROM VOLCÁN DE COLIMA, MEXICO: COMPLEX EXAMPLES OF MAGMATIC DIFFERENTIATION

A thesis submitted in partial fulfilment of the requirements for the degree of MASTER OF SCIENCE in GEOLOGY by

Zachary D. Atlas 
To: Dean Arthur W. Herriott

College of Arts and Sciences

This thesis, written by Zachary D. Atlas, and entitled Melt Inclusions From Volcán de Colima, Mexico: Complex Examples of Magmatic Differentiation, having been approved in respect to style and intellectual content, is referred to you for judgment.

We have read this thesis and recommend that it be approved.

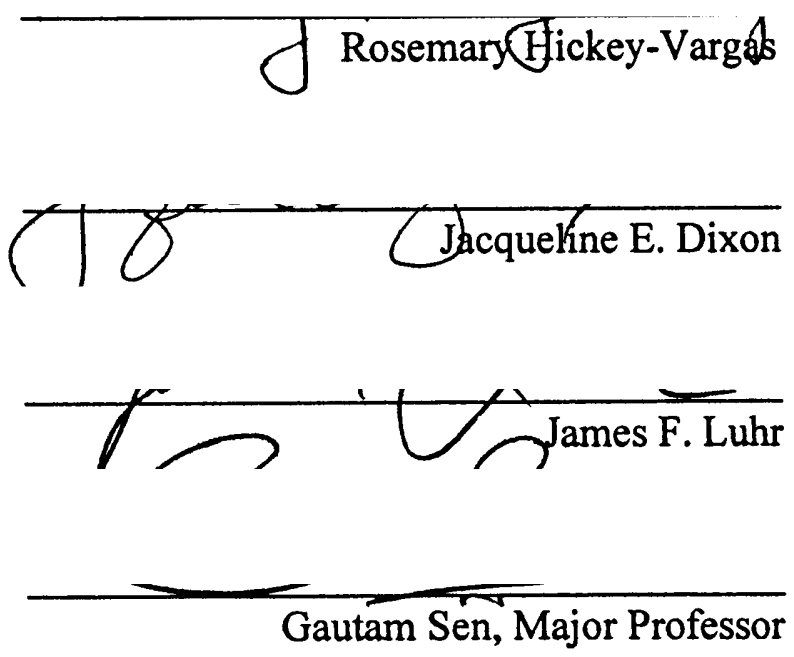

Date of Defense: July 19, 2001

The thesis of Zachary D. Atlas is approved.

Dean Arthur W. Herriott

College of Arts and Sciences

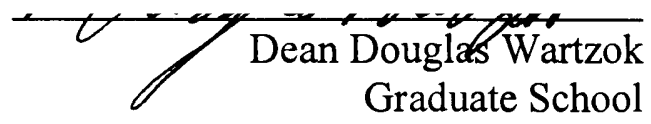

Florida International University 


\section{DEDICATION}

This thesis is dedicated to my loving wife Silvia. Her patience, support and steadfast realism have allowed me to keep my goals in sight and to strive for the highest possible achievement. 


\section{ACKNOWLEDGMENTS}

This project was completed with the assistance of numerous people. First and foremost I would like to extend my deepest gratitude towards my major professor Gautam Sen for his many enlightening discussions and guidance. I would also like to extend many thanks to my committee members, Drs. Rosemary Hickey-Vargas and Jacqueline Dixon, without whom the numerous aspects of this work would not have come together. Particularly, I would like to express my gratitude to Dr. James F. Luhr for the donation of samples from the Smithsonian Institutions Museum of Natural History.

I would also like to thank various people whom contributed to the completion of this project. First, many, many thanks to Tom Beasley for his many hours spent with me on the Microprobe, SEM, and 1 Atmosphere furnace. And to Dr. Richard Hervig, for graciously allowing me to use ASU's Ion Probe and for his insight into this project. Many thanks as well to Amitava Gangophadyay for his help in sample preparation and experimentation. Of course I must acknowledge Rosa Nicolardes and Carolin Medina for going well beyond the call of duty to assist me in the thousands of administrative tasks encountered during my graduate study at FIU. Thanks also to Diane Perrie for her photographic expertise and help with laboratory work. A heartfelt thank you must go out to Sandeep Rehki for many helpful discussions and fine food for thought. I also would like to express my profound gratitude to my colleagues Shantanu Keshav \& Sedelia Durand for their many discussions on this project. Finally, I wish to thank all my family for their love and support. 


\title{
MELT INCLUSIONS FROM VOLCÁN DE COLIMA, MEXICO: COMPLEX EXAMPLES OF MAGMATIC DIFFERENTIATION
}

by

\author{
Zachary D. Atlas \\ Florida International University, 2001 \\ Miami, Florida \\ Professor Gautam Sen, Major Professor
}

Melt inclusions are minute magma bodies trapped within growing crystals. Their chemical compositions are useful in deciphering pre-eruptive conditions and magma evolution. The present study examined melt inclusions trapped in phenocrysts from the $3^{\text {rd }}$ and $4^{\text {th }}$ magmatic cycles $(1869-1988)$ at Volcán de Colima, Mexico. Melt inclusions have highly evolved chemical compositions: $65-77 \% \mathrm{SiO}_{2},>12 \% \mathrm{Al}_{2} \mathrm{O}_{3}, 3-6 \% \mathrm{Na}_{2} \mathrm{O}$ and $\mathrm{K}_{2} \mathrm{O}$ and less than $5.5 \% \mathrm{Fe}$ and $\mathrm{Mg}$. Major element compositions suggest that they are strongly differentiated magmas controlled by fractionation of plagioclase, opx, cpx and hornblende. Water concentrations were measured to be $2.7-3.5 \mathrm{wt} \% \%$ in cpx hosted inclusions and 0.3-0.7 wt \% in opx and plagioclase. Trace element compositions are anomalously low and inversely correlate with water. From this we deduce that Colima lavas and scorias simultaneously differentiate and degas. Moreover, hornblende rim growth rates constrain the ascent of the Colima magmas to $\sim 100$ days for passive eruptions and $>4$ days for plinian eruptions. 
2: GEOLOGY AND HISTORY OF THE COLIMA VOLCANIC COMPLEX _...... 3

2.1 Tectonic setting and development of the Colima Volcanic Complex..... 3

2.2 Magmatic products and their interpretation 7

3: MELT INCLUSION STUDIES

3.1 The significance of melt inclusions

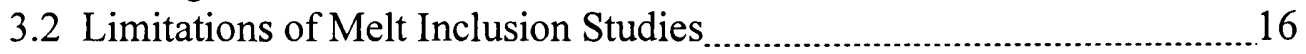

4: METHODS

4.1 Sample Preparation

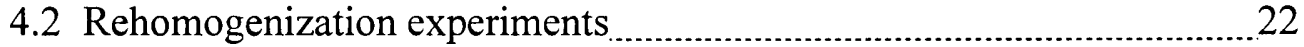

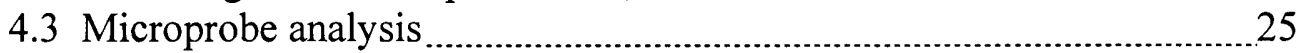

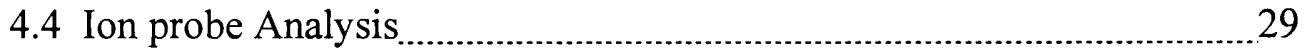

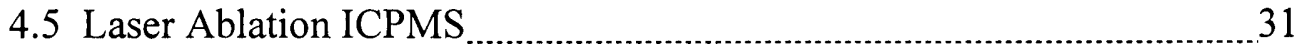

5: PETROGRAPHY

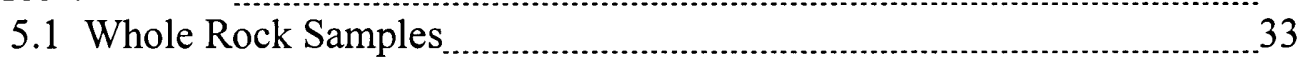

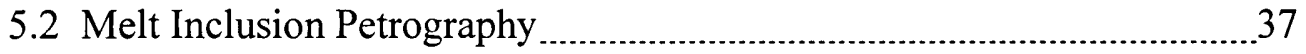

6: RESULTS

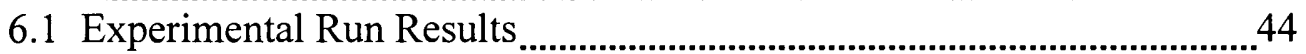

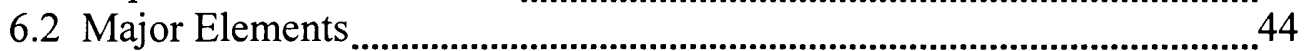

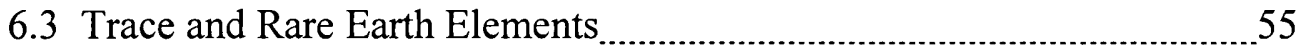

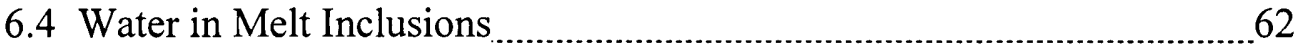

CHAPTER 7: DISCUSSION

CHAPTER 8: CONCLUSIONS

REFERENCES

APPENDICES 


\section{LIST OF TABLES}

TABLE

PAGE

Table 4-1: Temperature, $f_{0} 2$ and run duration for all controlled fugacity, 23 $1 \mathrm{~atm}$. experiments.

Table 6-1: Run results for DI-194 samples (1869 lava flow). 45

Table 6-2: Run results for controlled fugacity experiments. 45

Table 6-3: EPMA analysis of secondary crystals in plagioclase MI's. 46

Table 6-4: EPMA Analysis of melt inclusions in natural samples from 48 Fuego de Colima (1869-1913)

Table 6-5: EPMA analysis of melt inclusions from controlled fugacity 49 rehomogenization experiments on sample DI-194 (1869).

Table 6-6: EPMA analysis of 1 atmosphere re-homogenization experiments. 50

Table 6-7: Major and trace element analyses of melt inclusions. 56 


\section{LIST OF FIGURES}

FIGURE

PAGE

Figure 2-1: Placement of Colima complex within the triple rift system and 4 southern Colima graben.

Figure 2-2: Map view of the Colima rift valley. 5

Figure 2-3: Eruptive cycles of Fuego de Colima for the past 500 years 9

Figure 2-4: $\mathrm{SiO}_{2}$ vs. $\mathrm{K}_{2} \mathrm{O}$ diagram for Nevado de Colima and Fuego de Colima.....10

Figure 2-5: Plots of major element variation for the last two major 11 magmatic cycles of Volcán de Colima.

Figure 3-1: Rhyolitic pumice, ignimbrite $\&$ tephra from the western 14 United States and their respective melt inclusions

Figure 3-2: Andesite and Rhyolite Melt Inclusions. 15

Figure 3-3: Comparison of transmitted light image and back-scatter image. 18

Figure 4-1: Sample DI-194 showing plagioclase with clear core, 20 zoned rim and ring of melt inclusions

Figure 4-2 Design of a platinum-wound one-atmosphere gas-mixing furnace. 21

Figure 4-3: Plot of $\log f_{\mathrm{O}_{2}}$ versus temperature. 23

Figure 4-4: Probe diameter measurements. 27

Figure 4-5: Sodium loss calibration curves 28

Figure 4-6: $\mathrm{H}_{2} \mathrm{O}$ calibration graph for NIST 610, M3N and M6N standards. 30

Figure 5-1: Photomicrograph of samples DI-194, 1004-407 \& 1004-414. 34

Figure 5-2: Photomicrograph of sample M82-11 and JT 91-68. 35

Figure 5-3: Photomicrograph of sample 1004-421. 36

Figure 5-4: Photomicrograph of plagioclase with a high concentration 39 of melt inclusions in its core from sample Col-9D. 
Figure 5-5: Photomicrographs of plagioclase melt inclusions. 39

Figure 5-6: Photomicrograph of brown de-vitrified inclusions in 40 plagioclase from sample 1004-421.

Figure 5-7: Melt inclusions after re-homogenization at $1150^{\circ} \mathrm{C}$. 41

Figure 5-8: Melt inclusion after re-homogenization experiment showing 41 multiple vapor bubbles.

Figure 5-9: Melt inclusions after re-homogenization at $1090^{\circ} \mathrm{C}$ showing 42 secondary crystals.

Figure 5-10: Plagioclase crystal after re-homogenization showing both 42 vitreous and de-vitrified melt inclusions.

Figure 5-11: Melt inclusions in hornblende and pyroxene from sample 1004-421...43

Figure 6-1: Harker diagrams showing the variation of the major elements 51 for nonhomogenized melt inclusions

Figure 6-2: Harker diagrams showing the variation of the major elements 53 for atmospheric runs

Figure 6-3: Harker diagrams showing the variation of the major elements 54 for controlled fugacity runs

Figure 6-4: Spider diagram of trace elements for Colima melt inclusions. 57

Figure 6-5: Spider diagram of trace element models for Colima melt 60 inclusions.

Figure 6-6: Stability fields for plagioclase, orthopyroxene, clinopyroxene, 63 hornblende and magnetite as a function of pressure and temperature for Volcán de Colima.

Figure 7-1: Plots of $\mathrm{Al}_{2} \mathrm{O}_{3}$ and $\mathrm{FeO}$ versus $\mathrm{CaO}$. 65

Figure 7-2: Plot of $\mathrm{Na}_{2} \mathrm{O}$ vs. $\mathrm{SiO}_{2}$. 66

Figure 7-3: Spider diagram of REE's in Colima melt inclusions. 69

Figure 7-4: Plot of major element compositions versus $\mathrm{H}_{2} \mathrm{O}$. 70 
Figure 7-5: Plot of selected trace elements from Colima melt inclusions versus $\mathrm{H}_{2} \mathrm{O}$.

Figure 7-6: Plot of $\mathrm{H}_{2} \mathrm{O}$ versus $\mathrm{K}_{2} \mathrm{O}$ for Colima and Popocatépetl. 72 melt inclusions

Figure 7-7: Water saturation curves. 74

Figure 7-8: Plot of phase stability for Colima, Mt. St. Helens (MSH) 78 and for basaltic andesite.

Figure 7-9: Ascent rate curves derived from hornblende rim growth. 79 


\section{CHAPTER 1: INTRODUCTION}

Volcán de Colima (Mexico) is situated within a triple rift system adjacent to a subduction zone. This unusual tectonic setting coupled with a history of regularly occurring eruptions has made it an intriguing target of study for volcanologists. The Colima-Cantaro Complex consists of three volcanoes that have evolved southward along the rift valley through time. Historically, each of these volcanoes shows evidence for periods of effusive (strombolian type) activity punctuated by major eruptions (Luhr and Carmichael, 1990). Large dome collapse events have also destroyed each cone at least once during their development (Luhr, 1993). This pattern of activity makes Colima an important natural laboratory in need of further study. Furthermore, the proximity of these volcanoes to major population centers makes their study important for hazard mitigation.

Colima lavas form a tight group of medium K andesite (Luhr \& Carmichael 1990, Luhr and Kyser 1989, Verma \& Luhr 1992, Robin et al. 1993, Robin et al. 1990). Numerous chemical analyses on lavas and tephra have shown distinctive temporal trends for the past 200 years (Luhr \& Carmichael 1990). To date, no study has fully addressed the melt inclusions found in the phenocrysts of Colima lavas. Melt inclusions have been used by a number of workers in other parts of the world to infer chemical conditions occurring in the magma chamber prior to eruption (Nielsen et al, 1985, Roedder, 1984 Sours-Page et al, 1998). Therefore, a study of Colima's melt inclusions was deemed important for deciphering the subsurface magmatic processes that cause its recurring major eruptions. 
The present work focuses on melt inclusions entrapped in phenocrysts from block lavas erupted in 1869, 1880 and from one scoria sample erupted in 1913. This study presents the major element compositions of Colima melt inclusions. It also includes the first report of ion probe analysis of concentrations of water and trace elements in Colima melt inclusions. These data, in conjunction with analytical petrography of the hornblendes found in these lavas, are used to decipher crystallization versus degassing history of Colima lavas. 


\section{CHAPTER 2: THE COLIMA VOLCANIC COMPLEX}

\subsection{Tectonic setting and development of the Colima Volcanic Complex}

Fuego de Colima is part of a system of volcanoes collectively known as the Colima volcanic complex. The complex includes Volcán Cantaro, Nevado de Colima and the presently active Fuego de Colima and is located within the southern arm of a triple rift system in west central Mexico (Fig 2-1). The triple rift includes the Colima graben, the Tepic-Zacoalco rift (including Volcán Ceborucco) and the Chapala Rift (including Lake Chapala and associated geyser fields). The Colima rift is approximately $50 \mathrm{~km}$ wide. It is bounded by a series of N-S trending normal faults in the north and NESW trending faults in the southern portion of the rift valley (Bandy et al., 1995). Fuego de Colima lies central in the rift valley located at $19^{\circ} 30^{\prime} 44^{\prime \prime} \mathrm{N}, 103^{\circ} 37^{\prime} 02^{\prime \prime} \mathrm{W}$. The complex is approximately $150 \mathrm{~km}$ northeast of the Middle America Trench and is closer to the trench than any other volcanic center in the Trans-Mexican Volcanic Belt. Fuego and Nevado de Colima stand approximately $4000 \mathrm{~m}$ high making them the main topographic features in the surrounding valley. The remainder of the rift valley is spotted with small cinder cones typically less than $500 \mathrm{~m}$ high. Cinder cones have been intensely studied (Luhr \& Kyser, 1989; Luhr \& Carmichael, 1981, 1982) and many of these products are chemically unlike the magmatic products erupted from the main vents.

Volcanic activity in this area has shifted southward through time (Fig 2-2) from Cantaro in the north to Nevado (central) to Fuego de Colima at the southern end of the complex (Luhr \& Carmichael, 1980 \& 1990; Robin et al., 1982; Calanchi et al., 1995). 


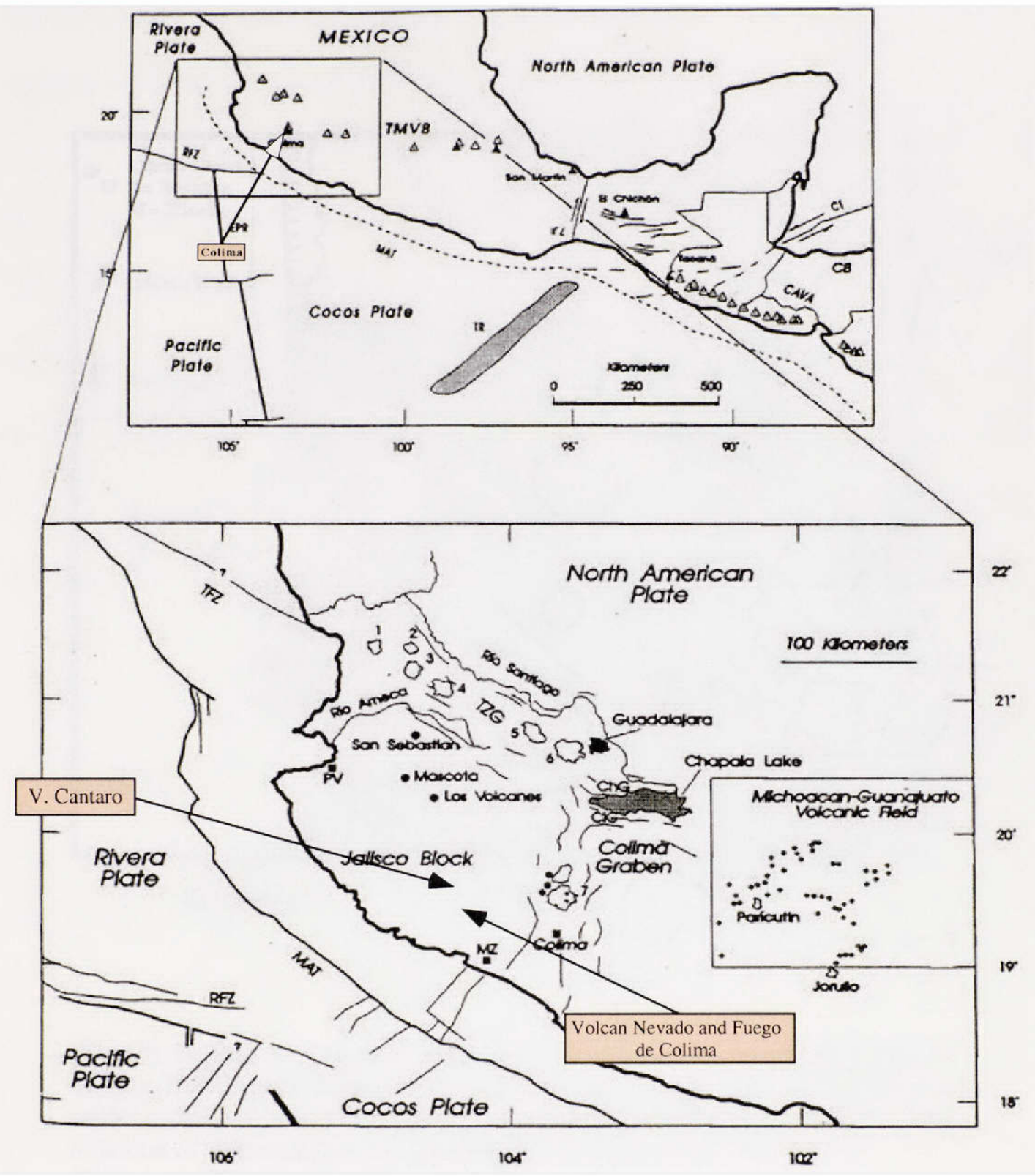

Figure 2-1. Placement of Colima complex within the triplerift system and southern Colima graben. Figure modified from Macias et al., 1993. The top part shows the location of Colima complex relative to the TMVB. 


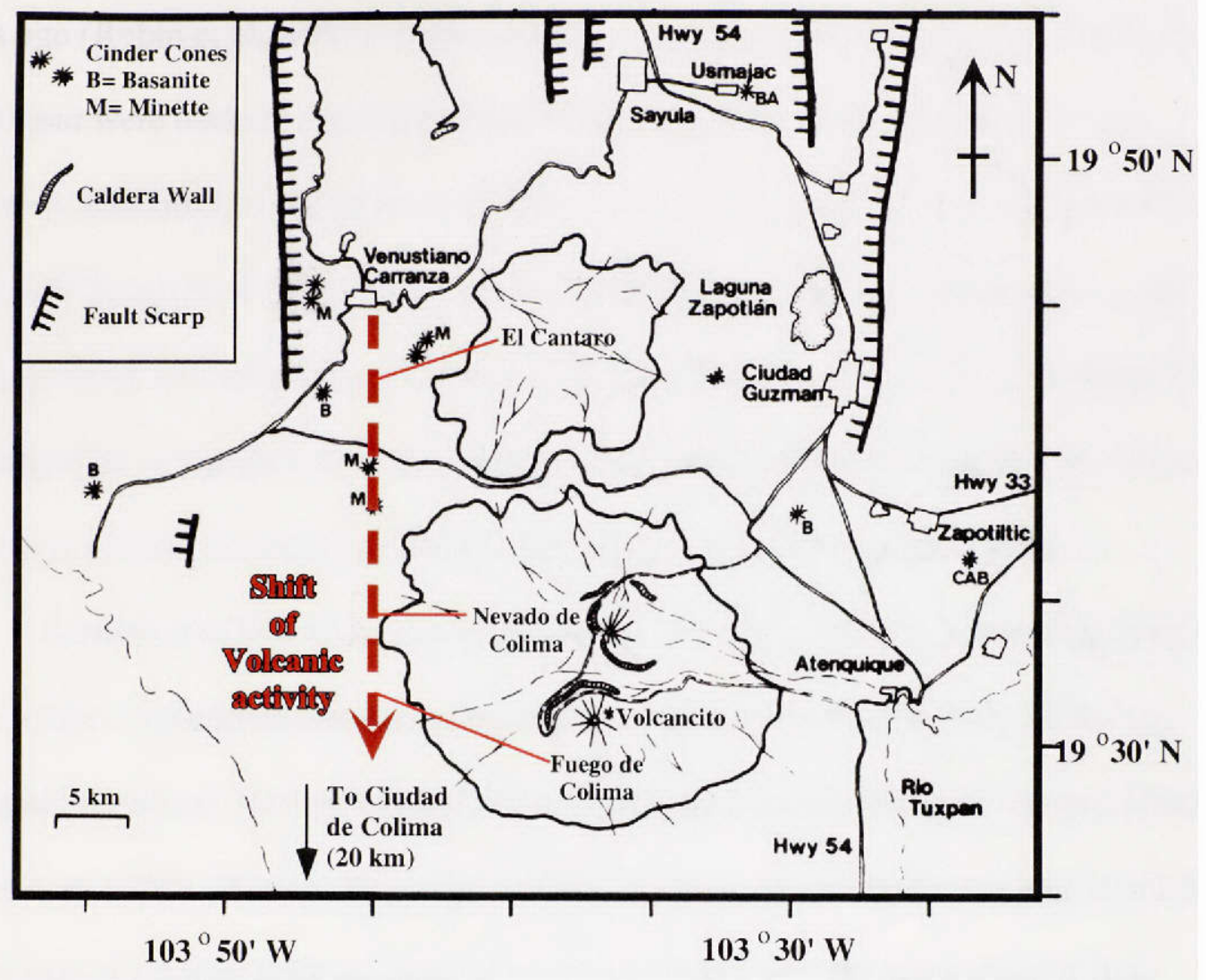

Figure 2-2: Map view of the Colima rift valley showing the location of Fuego de Colima, Nevado de Colima and V. Cantaro relative to the graben walls (fault scarps), cinder cones and nearby population centers. Red Dashed arrow show the relative direction of shift in the focus of activity for Colima over the past 1.7 Ma.

(Figure modified fom Luhr \& Carmichael, 1980) 
All volcanic activity in the area is of Quaternary age, with activity at Volcán Cantaro beginning approximately 1.7 Ma b.p. (Calanchi et al., 1995). Fuego de Colima began erupting contemporaneously with the most recent Nevado cone less than 80 thousand years ago (Robin et al., 1987). Unfortunately, all of the initial traces of activity at Fuego de Colima were buried or erased by the avalanche collapse of the prehistoric cone between $\sim 9300$ and $\sim 4300$ years ago (Robin et al., 1987; Luhr, 1993), and therefore, this age is still in question. Subsequent to the collapse, minor activity commenced on the southern flank of Fuego de Colima (Los Hijos de Colima), additionally illustrating the southern shift of volcanic activity (Luhr \& Carmichael, 1990). During the last 100 years activity at Colima has been confined to the central vent of Fuego de Colima.

A number of hypotheses have been proposed to explain this interesting tectonic environment. One hypothesis proposes that part of the East Pacific Rise (EPR) has "jumped" eastward over the subduction zone and has induced rifting in western Mexico (Luhr et al, 1985). Further, this ridge shifting has been occurring for the past 10-12 Ma and is part of a major plate reorganization that initialed with the separation of Baja California in the Miocene. A recent paleomagnetic investigation offers evidence of continental rifting occurring in this area as far back as the Upper Cretaceous (Housen \& Beck, 1999). The possibility exists that this area has long been a location for major continental plate reorganization. Other hypotheses suggest that tensional forces associated with subduction of the Rivera-Cocos plate boundary created the triple rift (Bandy et al., 1995). It has also been proposed that oblique subduction of the Cocos plate is causing shear forces that created and perpetuates the rift (DeMets \& Stein, 1990). These issues have yet to be resolved. 


\subsection{Magmatic products and their interpretations}

A considerable amount of work on lavas from the Colima complex has been performed (Luhr \& Carmichael, 1980; Luhr \& Carmichael, 1981; Luhr \& Carmichael, 1982; Luhr \& Carmichael, 1990; Luhr and Kyser, 1989; Verma \& Luhr, 1992; Robin et al., 1990; Robin et al., 1992). A brief description of prehistoric and modern lava from the complex is given to provide a context in which we may interpret melt inclusion data. Lava from Nevado de Colima has varied from basic andesites $\left(57.5 \mathrm{wt}\right.$ \% $\mathrm{SiO}_{2}$, Robin et al., 1987) containing abundant phenocrysts of plagioclase, orthopyroxene and clinopyroxene to more silicic andesites and dacites (61-64.3 wt. \% SiO2) containing abundant amphibole (Robin et al., 1987; Calanchi et al., 1995). Like Nevado, Fuego's phenocrysts also vary over time. Some lava flows contain little or no amphibole, while others contain abundant amphibole (up to $\sim 10 \%$ hornblende, Luhr \& Carmichael, 1990). Still other flows contain only amphibole relics (Luhr and Carmichael, 1990). Colima andesites also contain varying amounts of orthopyroxene, clinopyroxene, plagioclase and titanomagnetite.

Since 1818 Fuego de Colima's eruptions have been well documented (e.g., Luhr \& Carmichael, 1980 \& 1990, Robin et al., 1982, Calanchi et al., 1995). Based on such documentation, Luhr and Carmichael (1990) state that major eruptions (VEI >3) occur every $\sim 100$ years with dome building events thereafter for $40-50$ years. They define this as the eruptive cycle of Fuego de Colima. During the cycle the volcano is never dormant. Active degassing of the volcano occurs almost constantly. Measurements of $\mathrm{SO}_{2}$ flux have been regularly monitored at Colima for the past few decades. Taran et al. (2000) 
reports $\mathrm{SO}_{2}$ flux to be approximately 100 tons/day during the period 1991-1994. In periods of activity $\mathrm{SO}_{2}$ flux can be much higher and have been measured at $>10,000$ tons/day (Smithsonian GVP, volcanic activity report). For 40-50 years prior to a major eruption, lava flows and minor phreato-magmatic eruptions $(\mathrm{VEI}<2)$ occur $(\mathrm{Luhr}$ and Carmichael, 1990, Robin et al., 1987). Large eruptions (VEI = 4) close out the eruptive cycles and have occurred at Fuego in 1585, 1606, 1622, 1818, 1890 and 1913 (De la Cruz-Reyna, 1993). Figure 2-3 shows the eruptive cycle of Fuego de Colima.

Chemically Fuego de Colima lavas are mainly medium-K andesites (Fig. 2-4). As with eruptive style, major element composition can also be seen to cycle over the period of the last 200 years (Fig. 2-5) (Luhr \& Carmichael, 1990; Robin et al., 1987). Each chemical cycle begins with the eruption of basaltic andesite magmas [these scorias have $\mathrm{SiO} 2 \leq 59 \%, \mathrm{MgO} \approx 4.0 \%, \mathrm{FeO} \approx 6.5 \%$ (Luhr \& Carmichael, 1990)]. Succeeding eruptions become more evolved throughout this magmatic cycle $\left(\mathrm{SiO}_{2}\right.$ increases to 60 $62 \%, \mathrm{MgO}$ decreases to $2.5-3.5 \%$ and $\mathrm{FeO}$ decreases to $4.5-5.5 \%)$. We hereafter use the term "magmatic cycle" to refer to the chemical cycle. We also prefer magmatic cycle starting eruptions to refer to the violent eruptions of $1818 \& 1913$ eruptions because it is believed that these primitive magmas represent new magma batches fed into the chamber (Robin et al., 1991; Robin \& Potrel, 1993). Hypotheses concerning the origin and evolution of these lavas include (1) fractional crystallization of plagioclase + hornblende + clinopyroxene + titanomagnetite (Luhr, 1992; Calanchi et al., 1995; and Macías et al., 1993); and (2) magma mixing coupled with fractional crystallization (Luhr \& Carmichael, 1990; Verma \& Luhr, 1993; Robin \& Potrel, 1993; Robin et al., 1991) 


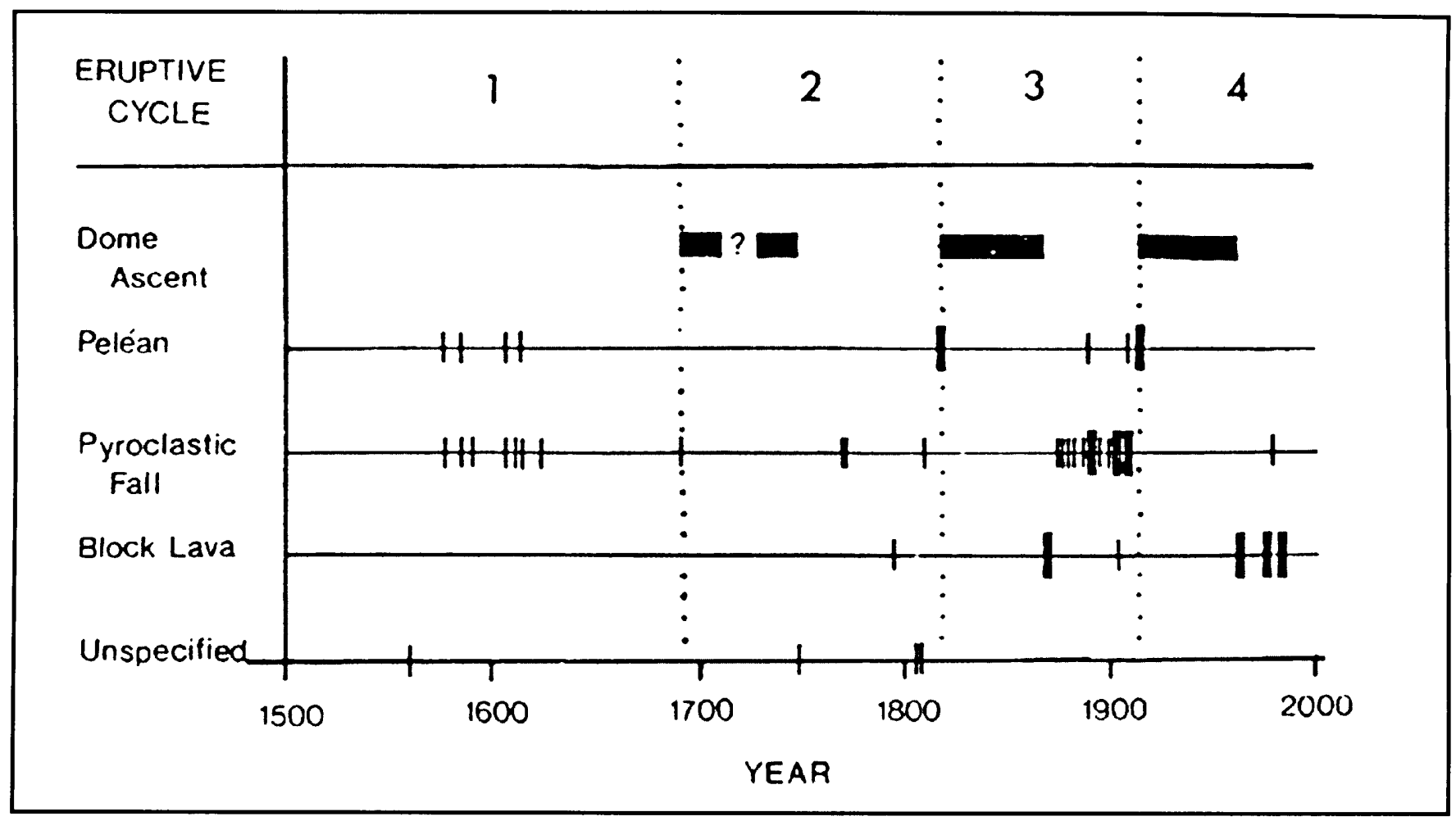

Figure 2-3. Event cyclicty of Fuego de Colima for the past 500 years. Figure from Luhr and Carmichael 1990 


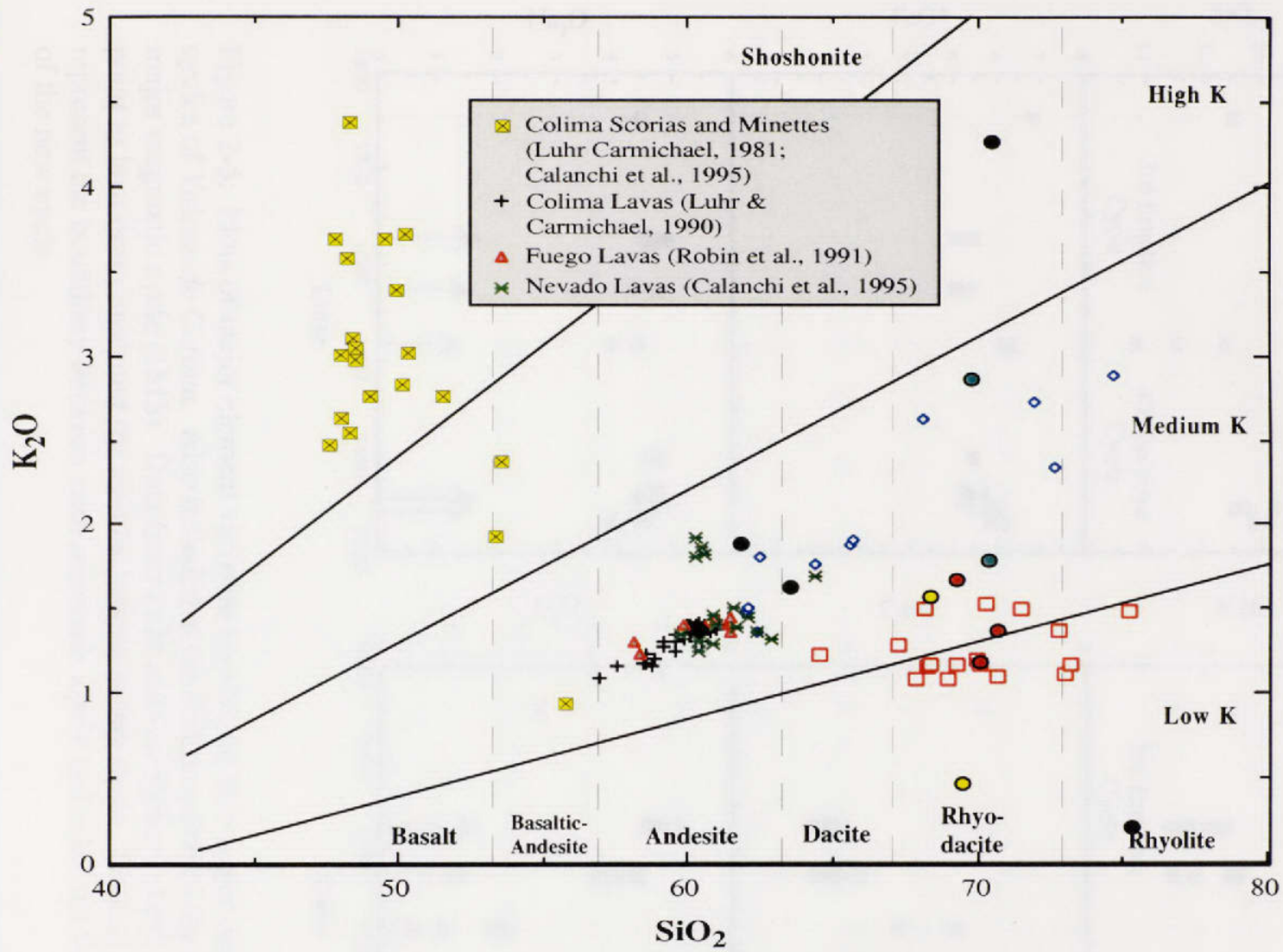

Figure 2-4: $\mathrm{SiO} 2$ vs K2O diagram (After Gill 1981) showing lavas from Nevado de Colima and Fuego de Colima. Scorias and minettes from the Colima Cinder Cones. Colima MI's (this study) are also plotted for comparison ( $\square$ $=1 \mathrm{~atm}$. runs, ${ }^{\circ}=\mathrm{CF}$ runs, $\boldsymbol{0}=$ inclusions in $\operatorname{cpx}, \boldsymbol{\bullet}=$ in opx, $\mathrm{O}=$ in hornblende $\& \bullet=$ in plagioclase inclusions). 

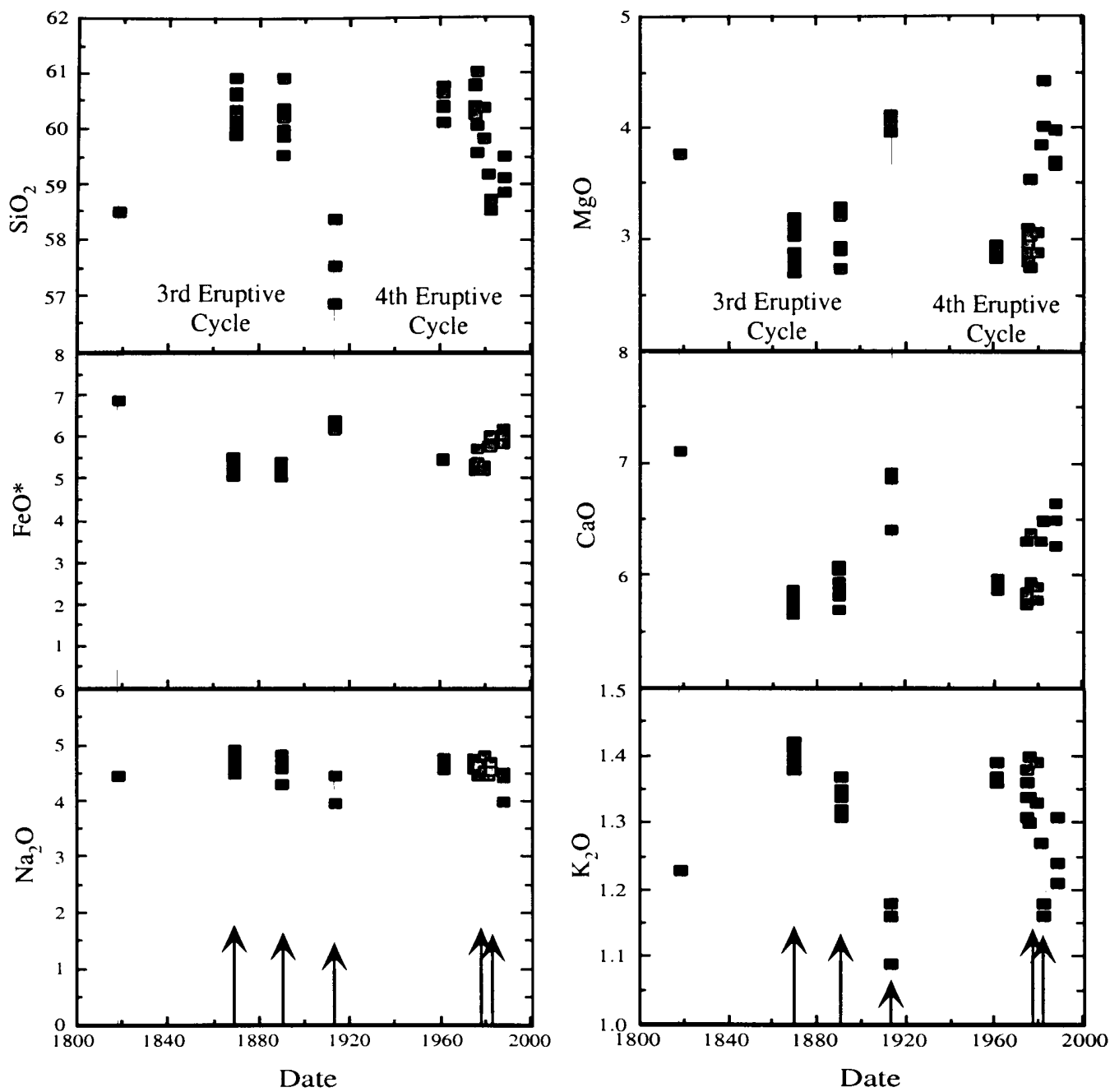

Figure 2-5: Plots of major element variation for the last two major magmatic cycles of Volcan de Colima. Also included is the first eruption of the second major magmatic cycle (1818). Data from Luhr and Carmichael (1990). Arrows point to lava flows analyzed for melt inclusions in this study. Dashed lined represent the boundrary between each magmatic cycle and mark the first eruption of the new cycle. 


\section{CHAPTER 3: Melt Inclusion Studies}

\subsection{The significance of melt inclusions}

Geochemical studies of igneous rocks provide us with an insight into the nature of volcanic processes. Although lavas record source characteristics, differentiation and contamination processes, important information about the magmatic history may be lost or overprinted by irreversible near surface processes, such as magma degassing. In some cases significant inferences about the pre-eruptive magmas may be obtained through the study of melt inclusions (MI's) (Nielsen et al, 1995; Lee \& Stern, 1998; Gioncada et al., 1998). MI's are small pockets of silicate glass that are entrapped by rapidly growing crystals (Roedder, 1984). They are commonly found in olivine, plagioclase, quartz and diamond but can occur in almost any other crystal under the right conditions of formation (USGS melt inclusion page, from internet). Early studies reported MI's to be a sample of the initial melt from which the phenocryst grew (Sommer, 1977). More recent studies demonstrate that MI's are representative of the magma coexisting in equilibrium with the growing crystal at any given point in time (Kamenetsky et al., 1997; Vaggelli et al. 1993; Roedder, 1984, 1991; Vogel \& Aines, 1996; Dunbar \& Hervig, 1992).

Melt inclusions have been extensively studied in phenocrysts of mid ocean ridge basalts (MORB) (e.g., Sours-Page et al., 1999; Kamenetsky et al., 1997; Nielsen et al., 1995; Sinton et al., 1993), rhyolite (e.g., Vogel \& Aines, 1996; Dunbar \& Hervig, 1992), and mantle xenoliths (e.g., Schiano et al., 2000; Schiano \& Bourdon, 1999; Varela et al., 1999). In these settings MI's are chemically similar to or more primitive than bulk magmas. They have been interpreted as being either primary melts (Nielsen et al., 1995; 
Sinton et al., 1993) or residual melts who's composition has been controlled by crystal fractionation and magma mixing (Sours-Page et al., 1999; Vogel \& Aines, 1996; Dunbar \& Hervig, 1992; Webster \& Duffield, 1991) (Figs. 3-1).

In contrast to the above, the present study is concerned with MI's found in phenocrysts of andesitic rocks. Unfortunately, only a few studies have been performed on andesite hosted MI's (Sisson \& Layne, 1993; Finny, 2000; Wardell et al., 2001). These prior studies have shown that MI's in andesites are very different than MI's found in MORB, rhyolite and mantle xenoliths. The former have wide ranges of chemical composition and in many cases contain more than $75 \% \mathrm{SiO}_{2}$ even though their host magmas show no signs of this extreme composition (Figure 3-2). In general, andesitic MI's are highly evolved and seem to represent products of extreme magmatic differentiation.

Of particular importance to MI studies is their volatile content. If melt inclusions are representative of the melt from which the phenocryst grew (or representative of the evolving magma), then the volitile components contained in melt inclusions must represent magmatic volatile contents (Webster \& Duffield, 1991). Because volatiles have drastic effects on silicate melts, knowledge of their pre-eruptive concentrations is crucial to our understanding of magmatic phase equilibria (Holloway \& Blank, 1994). An important application of dissolved water content of melts is that the depth at which a MI is trapped may be deciphered from such data (Roedder 1984; Sommer, 1979, Dunbar \& Hervig, 1992; Roggensack, 2001; Wardell et al., 2001). In this way, volatile contents may be helpful for determining the pressures at which differentiation processes occur. 


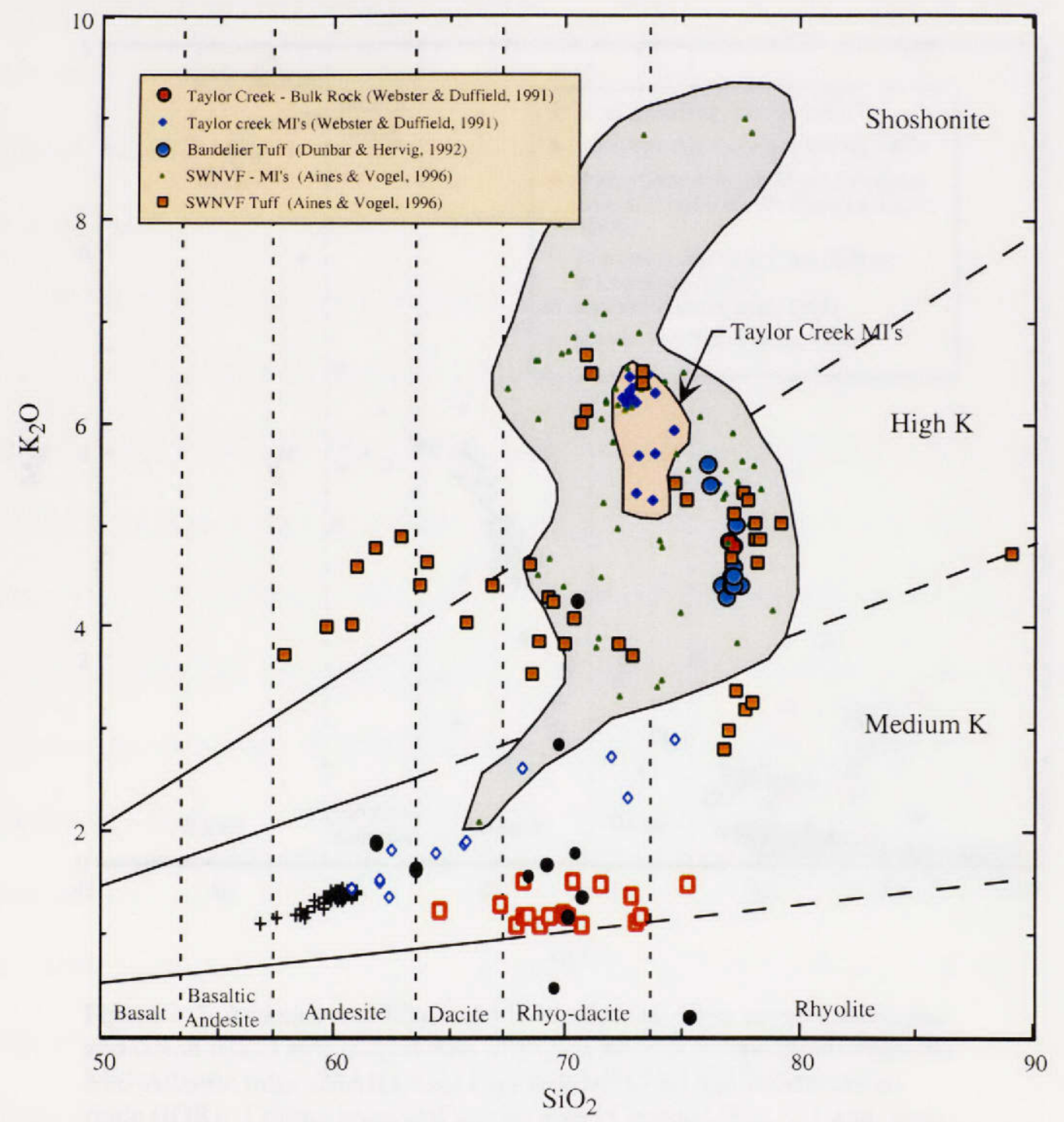

Figure 3-1: Rhyolitic pumice, ignimbrite \& tephra from the western United States and their respective melt inclusions plotted on a $\mathrm{K}_{2} \mathrm{O}-\mathrm{SiO}_{2}$ variation diagram (Gill, 1981). Data represents samples from the Bandelier tuff. Taylor Creek and Southwest Nevada Volcanic Field (SWNVF). Colima lava $\left(^{+}\right.$) and MI's ( ${ }^{1}$ atm. runs, ${ }^{\circ}$ CF runs, ${ }^{\bullet}$ non-homogenized samples are plotted for reference (see Fig. 2-3 to distinguish between cpx,opx, hbl., and plag. hosted inclusions in non-homogenized analyses) 


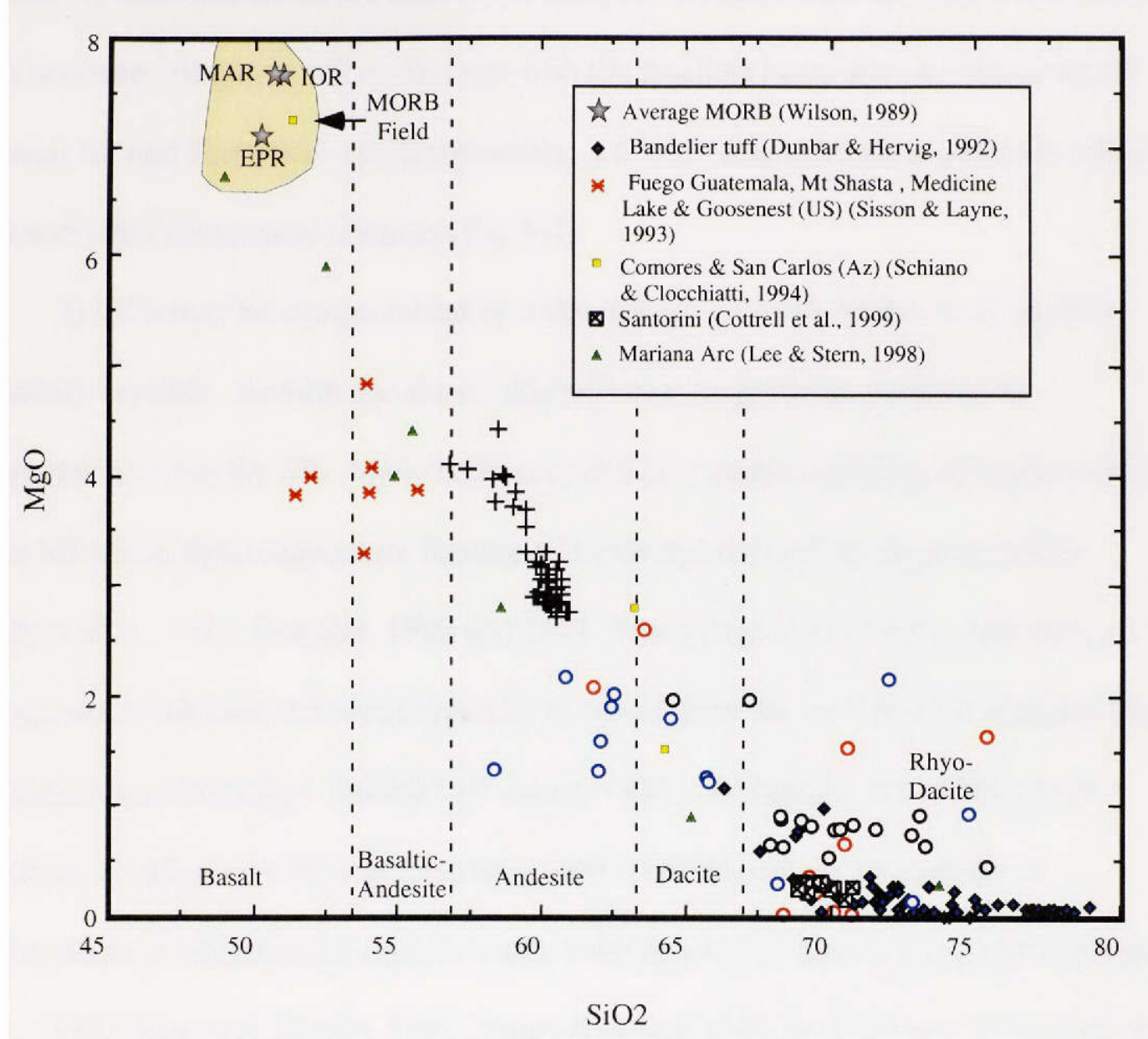

Figure 3-2: Andesite and Rhyolite Melt Inclusions form sevral continental and ocean island arcs plotted with averaged MORB compositions from the Mid-Atlantic ridge (MAR), East Pacific Rise (EPR) and Indian Ocean rigde (IOR). Colima lavas and scorias + and Colima MI's [ $\circ 1$ atm. runs, - CF runs \& o non-homogenized samples are shown for reference (see Fig. 2-3 to distinguish between cpx, opx, hbl. \& plag. hosted inclusions)]. (Colima data from Luhr \& Carmichael, 1990 and this study) 


\subsection{Limitations of Melt Inclusion Studies}

Although it is apparent that the study of MI's is highly desirable, certain obstacles remain. 1) Melt inclusions are difficult to analyze. Because MI's are very small (most MI's measure $100 \mu \mathrm{m}$ to $<25 \mu \mathrm{m}$ ), even with the smallest beam size, a "mixed signal" between MI and host phase is often possible. MI's are also difficult to detect in reflected light and often backscatter imaging (Fig 3-4).

2) MI's may be compromised by a through-going crack or they may contain secondary crystals. As with the above, this will cause significant variation in composition across the MI. Many authors re-dissolve (rehomogenize) secondary crystals in the MI's in a high temperature furnace or 1 atmosphere heating stage assembly (Nielsen et al., 1995, Roedder, 1990 and 1984, Sours-Page et al., 1999). However, at atmospheric pressures, the vapor typically exsolves from the melt in a MI creating a postentrapment (or shrinkage) "bubble" (Roedder, 1984). Although vapor bubbles are indicative of rehomogenization (Roedder, 1984), this should not be considered confirmation of rehomogenization as vapor bubbles are common in many MI's (Nielsen et al., 1998; Dunbar \& Hervig, 1992; Vogel \& Aines, 1996; and others). Therefore, these "bubbles" also must be avoided during analysis for the same reasons stated for secondary crystals.

3) Re-heating is generally performed on mineral separates. During mineral separation fractures can develop. Upon re-heating melting can preferentially occur along these fractures, significantly altering their composition. Highly incompatible elements, volatile elements and vapor can leak out through these cracks (Nakamura \& Shimakita, 1998). Furthermore, the furnace atmosphere (which is easily exchanged through the 
fractures) can also significantly change iron content of the MI and host effecting equilibrium (Nielsen et al., 1998). This can lead to an inaccurate interpretation of MI's chemistry. 

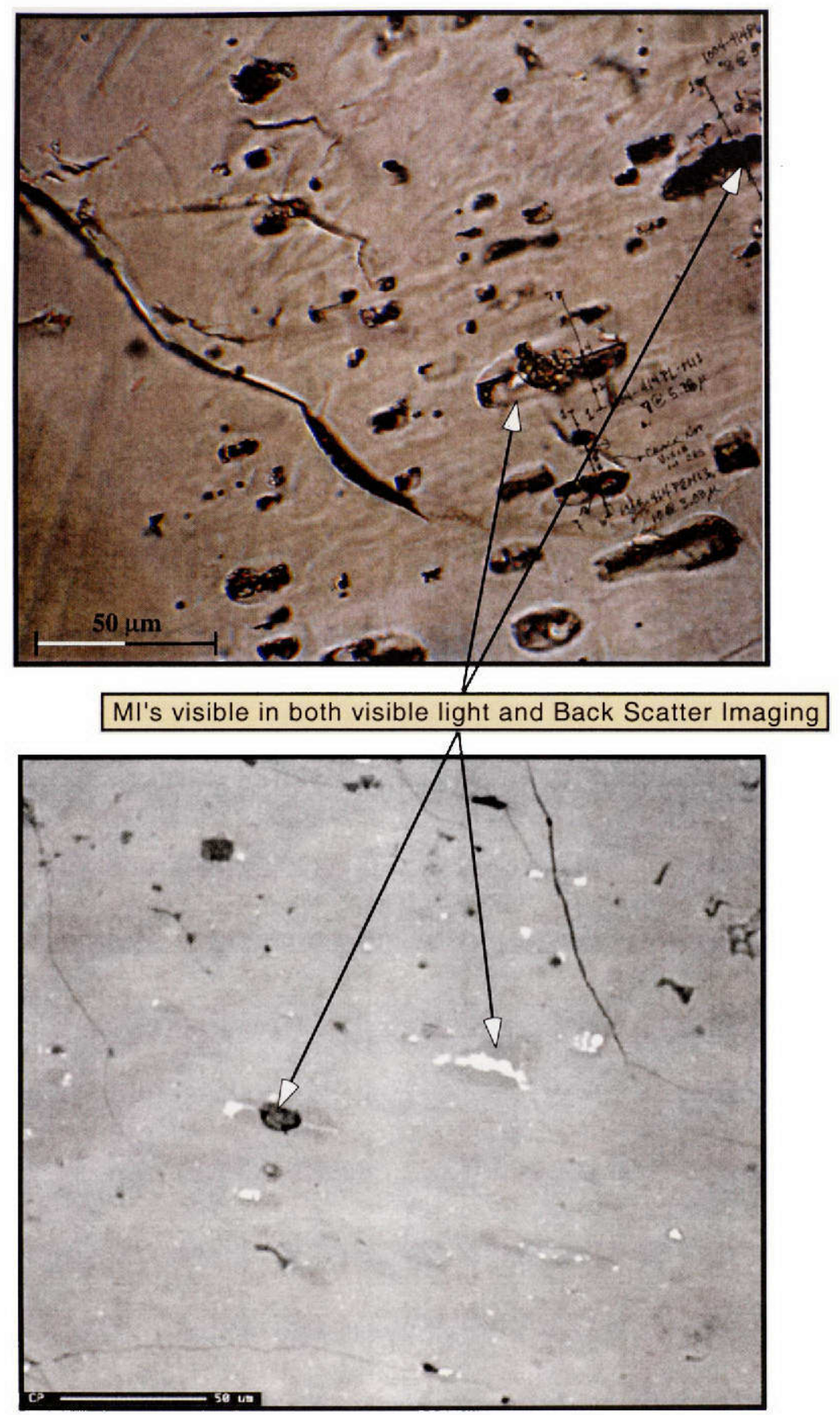

Figure 3-3: Comparison of transmitted light image and back scatter image (compositional mode) from EPMA. Sample 1004-414 from Smithsonian Institution. 


\section{CHAPTER 4: METHODS}

\subsection{Sample Preparation}

The eight samples used in this study were obtained from the Smithsonian Institution and from Florida International University archives. These samples represent block lava erupted from the Volcancito (DI-194 \& 1004-414) in 1869, the 1880 block lava eruption (M82-11, 1004-407 \& JT 91-68) and one scoriaceous sample from the cycle starting 1913 eruption (1004-421). Each of the samples (with the exception of DI-194 and JT 91-68) has been well studied and their whole rock analyses appear in Luhr \& Carmichael (1990). Thomas \& Draper (1991 field study) collected sample DI-194 from the lava flow of the Volcancito near the base of the "Plyon" adjacent to the caldera wall on the NE flank of Fuego de Colima. Sample JT 91-68 was collected from the base of the 1880 flow nearest to the caldera wall (adjacent to the 1913 deposit). All samples were cut into thin sections and the abundance of melt inclusions were inspected visually (Fig. 4-1). Because melt inclusions are abundant in plagioclase only these grains were chosen for rehomogenization experiments. Whole rock samples of DI-194 were crushed by hand and plagioclase (between 40-70 mesh) was separated with a Frantz Magnetic Separator. Plagioclase containing devitrified inclusions tend to have higher magnetic susceptibility than expected for pure plagioclase. Therefore, the lowest two magnetic fractions were used. Plagioclase grains were then hand picked and placed in a platinum boat and set aside for experimentation. Atmospheric re-heating experiments were conducted in a platinum wound $1 \mathrm{~atm}$. furnace (Fig. 4-2). Runs were conducted under atmospheric conditions and controlled oxygen fugacity $\left(f_{\mathrm{O}_{2}}\right)$ at various temperatures and 


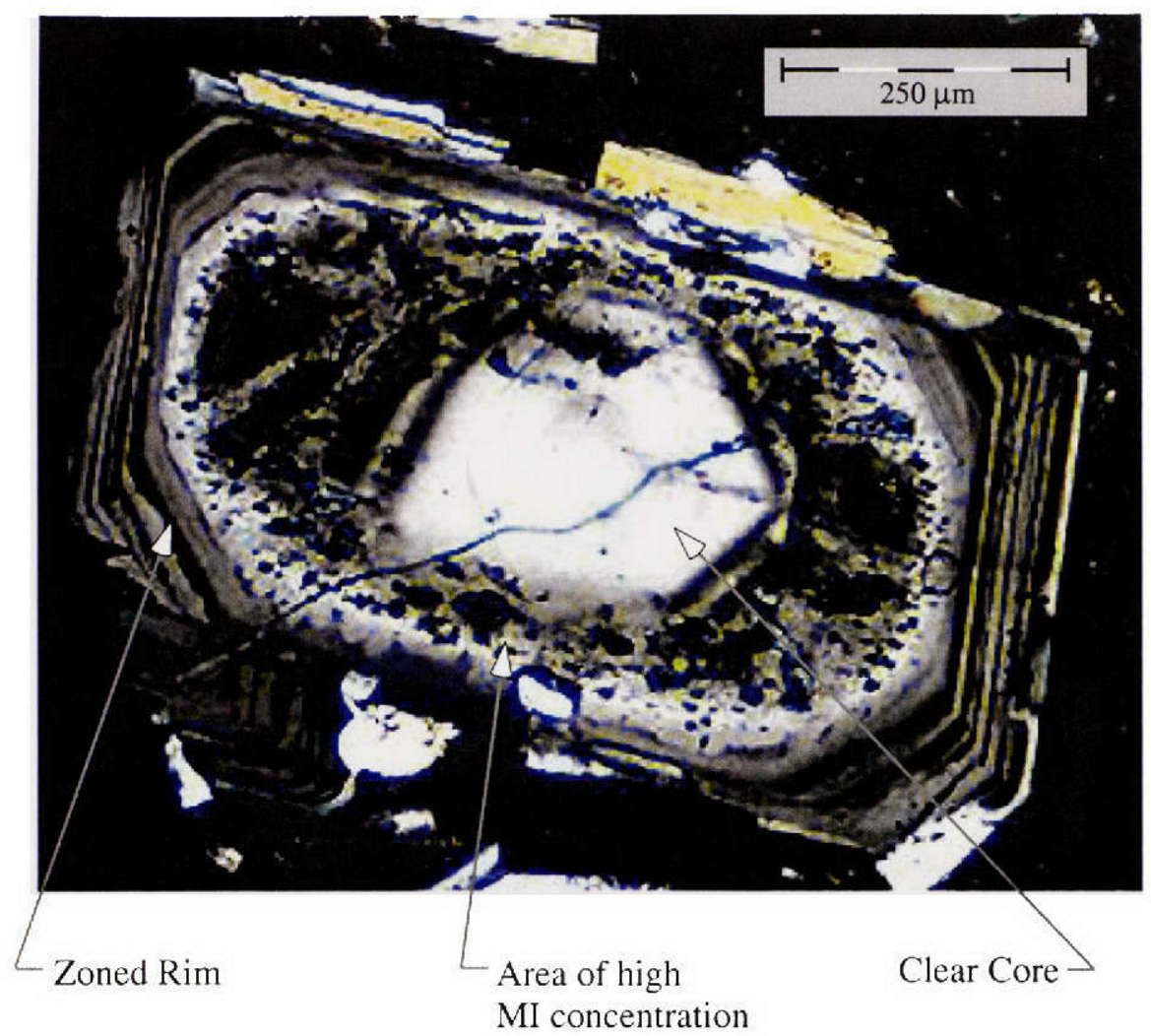

Figure 4-1: Sample DI-194 showing plagioclase with clear core, highly zoned rim and ring of melt inclusions (isotropic globules). Magnification is $100 \mathrm{x}$ in crossed polarized light 


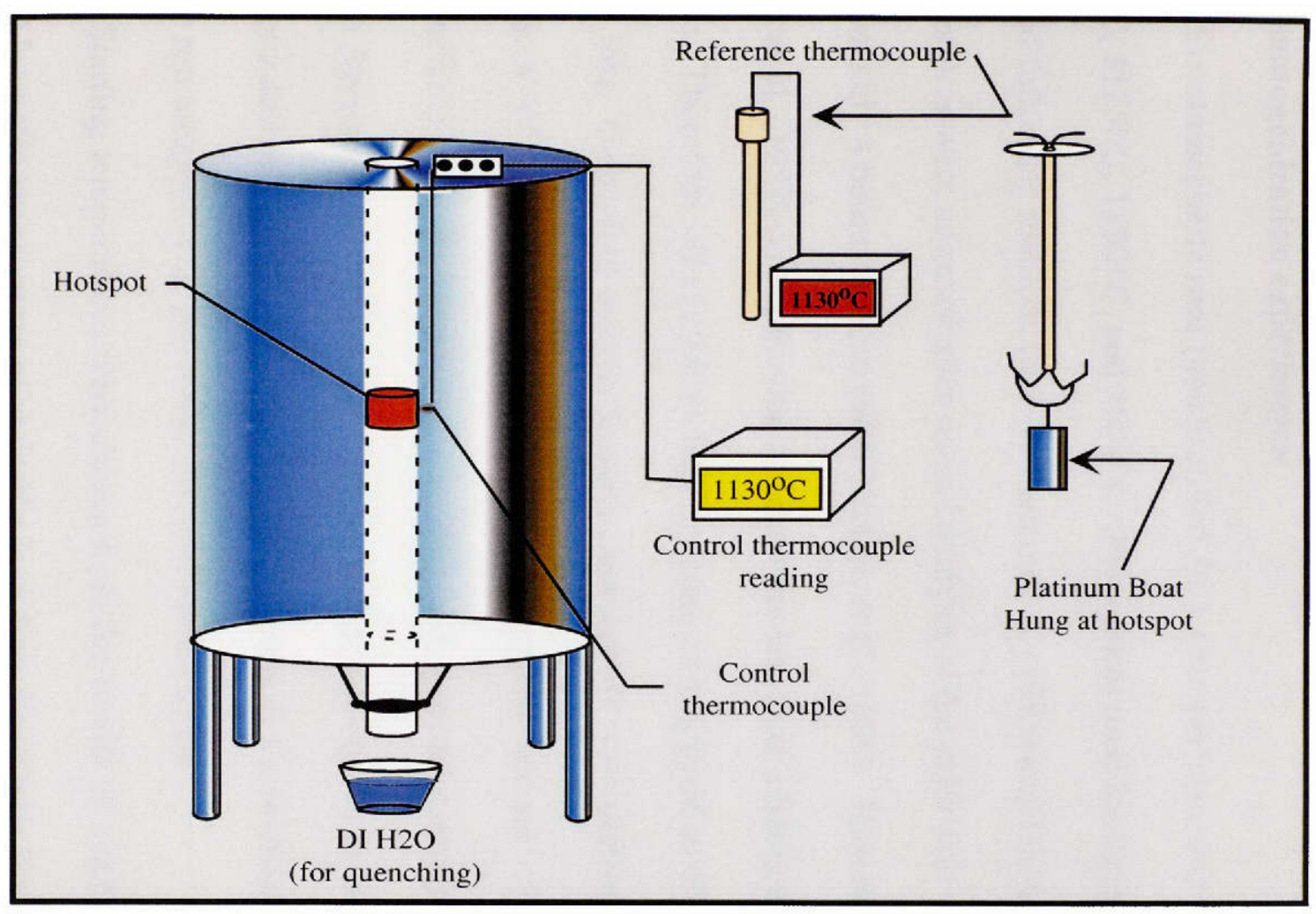

Figure 4-2 Design of a platinum-wound one-atmosphere gas-mixing furnace. (figure modeled after Gangopadhyay (1999) Masters Thesis). Figure not drawn to scale 
for different run duration. Oxygen fugacity was controlled using a mixture of purified $\mathrm{CO}_{2}-\mathrm{H}_{2}$ gas.

\subsection{Rehomogenization experiments}

Six atmospheric runs (uncontrolled $f_{\mathrm{o}_{2}}$ ) were performed at $1200^{\circ} \mathrm{C}, 1150^{\circ} \mathrm{C}$, $1140^{\circ} \mathrm{C}, 1125^{\circ} \mathrm{C}, 1100^{\circ} \mathrm{C}$, and $1000^{\circ} \mathrm{C}$. Procedures used for these experiments were modified following methods used by Sinton et al, (1993) and Dunbar and Hervig (1992). Temperatures were adjusted after optical analysis of the prior run. Initial runs are approximately 4 hours duration (after Nielsen et al., 1995). However in a later study, Nielsen et al. (1998) recommended run duration less than 2 hours to preserve initial water contents. Therefore, all controlled fugacity runs were limited to 40 minutes to avoid volatile loss. Controlled oxygen fugacity experiments were performed at descending intervals of $10^{\circ} \mathrm{C}$ starting at $1200^{\circ} \mathrm{C}$. Oxygen fugacity was set +1 Log unit above the NNO buffer (Fig. 4-3). Metered values of $\mathrm{CO}_{2}-\mathrm{H}_{2}$ gas and corresponding $f_{\mathrm{O}_{2}}$ values are given in Appendix A (Table A-1). The $f_{\mathrm{O}_{2}}$ buffer was chosen to closely match the conditions determined for the Colima magmas (Luhr \& Carmichael, 1980). Table 4-1 lists the run temperatures, $\mathrm{fO}_{2}$ conditions and run duration.

Starting temperatures were chosen from the wealth of available data on Colima lavas. Magmatic temperature of andesitic lava from Volcán de Colima have been reported to be between $880^{\circ} \mathrm{C}$ and $1200^{\circ} \mathrm{C}$ using pyroxene and Fe-Ti Oxide thermometry (Luhr \& Carmichael, 1980 \& Luhr, 1992). In general, Luhr \& Carmichael (1980) report temperatures for Colima andesites to be between $940^{\circ} \mathrm{C}$ and $1052^{\circ} \mathrm{C}$. Robin et al. (1990), concur with the above and report temperatures of crystallization of Colima's acidic 


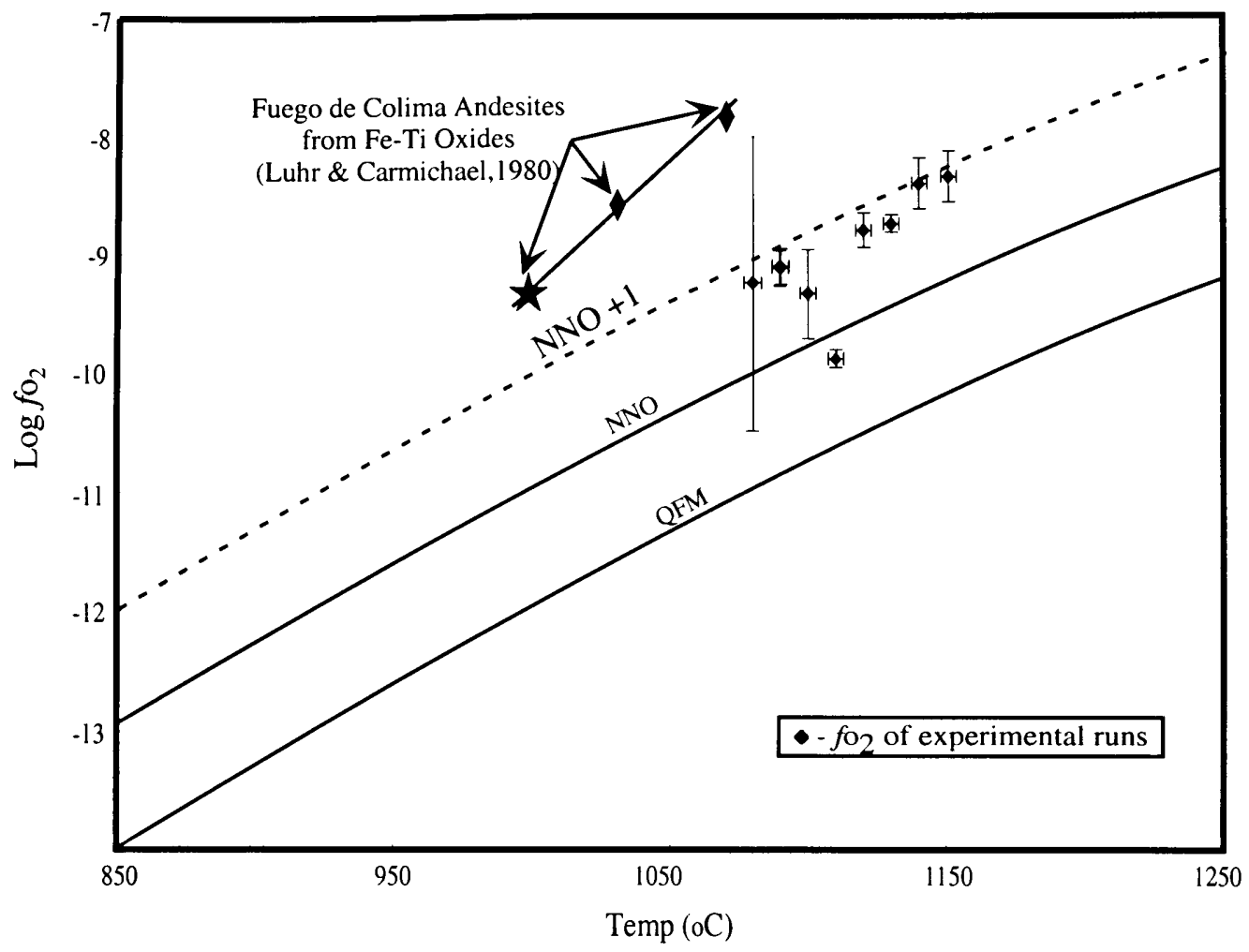

Figure 4-3: Plot of $\log$ fo2 versus tempreture. Experimental runs and Colima lavas are shown relative to QFM and NNO buffers. Experimental runs plot approximately at $\mathrm{NNO}+1$ (Dashed Line).

\begin{tabular}{|lccc|}
\hline Run & $\mathrm{T}\left({ }^{\circ} \mathrm{C}\right)$ & $f \circ 2$ & Duration (min) \\
\hline DI-194 CF 1 & $1140 \pm 1$ & $-8.41 \pm 0.21$ & 40 \\
DI-194 CF 1b & $1150 \pm 1$ & $-8.35 \pm 0.23$ & 31 \\
DI-194 CF 1c & $1150 \pm 1$ & $-8.35 \pm 0.23$ & 64 \\
DI 194 CF 2 & $1130 \pm 1$ & $-8.75 \pm 0.06$ & 40 \\
DI-194 CF 3 & $1120 \pm 1$ & $-8.81 \pm 0.15$ & 40 \\
DI-194 CF 4 & $1110 \pm 1$ & $-9.89 \pm 0.01$ & 40 \\
DI-194 CF 5 & $1100 \pm 1$ & $-9.34 \pm 0.35$ & 45 \\
DI-194 CF 6 & $1090 \pm 1$ & $-9.11 \pm 0.11$ & 40 \\
DI-194 CF 6b & $1090 \pm 1$ & $-9.12 \pm 0.04$ & 62 \\
DI-194 CF 7 & $1080 \pm 1$ & $-9.25 \pm 0.18$ & 45 \\
DI-194 CF 7b & $1080 \pm 1$ & $-9.24 \pm 1.25$ & 62 \\
\hline
\end{tabular}

Table 4-1: Temperature, $f \circ 2$ and run duration for all controled fugacity, 1 atm. experiments. 
andesites, between $918^{\circ} \mathrm{C}$ and $982^{\circ} \mathrm{C}$ based on pyroxene thermometry and $1040^{\circ} \mathrm{C}$ $1120^{\circ} \mathrm{C}$ using Fe-Ti Oxide thermometry. Accordingly, the run temperatures were chosen to be $>900^{\circ} \mathrm{C}$ and $<1200^{\circ} \mathrm{C}$. Rapid quenching of the runs $(<0.5 \mathrm{sec}$.) in distilled water ensured homogenization of the glass in the MI's. However, vapor bubbles were always observed to be present.

Calibration runs were conducted prior to each set of experiments. Temperature during calibration was measured using an internal $\mathrm{Pt}^{-\mathrm{Rh}_{5}}$ thermocouple and external, Oxytrol Systems reference thermocouple. The calibration procedure determines the "hot spot" and the temperature where control and reference thermocouples are equal. This is accomplished by moving the reference thermocouple up, through the center of the furnace tube. This procedure determines temperature gradients within the furnace (Gangopadhyay, Masters Thesis, 2000). The external thermocouple was plugged into a voltmeter to simultaneously measure $f_{\mathrm{o}_{2}}$. Final values for $f_{\mathrm{O}_{2}}$ were determined according to the Nernst equation (Appendix A). Finally, the liquidus temperature of pure diopside $\left(1391.5^{\circ} \mathrm{C}\right)$ was used to calibrate exact temperature. Temperature variation in the furnace was found to be precise to $\pm 1^{\circ} \mathrm{C}$. Appendix A contains data on the calibration runs and calculation of oxygen fugacity.

Experimental runs were inspected under a petrographic microscope and aliquots separated for mounting in epoxy. Plagioclase grains were randomly chosen for mounting to avoid sampling bias. Grains were then mounted on petrographic slides using petropoxy and polished to expose MI's. Procedures for exposing melt inclusions were difficult and sometimes resulted in breaching or destroying the MI itself. One method commonly used by other investigators is double polishing the phenocryst to expose the 
MI on both sides. This method has been helpful in obtaining $\mathrm{H}_{2} \mathrm{O}$ and $\mathrm{CO}_{2}$ analysis using FTIR spectroscopy (Dixon \& Clague 2001, Gioncada et al. 1998, Vogel \& Aines 1996). Nielsen, et al (1998) cautioned that double polishing is an arduous, time consuming task that sometimes results in micro-fractures thereby breaching the MI. Therefore Colima samples were polished to expose MI's on one side only. All run products were analyzed for major elements, trace elements and water as outlined below.

\subsection{Microprobe analysis}

Melt inclusions were imaged and analyzed using a JEOL $8900 \mathrm{R}$ electron microprobe at Florida International University's Florida Center for Analytical Electron Microscopy. Analytical conditions on the JEOL $8900 \mathrm{R}$ were $15 \mathrm{KeV}$ at $20 \mathrm{nA}$ beam current, using a point mode beam. Count times for major elements are 10 seconds $(\mathrm{Na}$, $\mathrm{K}, \mathrm{Ca}, \mathrm{Mg}, \mathrm{Fe}, \mathrm{Ti}, \mathrm{Mn} \& \mathrm{Al}$ ) and 20 seconds for silicon. Standard measurements were taken on the SPI-2 standard block. The standards used on SPI-2 were obsidian glass, diopside, albite, magnetite and rhodenite (see Appendix B for standard compositions). Standard compositions were gathered at least bi-weekly (due to current fluctuations, filament changes or consistently poor totals on host materials) and elements were repeaked prior to daily analysis. Because volatility of $\mathrm{Na}$ in natural glasses tends to be quite high (Nielsen \& Sigurdsson, 1981), this element was analyzed for 10 seconds during the first beam pass using a high-count crystal (PETH). Line scans were performed at $\sim 5 \mu \mathrm{m}$ intervals. Point analyses were performed after the line scans to confirm the chemistry of the MI's. Subsequent spots were located in compositional backscatter mode and are visually identical to the initial spot. 
Sodium loss was measured for various beam diameters using obsidian glass standard from SPI-2 at $15 \mathrm{kV}$ and $20 \mathrm{nA}$. Each beam diameter was measured by fluorescence on the benitolite and quartz standards. Beam diameter measured $5.8 \mu \mathrm{m}$ for point mode and $22.8 \mu \mathrm{m}$ for a beam diameter of 50 . However, due to the distinct fluorescence of the different materials this measurement can be as much as $50 \%$ in error (Fig. 4-4). Therefore, the smallest beam sizes have $\mathrm{a} \pm 3 \mu \mathrm{m}$ error while the largest beam diameter is $\pm 7.5 \mu \mathrm{m}$. These analyses reveal considerable Na loss (1.5 - $2.0 \mathrm{wt} \%)$ during the first 10 seconds of analysis using a point beam $(5 \pm 3 \mu \mathrm{m})$ (Fig 4-4). Larger beam sizes (e.g., beam diameter $=20 \& 50$ ) tend to minimize Na loss in the obsidian glass but because of the large error associated with the measured beam size, these beam sizes are too large for analysis of MI's smaller than $50 \mu \mathrm{m}$ in diameter.

$\mathrm{Na}$ loss was also measured as a function of time in obsidian glass (Fig. 4-5). After 10 seconds of analysis count rates drop to $1 / 2$ the initial count rate observed at 2 seconds. However, because the beam needs 2 seconds in order to stabilize prior to the time when counting begins, this drop may reflect loss after four seconds. If beam stabilization is considered to have an effect on the sodium loss (as it should), then total beam time of 4 seconds corresponds to a loss of only $1 / 4$ of the counts. It was found that $\mathrm{Na}$ loss in the obsidian glass was deficient by $0.9 \mathrm{wt} \%$ (if 4 second times are considered) and $1.8 \%$ (if 2 second times are considered). We expect these values to be intermediate because the beam strength fluctuates between $20 \mathrm{nA}$ and zero almost randomly during stabilization. Thus, some sodium loss is expected, but not as much as if the beam is stable for the additional 2 seconds. Furthermore, the obsidian glass is closest standard to the MI's in composition and thus we assume a similar loss of $\mathrm{Na}_{2} \mathrm{O}$ in the melt inclusions. 

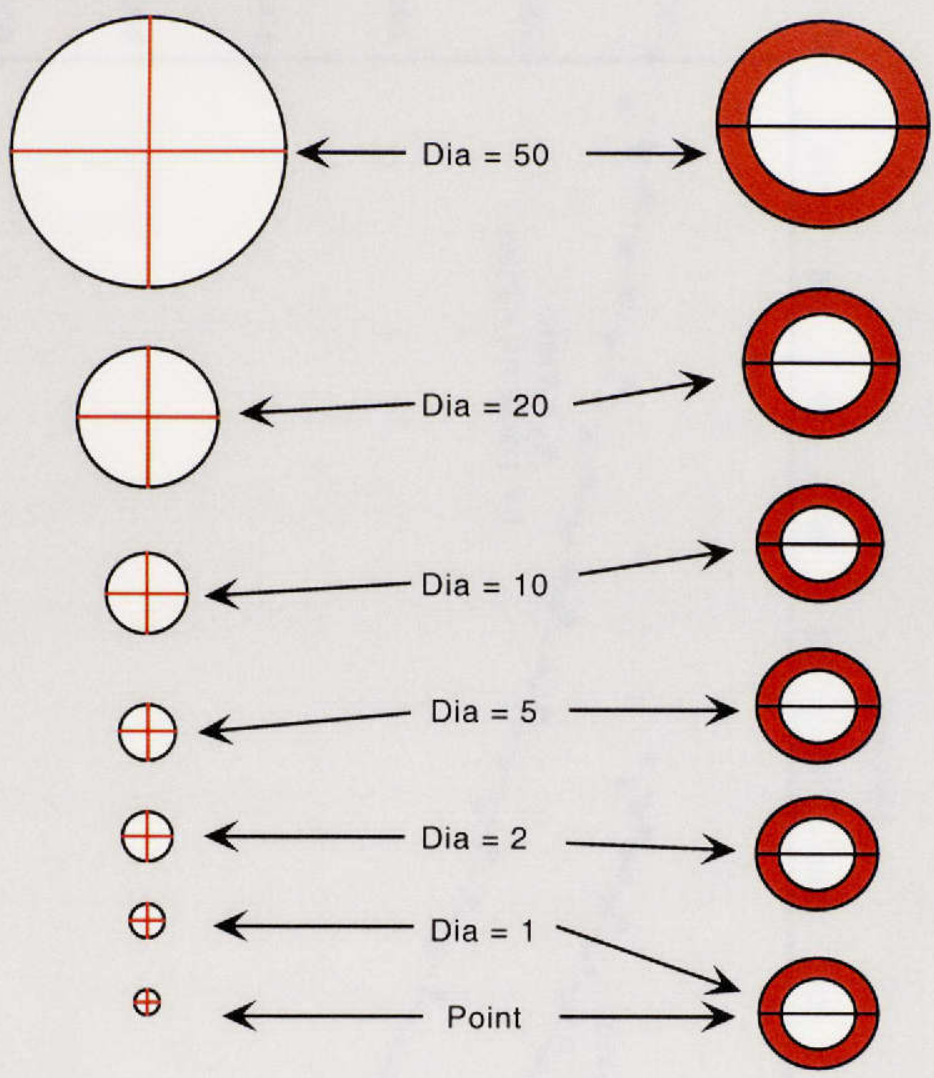

Spot Size

Measured form Quartz

Flourescence

$15 \mathrm{kV} 20 \mathrm{nA}$

$300 \mu \mathrm{m}$ apature

Spot Size

Measured form Benitolite

Flourescence

$15 \mathrm{kV} 20 \mathrm{nA}$

$300 \mu \mathrm{m}$ apature

Figure 4-4: Probe diameter measured from the flourescenec of quartz and benitolite. Outer circles on benitolite represent area of decreasing brightness observed during measurement. Scale bar is shown for reference 


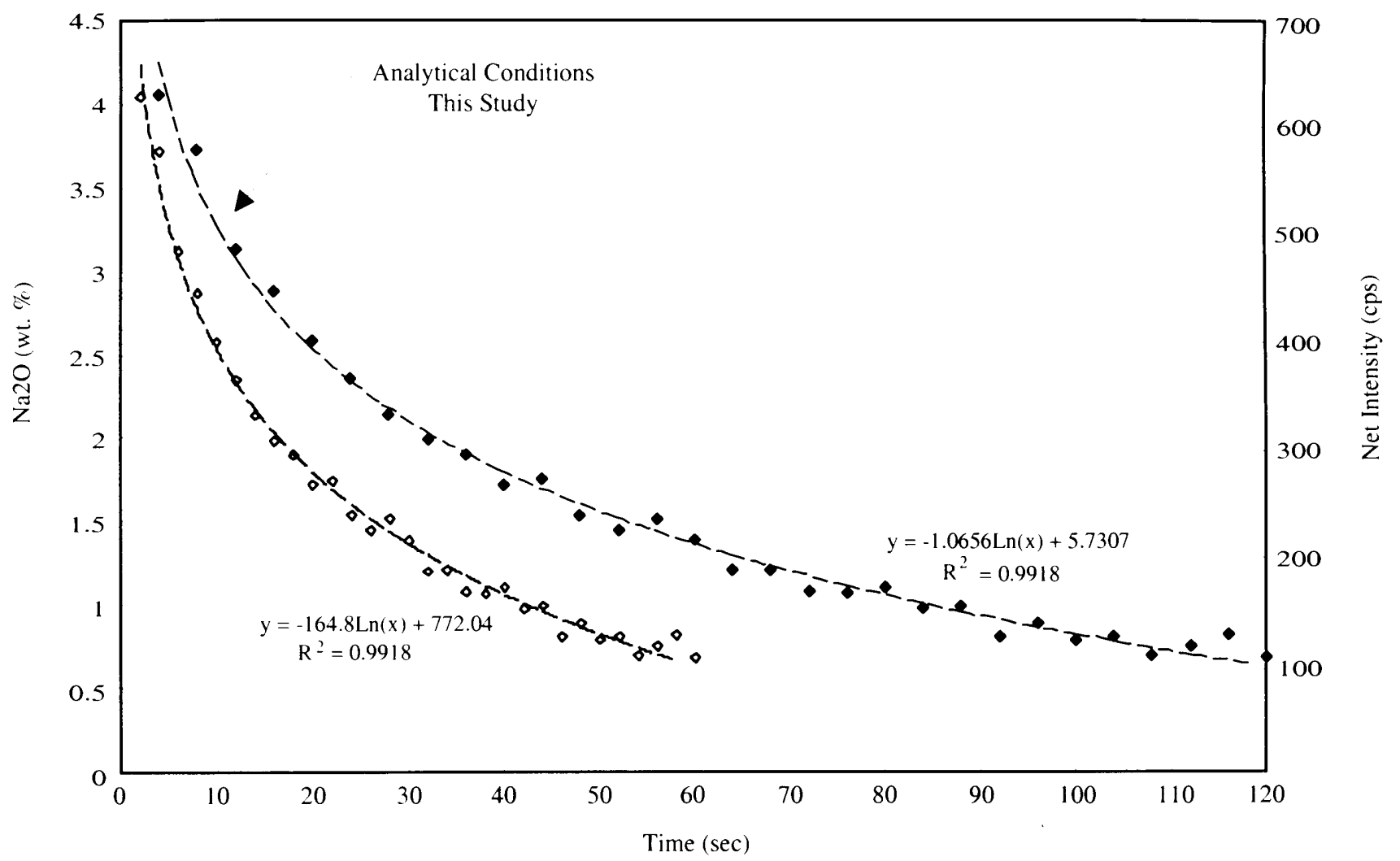

Figure 4-5: Sodium loss in obsidian as a function of time. Analytical conditions are $15 \mathrm{kV}$ and $20 \mathrm{nA}$ using point beam mode. Open symbols represent sodium loss experienced when only counting times are taken into account. Closed simbols represent total beam time. Values used for sodium addition are intermediate between 2 and 4 secondcurves at 10 seconds (dashed line). 
Therefore all sodium values reported reflect initial pass values using the point beam and were corrected for sodium loss using the $\mathrm{Na}_{2} \mathrm{O}$ loss calibration curves. The extent of correction was the median value observed to be lost in obsidian after 10 seconds (e.g., $1.35 \%)$.

\subsection{Ion Probe Analysis}

Measurements of trace elements and $\mathrm{H}_{2} \mathrm{O}$ were made on a Cameca IMS $3 \mathrm{f}$ Ion Probe at Arizona State University. Analytical conditions were outlined in detail by Hervig \& Dunbar (1992); Dunbar \& Hervig (1992) and Hervig et al. (1989). One inch, carbon coated, petrographic slides, analyzed earlier by EPMA, were placed in a high vacuum chamber where they are bombarded with negative ${ }^{16} \mathrm{O}$ ions. Although gold coats are preferred for ion probe analysis carbon coats did not seem to hinder analysis. Carbon coats however do increase the sputtering time necessary for ion beam penetration and location of MI's. Primary accelerating voltage on the Cameca $3 \mathrm{f}$ was $-12.55 \mathrm{kV}$, secondary accelerating voltage was $4500 \mathrm{~V}$ and arc current was fixed at $80 \mathrm{~mA}$. A $75 \mathrm{~V}$ offset was used to limit molecular interference. Standard measurements for trace elements were taken on the NIST 610. Standard measurements for water were acquired from the M3N and M6N rhyolite standards at ASU. Calibration curves (Fig. 4-6) matched those calculated in Ihinger et al. (1994). ${ }^{30} \mathrm{Si}$ was used as an internal standard and was measured before and after element acquisition. Analytical uncertainty is $<10 \%$ for trace elements and $\pm 0.5 \mathrm{wt} \%$ for $\mathrm{H}_{2} \mathrm{O}$ (Hervig et al., 1989). 


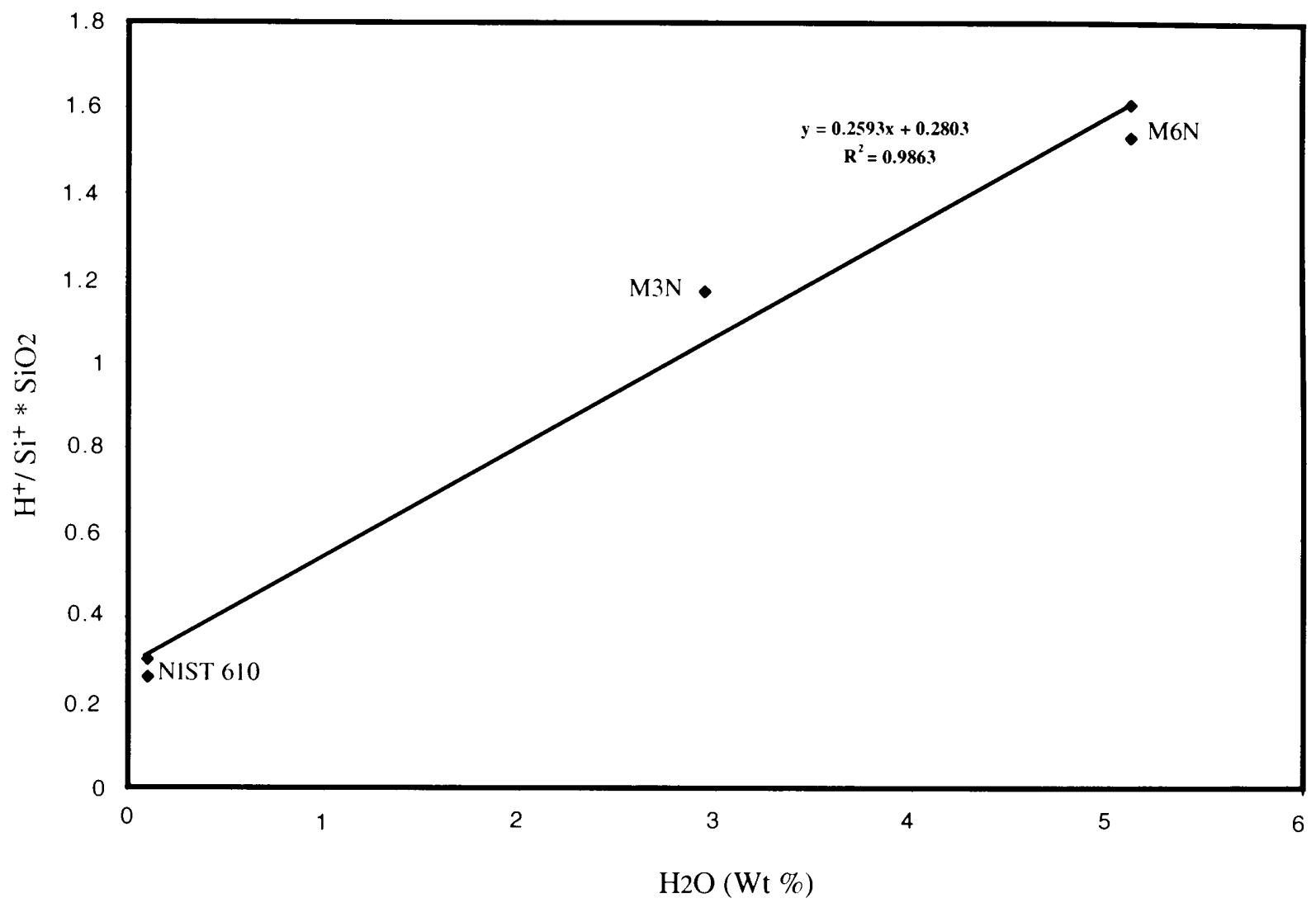

Figure 4-6: H2O calibration graph for NIST 610, M3N and M6N standards 


\subsection{Laser Ablation ICPMS}

An attempt was made to obtain trace element data using laser ablation, induced coupled plasma mass spectrometry (LA-ICP-MS). This technique is currently being developed for use with melt inclusions and has been successfully applied to analysis of natural glasses (Pearce et al., 1999; Schroeder, et al., 1998) and phenocryst analysis (Davidson et al., 2001; Christensen et al., 1995). Some advantages of using LA-ICP-MS are presented in the following section. First, sample preparation/analysis time for LAICP-MS is reduced from days or even weeks to hours as compared with standard microdrilling techniques followed by isotope dilution mass spectrometry. In a comparative study between TIMS and LA-ICP-MS, Davidson et al. (2001), reports that one day of analysis using LA-ICP-MS yielded the same number of results as years of analyses performed using the microdrilling-TIMS method. Another advantage of LAICP-MS is that it can be used to analyze very small areas $(\sim 5 \mu \mathrm{m}$ diameter spot $)$. By varying the power of the laser, the depth of the pit can also be controlled to high precision (Schroeder, et al., 1998; Pearce, et al., 1999). This is very advantageous when studying melt inclusions because most melt inclusions measure $25-100 \mu \mathrm{m}$ in length and $10-50 \mu \mathrm{m}$ in width and depth.

One sample (a hornblende from 1004-421) was ablated with a Cetac LSX 200 Nd:YAG Laser operating in the UV spectra range (266nm) using methods outlined by (Davidson et al., 2001). Analysis of the hornblende was used as a test for accuracy of concentrations determined by LA-ICP-MS (compositions of hornblende has been well studied, Luhr \& Carmichael, 1980) and to determine proper laser power needed to produce pit sizes no larger than chosen MI's. Power was varied from $100 \%$ at a $20 \mathrm{~Hz}$ 
repetition rate to $25 \%$ at $10 \mathrm{~Hz}$ and two pits were created measuring $\sim 100 \mu \mathrm{m}$ and $30 \mu \mathrm{m}$ respectively. Ablated material was transferred to the HP 4500 Quadrupole Mass Spectrometer via a transfer tube in an Argon atmosphere. Calibration was performed using the NIST SRM 612 and 610 standards. Results for these two "test" analyses yielded grossly inaccurate results. Hornblende was found to contain $1150 \mathrm{ppm}$ of La (compared to 2-3 ppm reported by Luhr \& Carmichael, 1980) in spite of the fact that the signal (in counts per second) was identical to the blank (purified Ar gas). Similar results were found for all other elements analyzed. Therefore, this strategy was abandoned (for the time being) and no further discussion of LA-ICP-MS analysis is provided. 


\section{CHAPTER 5: PETROGRAPHY}

\subsection{Whole Rock Samples}

Samples from the eruptive period 1869-1913 were inspected in thin section using transmitted and reflected light microscopy. As described earlier, all samples contain zoned plagioclase phenocrysts, with varying amounts of orthopyroxene (opx) clinopyroxene (cpx) and hornblende. Groundmass typically consist of $>50 \%$ microphenocrysts of plagioclase. A small but significant amount of cpx, opx and iron-titanium oxide phase is also present throughout the groundmass (analyzed by Luhr \& Carmichael, 1980 as Ti-magnetite). Appendix $\mathrm{C}$ describes these samples in detail and gives modal proportions phenocrysts and groundmass.

Petrographic analysis also reveals that hornblende is the most variable component. Modal percentages of amphibole tend to decrease in the years preceding the major eruption of 1913. Furthermore, dark oxidation rims around amphibole phenocrysts were observed to thicken towards the end of the magmatic cycle (e.g., in 1890 lava). Samples from the 1869 lava flow of the Volcancito (DI-194, 1004-407 \& 1004-414) contain abundant hornblende with distinct oxidation rims (Fig. 5-1). These oxidation rims are a result of reaction breakdown of hornblende (Moore \& Carmichael 1998; Devine \& Rutherford, 1998; Rutherford \& Hill, 1993). Oxidation rims were found to vary between $7 \mu \mathrm{m}$ and $25 \mu \mathrm{m}$ in thickness and average $18 \mu \mathrm{m}$ in samples $1004-407 \&$ DI194. It should also be noted that observed rim thickness is greater when the crystal is viewed parallel to the crystallographic $\mathrm{c}$ axis than if viewed perpendicular to the $\mathrm{c}$ axis. Rutherford \& Hill (1993) recommend measuring the thickness of the rim perpendicular to 


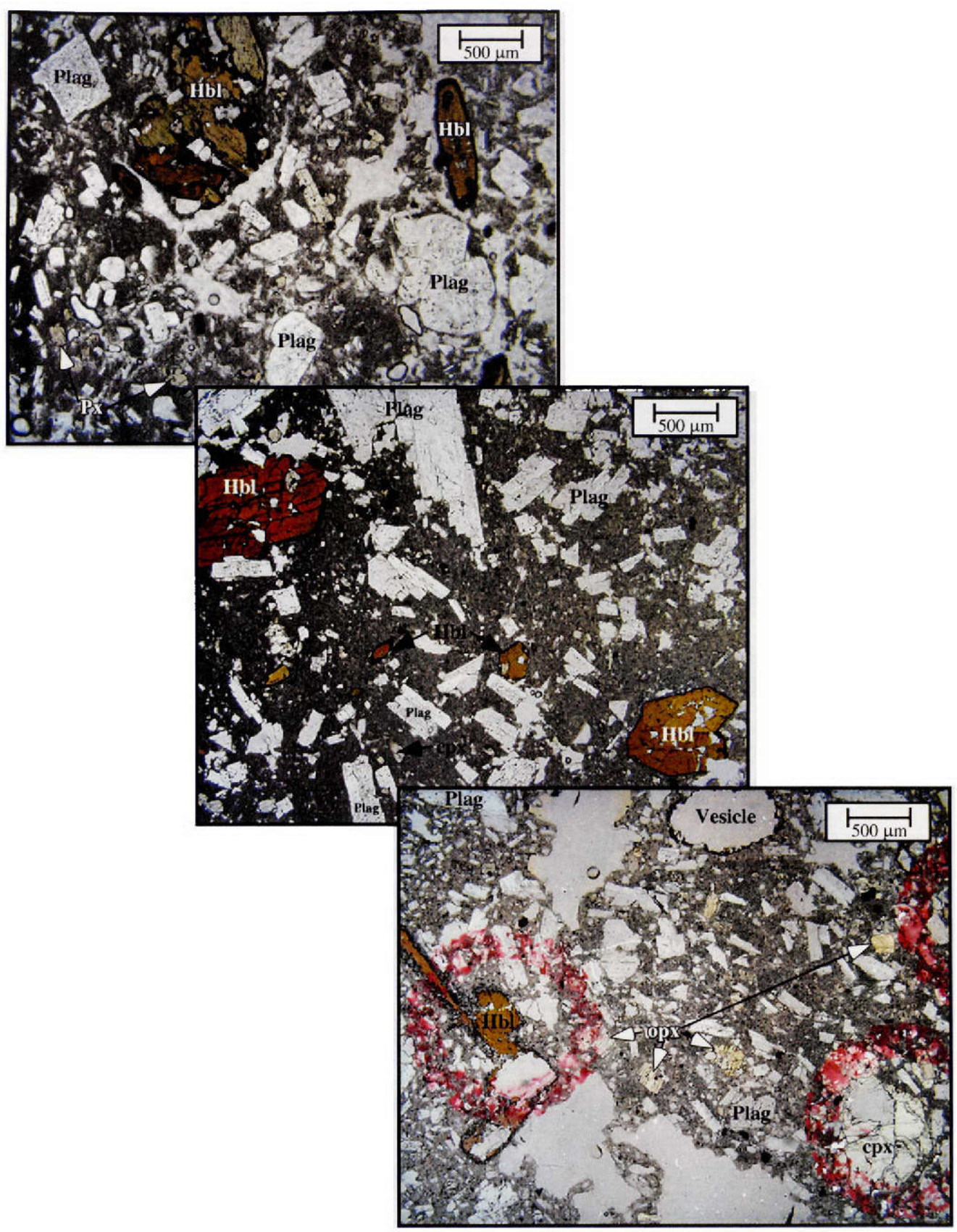

Figure 5-1: Photomicrograph of samples DI-194 (top), 1004-407 (center) \& 1004-414 (bottom) shown in plane polarized light. All are oxyhornblende rich. Rims measure 7 to $25 \mu \mathrm{m}$ and are larger parallel to thecrystallographic c-axis. Magnification is $15 \mathrm{x}$. 

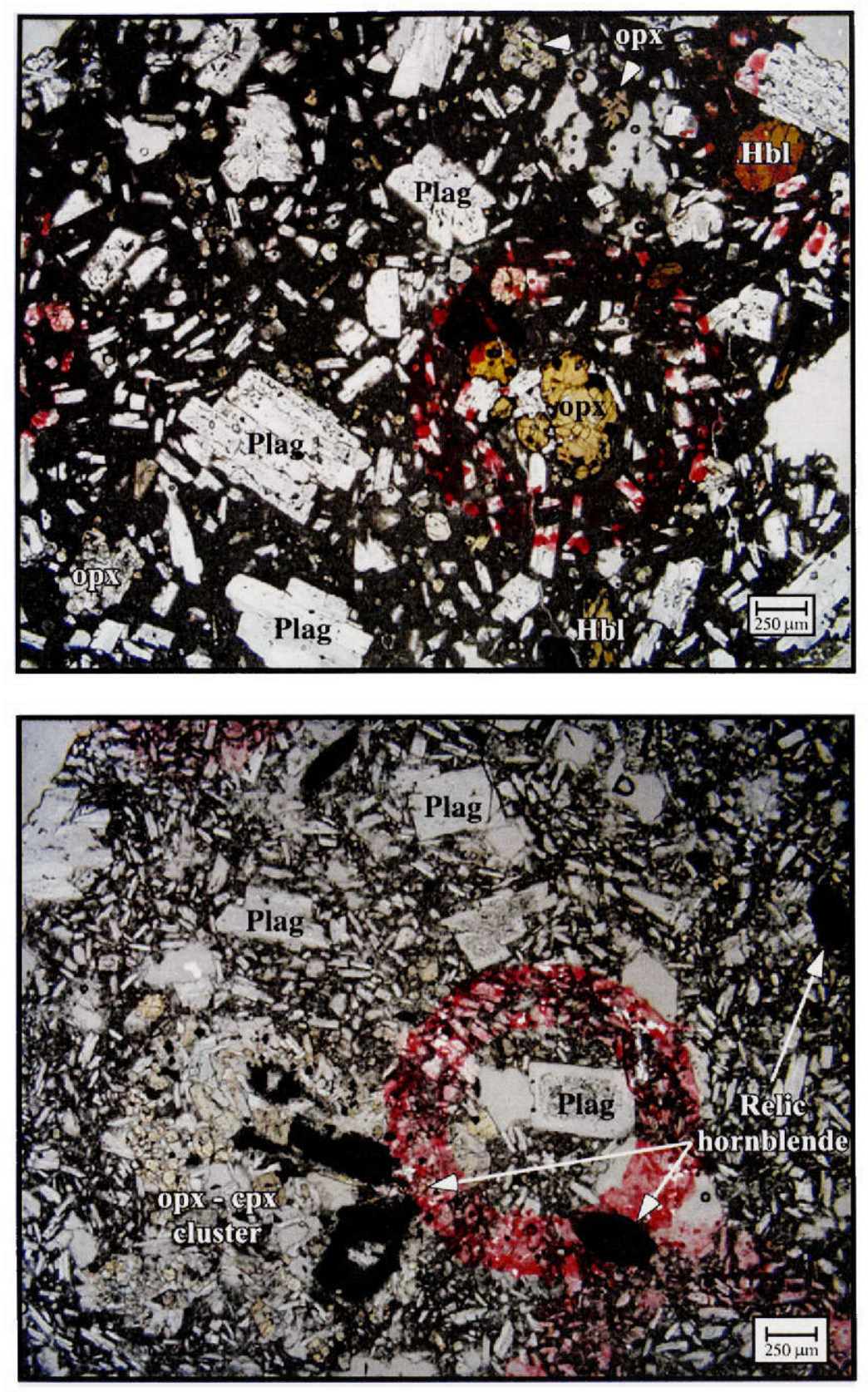

Figure 5-2: Photomicrograph of sample M82-11 Top and JT 91-68 Bottom, shown in plane polarized light. Samples range from hornblende poor to hornblende absent. Hornblende rims measure 8 to $10 \mu \mathrm{m}$ in M82-11 and $\sim 200 \mu \mathrm{m}$ in JT 91-68. Interior of red ring is $\sim 1 \mathrm{~mm}$ in diameter. Magnification is $15 x$. 

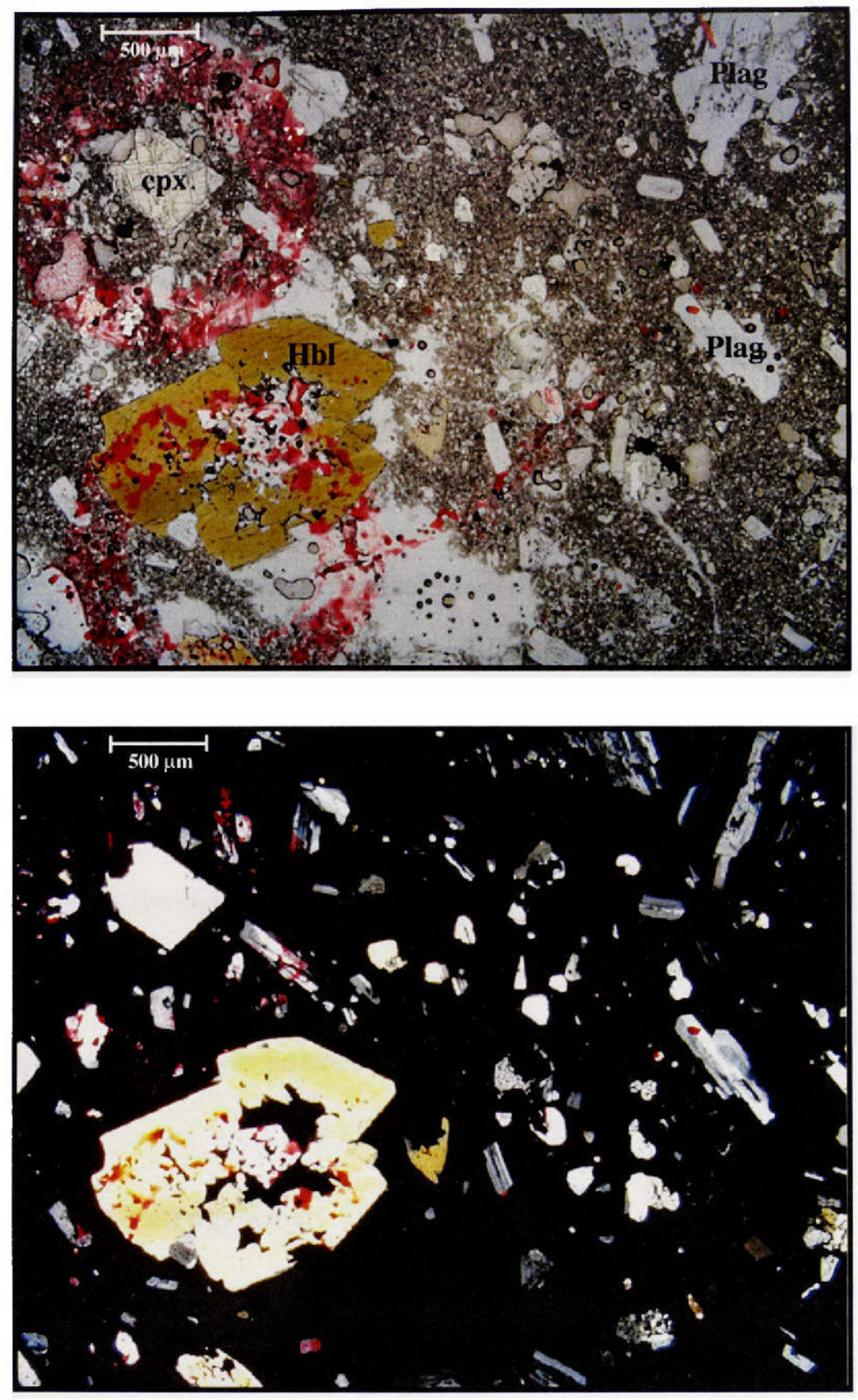

Figure 5-3: Photomicrograph of sample 1004-421 shown in plane and crossed polarized light. Large hornblende and clinopyroxene phenocrysts appear at left. Interior of red circle is $\sim 1 \mathrm{~mm}$ in diameter. Magnification is $15 x$. 
the $\mathrm{c}$ axis, although they observed no noticeable difference with respect to orientation in the hornblende rims measured from Mt. St. Helens (MSH) and Soufriere Hills. Rim thickness in sample 1004-414 is much larger and measures $80 \mu \mathrm{m}$ to $100 \mu \mathrm{m}$ when viewed either perpendicular or parallel to the c axis. Inner opacite rims on these phenocrysts are comparable in size $(\sim 20 \mu \mathrm{m})$ to its smaller rimed counterparts mentioned above. Sample M82-11 (from the 1880 block lava flow) contains a minor amount of hornblende. Hornblende rims in this sample measure 8-10 $\mu \mathrm{m}$. Sample JT 91-68 (also reported to be from 1880 block lava, Thomas \& Draper, field study, 1991) contains oxidized relics of amphibole distinguishable only by their original crystal form (Fig. 5-2). Oxidation rims in sample JT 91-68 were measured from the center of the relic to its edge and were found to be $200 \pm 25 \mu \mathrm{m}$ (across basal sections). We must assume that because the relic hornblende retains its original form, the farthest extent of the rim is equal to the edge of the original hornblende phenocryst. Therefore, measurements in this sample may be regarded as the minimal size of the reaction rim. The 1913 scoria sample is rich in amphibole that does not have any oxidation rims (Fig. 5-3).

\subsection{Melt Inclusion Petrography}

As described in numerous papers, most plagioclase crystals contain reacted cores (Luhr and Carmichael, 1980, 1989, Luhr, 1992, Robin, et al., 1990). Melt inclusions commonly occur within these cores (Fig. 5-4). A much smaller population of MI's occurs within the rims. In general, core MI's are 50-150 $\mu \mathrm{m}$ in diameter while rim MI's are typically smaller $(20-75 \mu \mathrm{m}$ in diameter). The shapes of MI's are highly variable and 
range from rectangular to round to polygonal (Fig. 5-5). Unhomogenized, plagioclase hosted MI's are often brown and contain post entrapment crystals (Fig. 5-6).

Experimentally rehomogenized MI's, hosted by plagioclase, have been optically analyzed prior to EPMA and ion probe analysis. After heating, MI's usually become vitreous and no significant change in shape is observed (Fig. 5-7). Most rehomogenized MI's contain at least one vapor bubble and in rare instances can contain 3 or more vapor bubbles (Fig. 5-8) (multiple vapor bubbles are generally limited to large MI's heated to lower temperatures). Secondary crystals can be seen in MI's rehomogenized under lower temperature (Fig. 5-9). Optically the secondary crystals are square, light green in color and show low birefringence ( $\delta$ was difficult to estimate due to the small size). It should also be noted that some crystals contain both vitrified and devitrified inclusions (Fig. 5$10)$.

Hornblende and pyroxene also contain melt inclusions. These MI's are quite different than those found in plagioclase. MI's in hornblende and pyroxene are vitreous. Their shape is usually diamond to oval, and they typically contain one vapor bubble (Fig. 5-11). Inclusions in pyroxene and hornblende are rare and occur almost anywhere in the host crystal with no apparent spatial preference. 


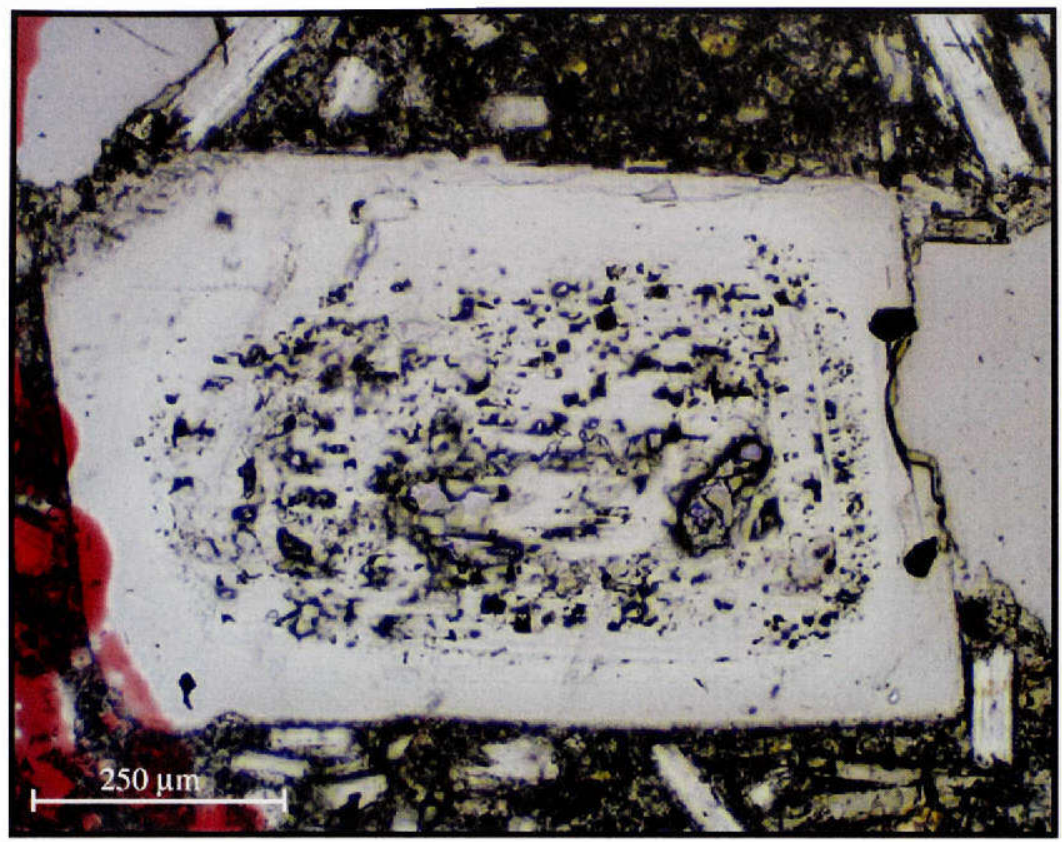

Figure 5-4: Photomicrograph of plagioclase with a high concentration of melt inclusions in its core from sample Col-9D. Shown in plane polarized light, magnification $100 x$.

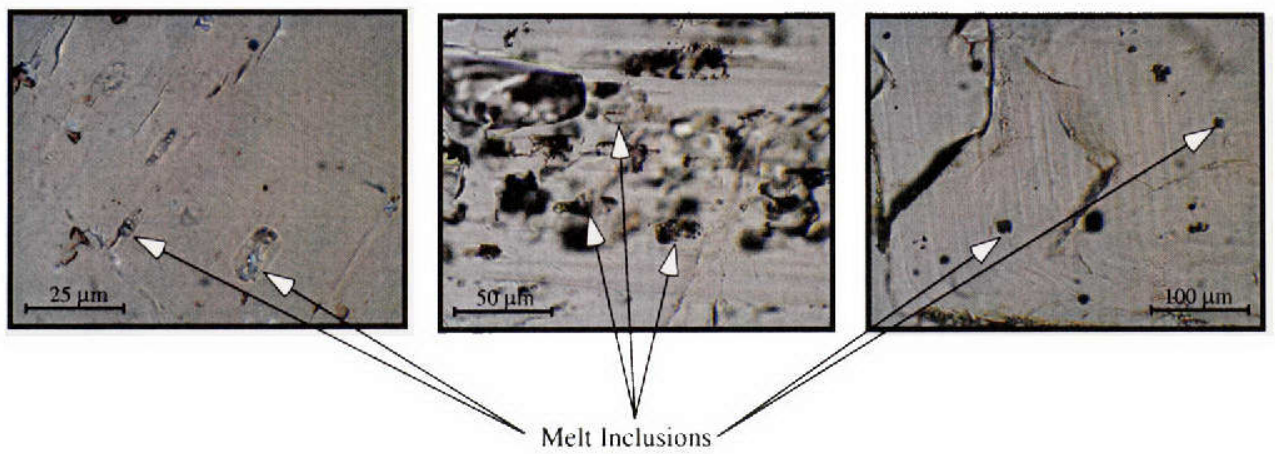

Figure 5-5: Photomicrographs of plagioclase melt inclusions.

Shapes vary from rectangular (left) to oval (right) to polygonal (center). Shown in plane polarized light, magnification is $400 \mathrm{x}$. 


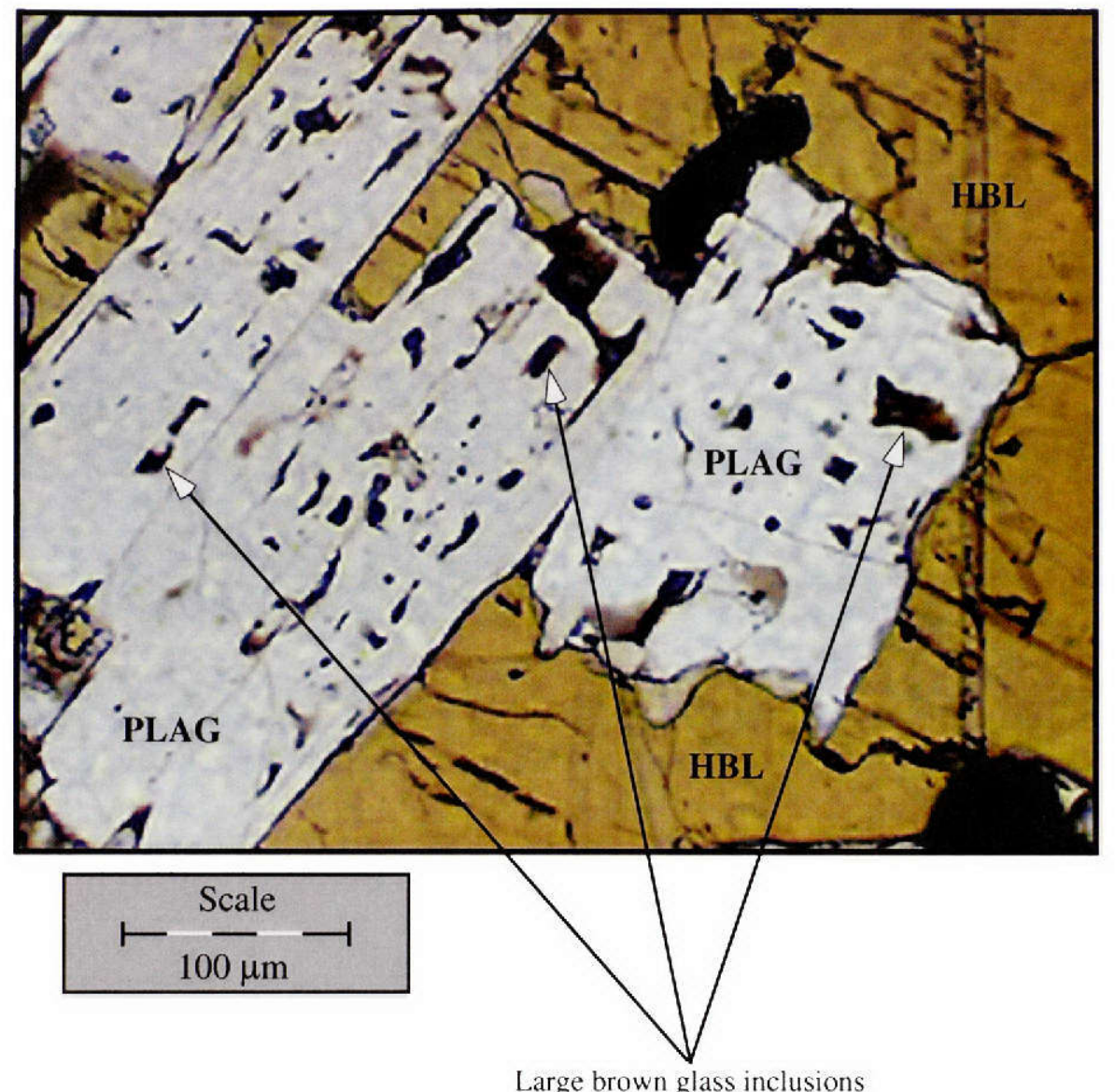

Figure 5-6: Photomicrograph of brown de-vitrified inclusions in plagioclase from sample 1004-421. Photo was enhanced from 100x picture. Scale bar shown is for reference. 


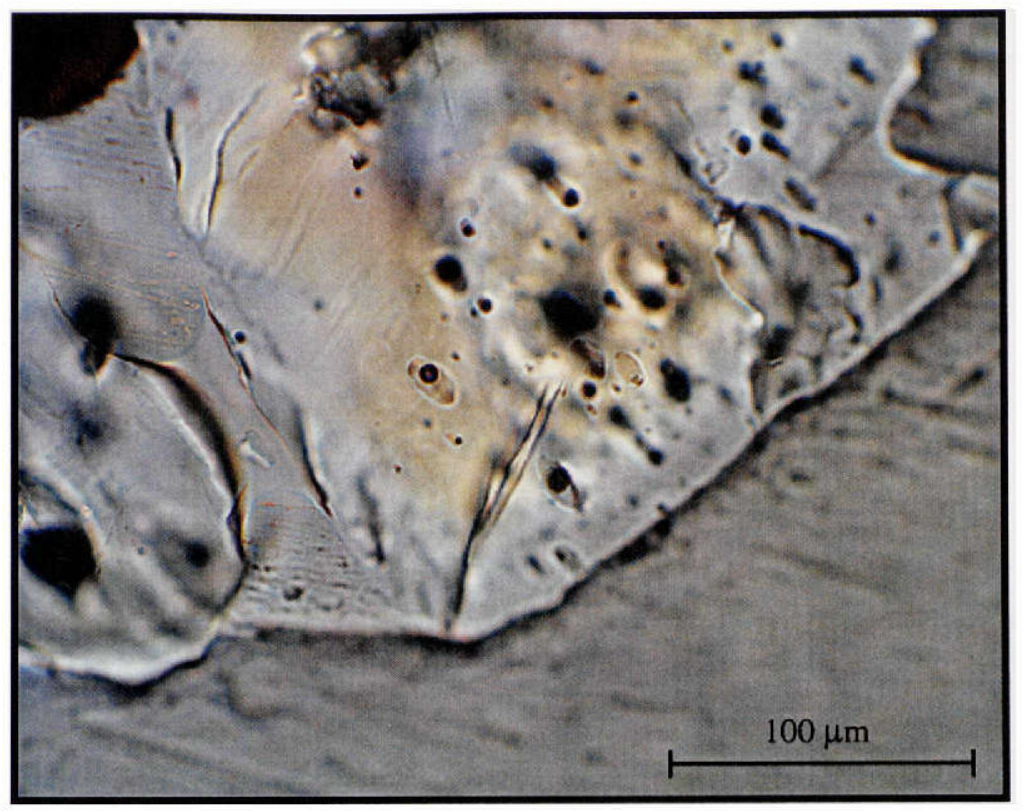

Figure 5-7: Melt inclusions after re-homogenization at $1100^{\circ} \mathrm{C}$. Melt inclusions are rectangular to oval and show exsolved vapor bubbles. Picture is in plane polarized light, magnification $400 \mathrm{x}$.

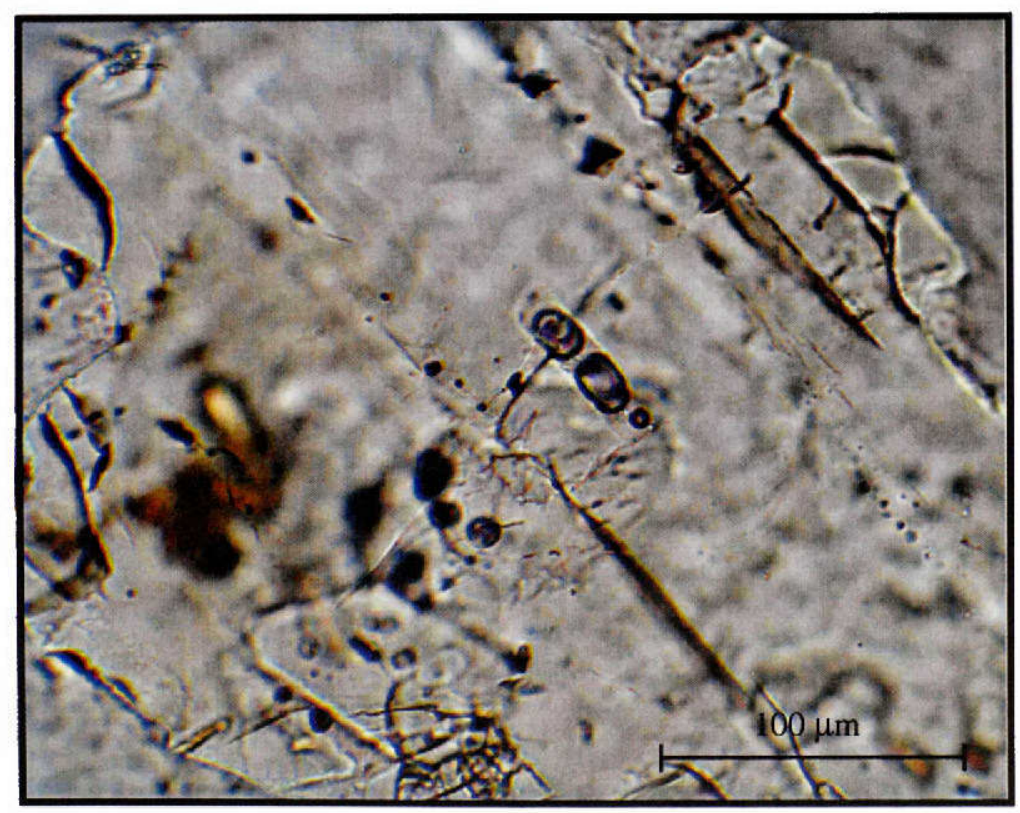

Figure 5-8: Melt inclusion after re-homogenization experiment showing multiple vapor bubbles. Picture is in plane polarized light, magnification $400 x$. 


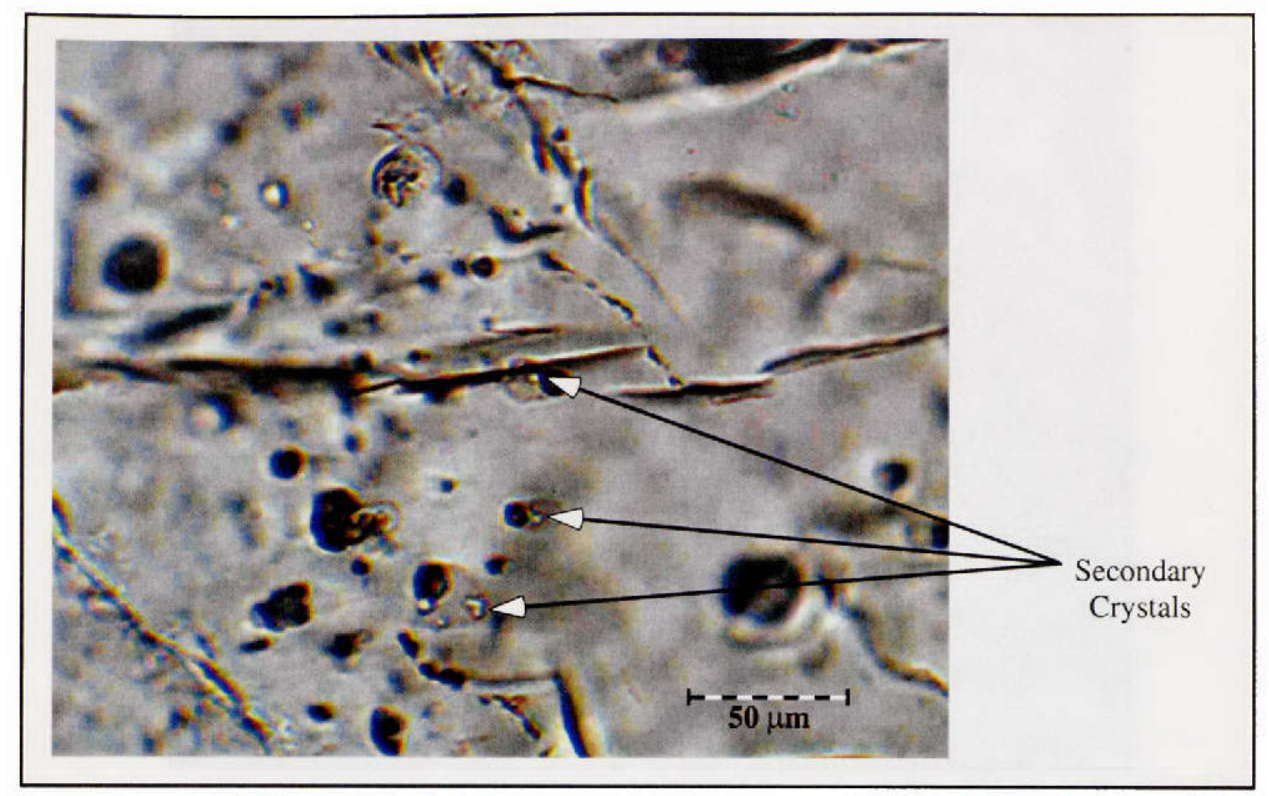

Figure 5-9: Melt inclusions after re-homogenization at $1090^{\circ} \mathrm{C}$. Multiple secondary crystals are readily seen within the inclusions. Picture is in plane polarized light, magnification enhanced from $400 x$.

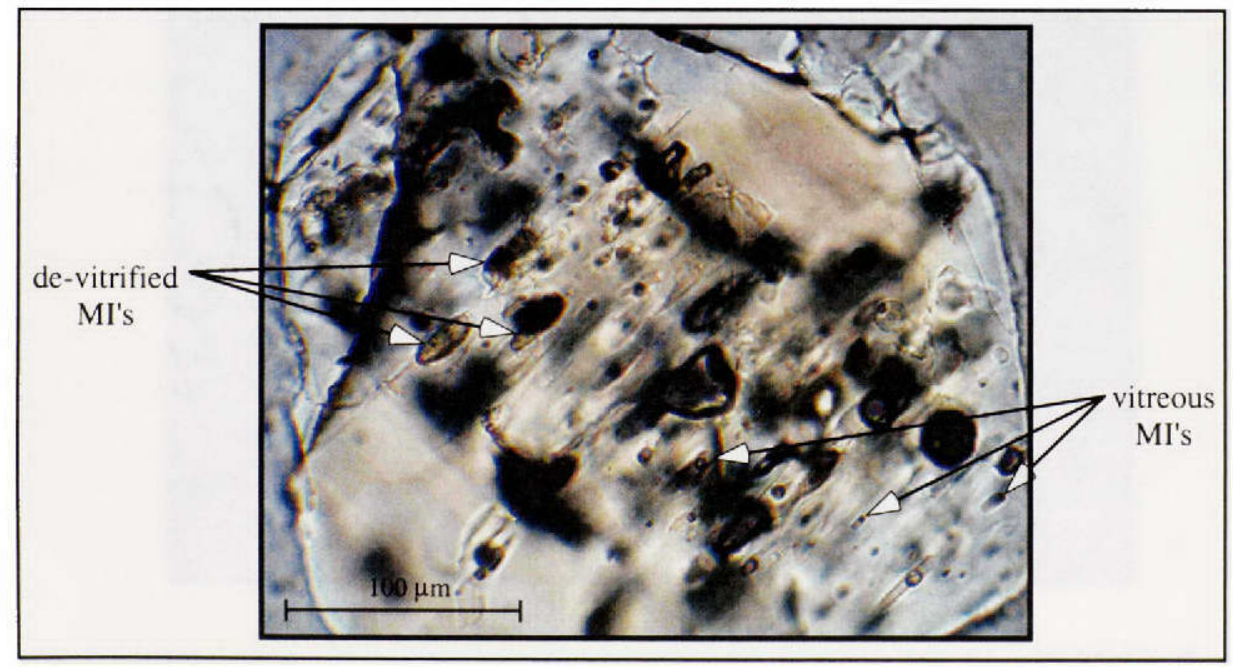

Figure 5-10: Plagioclase crystal after re-homogenization showing both vitreous and de-vitrified melt inclusions. Picture is in plane polarized light, magnification $400 x$. 

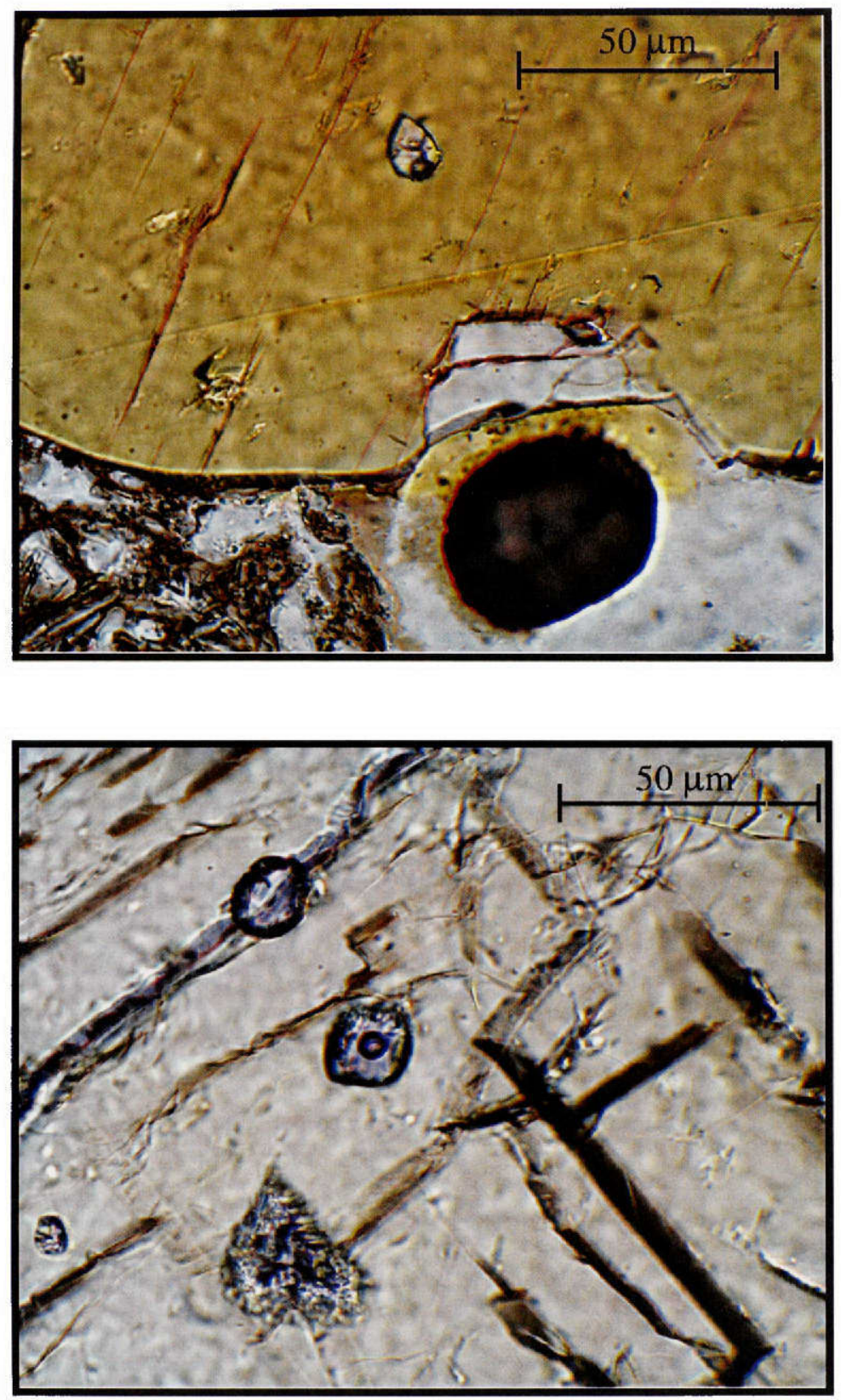

Figure 5-11: Melt inclusions in hornblende and pyroxene from sample 1004-421. Shapes of MI's are rounded (right) to diamond like (left) and MI's contain a single vapor bubble. Magnification of both pictures is $400 \mathrm{x}$. 


\section{CHAPTER 6: RESULTS}

\subsection{Experimental Run Results}

Melt inclusions were reheated in the one atmosphere furnace homogenize in steps. Under atmospheric conditions, all melt inclusions became vitreous at $1200^{\circ} \mathrm{C}$. At $1150^{\circ} \mathrm{C}$ and $1140^{\circ} \mathrm{C}$ more than $90 \%$ of MI's are homogeneous. At $1125^{\circ} \mathrm{C}, 75 \%$ of the melt inclusions in plagioclase cores and $100 \%$ of MI's in plagioclase rims are homogeneous (Table 6-1). Controlled fugacity experiments showed similar results. Table 6-2 summarizes these results and shows the amount of post-entrapment/postexperimental crystallization. Again, high temperature runs successfully rehomogenized all melt inclusions and no secondary crystals can be observed. Melt inclusions in runs conducted $\leq 1120^{\circ} \mathrm{C}$ show secondary crystals. As seen in the previous chapter (Fig. 513), these crystals have a square shape and are light green in color. An analysis performed on one of the secondary crystals shows it to be clinopyroxene (Table 6-3). Runs conducted at $1110^{\circ} \mathrm{C}$ have between 1 to 3 secondary crystals per MI, while runs conducted at $1100^{\circ} \mathrm{C}$ and below have multiple secondary crystals.

\subsection{Major Elements}

Melt inclusions from Fuego de Colima are all highly slicic $\left(\mathrm{SiO}_{2}: 60-75\right.$ wt. \%). Unhomogenized MI's show the widest variation in all elements (Table 6-4). $\mathrm{SiO}_{2}$ is 63$75 \% . \mathrm{Al}_{2} \mathrm{O}_{3}$ is most variable in these samples. It ranges from $2.88-21.8 \%$ by weight but most samples contain approximately $15-18$ wt. $\% \mathrm{Al}_{2} \mathrm{O}_{3} . \mathrm{MgO}, \mathrm{FeO}$ and $\mathrm{TiO}_{2}$ range from trace levels, 0.25 wt. $\%$ and 0.017 wt. $\%$ to 5.57 wt. $\%, 5.39$ wt. $\%$ and 1.08 wt. $\%$, 


\begin{tabular}{|c|c|c|c|}
\hline Run \# & Temp (oC) & Run Duration & Results \\
\hline DI 194.1 & 1000 & 4 hrs. $16 \mathrm{~min}$ & $\begin{array}{l}\text { Homogenization of }<10 \% \text { rim MI's } \\
\text { Core MI's de-vitirified }\end{array}$ \\
\hline DI 194.2 & 1100 & 4 hrs. 8 min. & $\begin{array}{l}100 \% \text { homogenization of rim MI's } \\
<50 \% \text { homogenization core MI's }\end{array}$ \\
\hline DI 194.5 & 1125 & $4 \mathrm{hrs} .1 \mathrm{~min}$ & $\begin{array}{l}100 \% \text { homogenization of rim MI's } \\
75 \% \text { homogenization core MI's } \\
\text { (dependant on crystal)* }^{*}\end{array}$ \\
\hline DI 194.3 & 1200 & 4 hrs. 12 min. & $100 \%$ of all MI's in cores and rims \\
\hline DI 194.4 & 1150 & 4 hrs. 2 min. & $100 \%$ of all MI's in cores and rims \\
\hline
\end{tabular}

Table 6-1 - Run results for DI-194 samples (1869 lava flow). * Certain crystals from this run were homogenized completely while others showed homogenization of rim MI's with de-vitrified core MI's similar to those seen in prior runs

\begin{tabular}{|c|c|c|c|c|}
\hline Run \# & Temp (oC) & $-\log f o 2$ & Duration (Min) & Results \\
\hline DI-194-CF 1 & 1140 & -8.41 & 40 & $\begin{array}{l}\text { Complete homogenization of Ml's in } \\
\text { all cores and rims }\end{array}$ \\
\hline DI-194-CF 1b & 1150 & -8.35 & 31 & $\begin{array}{l}\text { Complete homogenization of MI's in } \\
\text { all cores and rims }\end{array}$ \\
\hline DI-194-CF 1c & $\mathrm{I} 150$ & -8.35 & 64 & $\begin{array}{l}\text { Complete homogenization of MI's in } \\
\text { all cores and rims }\end{array}$ \\
\hline DI-194-CF 2 & 1130 & -8.75 & 40 & $\begin{array}{l}\text { Homogenization in Cores and Rims } \\
\text { Less than } 5 \% \text { of MI's contain a single } \\
\text { green secondary crystal }\end{array}$ \\
\hline D1-194-CF 3 & 1120 & -8.81 & 40 & $\begin{array}{l}\text { Homogenization of rim Ml's with } \\
>50 \% \text { homogenization of core MI's. } \\
2-3 \text { green secondary crystals are } \\
\text { common in larger MI's }\end{array}$ \\
\hline DI-194-CF 4 & 1110 & -9.89 & 40 & $\begin{array}{l}\text { Homogenization of } 90 \% \text { of rim MI's } \\
\text { and }<50 \% \text { of Core MI's. Large MI's } \\
\text { contain multiple secondary crystals } \\
\text { usually clustered near MI wall. }\end{array}$ \\
\hline DI-194-CF 5 & 1000 & -9.34 & 35 & $\begin{array}{l}\text { Homogenization of } 50-75 \% \text { of rim } \\
\text { MI's. Core MI's are de-vitrified }\end{array}$ \\
\hline DI-194-CF 6 & 1090 & -9.11 & 40 & $\begin{array}{l}\text { Homogenization of }<25 \% \text { of Rim } \\
\text { MI's. Core MI's are de-vitrified }\end{array}$ \\
\hline DI-194-CF 6b & 1090 & -9.12 & 62 & $\begin{array}{l}\text { Homogenization of }<25 \% \text { of Rim } \\
\text { MI's. Core MI's are de-vitrified }\end{array}$ \\
\hline DI-194-CF 7 & 1080 & -9.25 & 45 & $\begin{array}{l}\text { No homogenization of MI's was } \\
\text { visible in plagioclase Ml's }\end{array}$ \\
\hline DI-194-CF 7b & 1080 & -9.24 & 62 & $\begin{array}{l}\text { No homogenization of Ml's was } \\
\text { visible in plagioclase Ml's }\end{array}$ \\
\hline
\end{tabular}

Table 6-2 - Run results for controlled fugacity experiments. Runs conducted above 1130 were fully effective in homogenizing MI's and dissolving or hindering growth of secondary crystals 


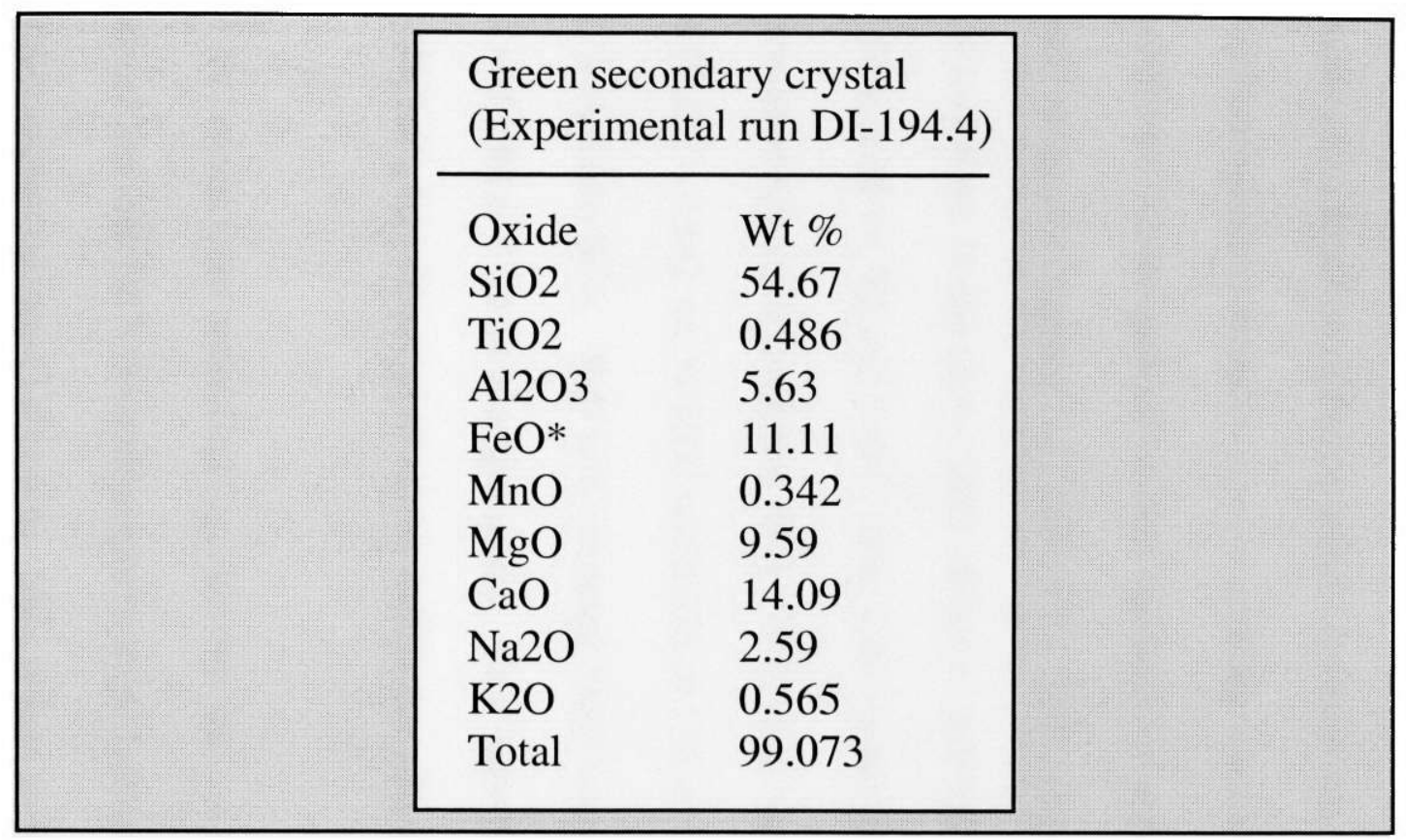

Table 6-3: EPMA analysis of secondary crystals in plagioclase MI's. Analysis on the green crystal is from DI-194 CF4. 
respectively, and values are lowest in MI's hosted by the mafic minerals (e.g., cpx, opx and hornblende). $\mathrm{K}_{2} \mathrm{O}, \mathrm{CaO}$ and $\mathrm{Na}_{2} \mathrm{O}$ (corrected values) also show wide variations in composition range from and 0.21 to $4.28 \mathrm{wt} \% \%, 1.17-5.56 \mathrm{wt} \% \%$ and 2.24 to $5.63 \% \mathrm{wt}$. $\%$ respectively and there does not seem to be any systematic difference in concentration of these elements as a function of host mineral. Furthermore, none of the major elements analyzed in unhomogenized samples seem to correlate with $\mathrm{SiO}_{2}$ (Fig. 6-1).

Experimental rehomogenization runs conducted at atmospheric conditions show a much narrower range of compositions (Table 6-5). $\mathrm{SiO}_{2}$ ranges from 64.5 to $73.1 \mathrm{wt}$ \% $\%$. $\mathrm{Al}_{2} \mathrm{O}_{3}$ is 15.4 to 18.6 wt. $\%$ and shows little variation with $\mathrm{SiO}_{2} . \mathrm{MgO}(0.43$ to 1.95 wt. \%), $\mathrm{CaO}(2.14$ to 4.40 wt. \%) and $\mathrm{FeO}(1.03$ to 4.26 wt. \%) are most variable. These elements show an inverse relationship to $\mathrm{SiO}_{2} . \mathrm{TiO}_{2}$, and $\mathrm{MnO}$ show small variations in composition $(0.358-0.642$ wt. \% $\mathrm{TiO} 2$ and $0.025-0.123$ wt. \% $\mathrm{MnO})$ and tend to be higher in MI's with low $\mathrm{SiO}_{2} . \mathrm{K}_{2} \mathrm{O}$ and corrected $\mathrm{Na}_{2} \mathrm{O}$ concentrations range from 0.503 - 1.51 wt. \% and 1.88 to 3.04 wt \% respectively. They both show some increase with increasing $\mathrm{SiO}_{2}$ but a large amount of scatter makes this relationship somewhat unclear (Fig. 6-2)

Melt Inclusions from controlled fugacity runs show a wider variation in major element composition then MI's from atmospheric experiments, but the variation was not as wide as unhomogenized runs (Table 6-6). $\mathrm{SiO}_{2}$ ranges from 60.7 to 74.6 wt. \%. $\mathrm{FeO}$ (1.88-5.68 wt. \%), $\mathrm{CaO}$ (1.26-6.67 wt. \%), $\mathrm{Al}_{2} \mathrm{O}_{3}$ (10.17-20.35 wt \%), $\mathrm{Na}_{2} \mathrm{O}$ (3.38 to 6.95 wt. \%, after corrections) and for the most part $\mathrm{MgO}(0.121-2.17 \mathrm{wt} \%)$, all tend to have high values at low $\mathrm{SiO}_{2}$ and decrease with increasing $\mathrm{SiO}_{2}$ (Fig 6-3). $\mathrm{K}_{2} \mathrm{O}$ show the opposite trend. It is highest (2.88 wt. \%) with highest $\mathrm{SiO}_{2}$ and lowest (1.36 wt \%) at low 
Table 6-4 EPMA analysis of melt inclusions in natural samples from Fuego de Colima (1869-1913)

\begin{tabular}{|c|c|c|c|c|c|c|c|c|c|c|c|c|c|}
\hline \multicolumn{14}{|c|}{$\begin{array}{l}\text { Melt Inclusion Analysis - } \\
1004-421 \text { (1913) }\end{array}$} \\
\hline & $\mathrm{SiO} 2$ & $\mathrm{TiO} 2$ & $\mathrm{~A} 1203$ & $\mathrm{FeO}^{\mathrm{T}}$ & $\mathrm{MnO}$ & $\mathrm{MgO}$ & $\mathrm{CaO}$ & $\mathrm{Na} 20$ & $\mathrm{Na} 20 \dagger$ & $\mathrm{K} 20$ & Total & Total $\dagger$ & $\mathrm{n}^{*}$ \\
\hline 1004-421PL-MI1 & 75.270 & 0.357 & 8.377 & 5.390 & 0.092 & 1.617 & 1.891 & 4.430 & 5.780 & 0.211 & 97.635 & 98.985 & 3 \\
\hline 1004-421 PL-MI2 & 63.470 & 1.080 & 13.390 & 8.530 & 0.160 & 2.590 & 2.190 & 2.720 & 4.070 & 1.630 & 95.760 & 97.110 & 1 \\
\hline 1004-421PX-MI1 & 70.050 & 0.026 & 15.628 & 0.236 & 0.021 & 0.020 & 1.166 & 0.890 & 2.240 & 1.184 & 89.221 & 90.571 & 5 \\
\hline 1004-421PX-MI2 & 70.635 & 0.017 & 15.080 & 0.260 & 0.014 & 0.000 & 1.198 & 1.073 & 2.423 & 1.370 & 89.646 & 90.996 & 2 \\
\hline 1004-421HBL-MI & 68.300 & 0.025 & 16.300 & 0.356 & 0.032 & - & 1.600 & 1.430 & 2.780 & 1.570 & 89.614 & 90.964 & 1 \\
\hline \multicolumn{14}{|c|}{$\begin{array}{l}\text { Melt Inclusion Analysis - } \\
\text { M82-11 (1880) }\end{array}$} \\
\hline M82-1 1 PL-MI-1 & 70.465 & 0.447 & 12.020 & 5.070 & 0.138 & 1.519 & 1.690 & 5.160 & 6.510 & 4.275 & 100.783 & 102.133 & 2 \\
\hline M82-11PX-MI-1 & 70.367 & 0.387 & 17.627 & 1.693 & 0.068 & 0.652 & 2.100 & 1.469 & 2.819 & 1.797 & 96.160 & 97.510 & 3 \\
\hline M82-11PX-MI-2 & 69.680 & 0.370 & 17.910 & 1.370 & 0.052 & 0.188 & 2.200 & 2.190 & 3.540 & 2.870 & 96.829 & 98.179 & 2 \\
\hline \multicolumn{14}{|c|}{$\begin{array}{l}\text { Melt Inclusion Analysis - } \\
\text { 91-68 (1880?) }\end{array}$} \\
\hline 91-68PX-MI-1 & 69.388 & 0.589 & 18.555 & 1.496 & 0.050 & 0.198 & 2.438 & 1.568 & 2.918 & 2.065 & 96.345 & 97.695 & 4 \\
\hline 91-68HBL-MI-1 & 67.610 & 0.296 & 21.750 & 1.088 & 0.041 & 0.070 & 1.940 & 1.660 & 3.010 & 1.850 & 96.305 & 97.655 & 1 \\
\hline \multicolumn{14}{|c|}{$\begin{array}{l}\text { Melt Inclusion Analysis - } \\
\text { 1004-414 (1869) }\end{array}$} \\
\hline 1004-414PL-MI2 & 61.770 & 0.693 & 15.687 & 4.866 & 0.104 & 2.071 & 4.650 & 8.147 & 9.497 & 1.897 & 99.885 & 101.235 & 3 \\
\hline 1004-414PX-MI1 & 69.190 & 0.270 & 17.780 & 0.834 & 0.033 & 0.340 & 1.880 & 1.800 & 3.150 & 1.680 & 93.808 & 95.158 & 1 \\
\hline 1004-414HBL-MI & 69.450 & 0.195 & 2.880 & 0.860 & 0.007 & 5.570 & 5.555 & 3.560 & 4.910 & 0.473 & 88.549 & 89.899 & 2 \\
\hline
\end{tabular}

$\uparrow$ These columns represent corrected values after $1.35 \mathrm{wt} \% \mathrm{Na} 2 \mathrm{O}$ addition.

* $\mathrm{n}$ equals the number of analyses taken on individual melt inclusions (see appendix $\mathrm{D}$ for standard deviation of averages). 
Table 6-5: EPMA analysis of melt inclusions from controlled fugacity re-homogenization experiments on sample DI-194 (1869).

\begin{tabular}{|c|c|c|c|c|c|c|c|c|c|c|c|c|c|}
\hline \multicolumn{14}{|c|}{$\begin{array}{l}\text { Melt Inclusion analysis for } \\
\text { controlled } \mathrm{fo}_{2} \text { run at } 1150^{\circ} \mathrm{C}\end{array}$} \\
\hline & $\mathrm{SiO} 2$ & $\mathrm{TiO} 2$ & $\mathrm{Al} 2 \mathrm{O} 3$ & $\mathrm{FeO}^{\mathrm{T}}$ & $\mathrm{MnO}$ & $\mathrm{MgO}$ & $\mathrm{CaO}$ & $\mathrm{Na} 2 \mathrm{O}$ & $\mathrm{Na} 2 \mathrm{O}_{\dagger}$ & $\mathrm{K} 2 \mathrm{O}$ & Total & Total $\dagger$ & $\mathrm{n}^{*}$ \\
\hline DI194CFIb.2a & 60.220 & 0.426 & 16.110 & 4.250 & 0.088 & 1.427 & 4.650 & 4.130 & 5.480 & 1.700 & 93.001 & 94.351 & 1 \\
\hline DI194CFIb.2b & 65.700 & 0.441 & 16.310 & 3.970 & 0.064 & 1.213 & 3.460 & 3.610 & 4.960 & 1.900 & 96.668 & 98.018 & 1 \\
\hline DI194CFIb.2c & 65.300 & 0.390 & 16.510 & 3.940 & 0.046 & 1.218 & 3.560 & 3.720 & 5.070 & 1.835 & 96.518 & 97.868 & 2 \\
\hline DI194CFlb.2d & 62.120 & 0.607 & 16.780 & 5.055 & 0.096 & 1.551 & 5.180 & 1.459 & 2.845 & 1.238 & 94.086 & 95.436 & 2 \\
\hline DI194CF1b.2e & 61.960 & 0.475 & 16.910 & 4.060 & 0.076 & 1.299 & 3.910 & 5.280 & 6.630 & 1.480 & 95.451 & 96.801 & 1 \\
\hline \multicolumn{14}{|c|}{$\begin{array}{l}\text { Melt Inclusion analysis for } \\
\text { controlled } \mathrm{fo}_{2} \text { run at } 1140^{\circ} \mathrm{C}\end{array}$} \\
\hline DI194CF2.1a & 68.120 & 0.512 & 15.960 & 2.290 & 0.029 & 0.277 & 2.250 & 4.570 & 5.920 & 2.620 & 96.629 & 97.979 & 1 \\
\hline DI194CF2.1c & 72.680 & 0.441 & 12.060 & 1.880 & 0.045 & 0.121 & 1.264 & 3.720 & 4.620 & 2.330 & 94.541 & 95.891 & 1 \\
\hline \multicolumn{14}{|c|}{$\begin{array}{l}\text { Melt Inclusion analysis for } \\
\text { controlled } \mathrm{fo}_{2} \text { run at } 1130^{\circ} \mathrm{C}\end{array}$} \\
\hline DI194CF3.1a & 65.088 & 0.405 & 14.398 & 5.405 & 0.142 & 3.151 & 3.410 & 3.183 & 4.533 & 1.950 & 97.131 & 98.481 & 4 \\
\hline DI194CF3.2b & 68.880 & 0.739 & 13.623 & 4.030 & 0.072 & 1.233 & 1.620 & 2.430 & 3.780 & 3.020 & 95.647 & 96.997 & 3 \\
\hline DI194CF3.2c & 72.523 & 0.571 & 12.053 & 2.377 & 0.043 & 0.759 & 1.280 & 3.583 & 4.933 & 2.867 & 96.057 & 97.407 & 3 \\
\hline \multicolumn{14}{|c|}{$\begin{array}{l}\text { Melt Inclusion analysis for } \\
\text { controlled } \mathrm{fo}_{2} \text { run at } 1120^{\circ} \mathrm{C}\end{array}$} \\
\hline DI194CF4.1b & 62.370 & 0.677 & 14.860 & 5.720 & 0.112 & 1.980 & 4.710 & 5.030 & 6.830 & 1.830 & 97.289 & 98.639 & 1 \\
\hline DI194CF4.1c & 64.365 & 0.447 & 14.990 & 4.460 & 0.099 & 1.790 & 3.720 & 4.700 & 6.050 & 1.765 & 96.335 & 97.685 & 2 \\
\hline DI194CF4.1d & 60.775 & 0.618 & 15.795 & 5.425 & 0.097 & 2.165 & 4.960 & 5.595 & 6.945 & 1.425 & 96.855 & 98.205 & 2 \\
\hline
\end{tabular}

$\dagger$ These columns represent values after addition of $1.35 \mathrm{wt} \% \mathrm{Na} 2 \mathrm{O}$

${ }^{*} \mathrm{n}$ equals the number of analyses taken on individual melt inclusions (see Appendix D for individual analyses). 
Table 6-6: EPMA analysis of 1 atmosphere ${ }^{\ddagger}$ re-homogenization experiments.

\begin{tabular}{|c|c|c|c|c|c|c|c|c|c|c|c|c|c|}
\hline Spot/line & $\mathrm{SiO} 2$ & $\mathrm{TiO} 2$ & $\mathrm{~A} 12 \mathrm{O} 3$ & $\mathrm{FeO}^{\mathrm{T}}$ & $\mathrm{MnO}$ & $\mathrm{MgO}$ & $\mathrm{CaO}$ & $\mathrm{Na} 2 \mathrm{O}$ & $\mathrm{Na} 2 \mathrm{O} \dagger$ & $\mathrm{K} 2 \mathrm{O}$ & Total & Total $\dagger$ & $\mathrm{n}^{*}$ \\
\hline 5 & 73.148 & 0.455 & 18.684 & 2.118 & 0.049 & 0.613 & 2.139 & 0.657 & 2.007 & 1.170 & 99.033 & 100.383 & 1 \\
\hline 9 & 70.223 & 0.508 & 16.066 & 2.610 & 0.070 & 0.774 & 3.342 & 0.616 & 1.966 & 1.531 & 95.740 & 97.090 & 1 \\
\hline 10 & 75.204 & 0.380 & 15.406 & 1.669 & 0.084 & 0.429 & 2.547 & 0.503 & 1.853 & 1.486 & 97.708 & 99.058 & 1 \\
\hline Ave for $184 / 219$ & 67.172 & 0.642 & 17.166 & 4.262 & 0.123 & 1.947 & 4.400 & 0.605 & 1.955 & 1.293 & 97.610 & 98.960 & 2 \\
\hline Ave $185 / 216$ & 64.465 & 0.620 & 17.053 & 4.056 & 0.094 & 1.946 & 4.371 & 1.429 & 2.779 & 1.232 & 95.266 & 96.616 & 2 \\
\hline Ave 191/222/224/229 & 72.725 & 0.395 & 16.254 & 2.934 & 0.097 & 0.743 & 3.040 & 1.273 & 2.623 & 1.372 & 98.833 & 100.183 & 4 \\
\hline Ave $202 / 239 / 240 / 241$ & 71.434 & 0.525 & 18.273 & 2.761 & 0.063 & 0.773 & 3.130 & 1.446 & 2.796 & 1.499 & 99.904 & 101.254 & 4 \\
\hline Ave $226 / 227 / 242$ & 68.160 & 0.462 & 16.863 & 3.059 & 0.066 & 0.886 & 3.915 & 1.922 & 3.272 & 1.510 & 96.843 & 98.193 & 3 \\
\hline $280 \mathrm{G}$ & 68.878 & 0.491 & 17.992 & 2.139 & 0.064 & 0.854 & 3.474 & 1.808 & 3.158 & 1.094 & 96.794 & 98.144 & 1 \\
\hline $281 G$ & 69.208 & 0.463 & 18.027 & 2.377 & 0.056 & 0.794 & 3.333 & 1.379 & 2.729 & 1.174 & 96.811 & 98.161 & 1 \\
\hline $282 \mathrm{G}$ & 67.811 & 0.498 & 17.215 & 2.137 & 0.117 & 0.651 & 3.786 & 1.694 & 3.044 & 1.089 & 94.998 & 96.348 & 1 \\
\hline $283 \mathrm{G}$ & 70.006 & 0.346 & 16.845 & 2.427 & 0.083 & 0.780 & 3.483 & 1.427 & 2.777 & 1.169 & 96.566 & 97.916 & 1 \\
\hline $284 \mathrm{G}$ & 72.976 & 0.383 & 17.772 & 1.026 & 0.064 & 0.892 & 2.753 & 1.497 & 2.847 & 1.114 & 98.477 & 99.827 & 1 \\
\hline $285 \mathrm{G}$ & 70.642 & 0.500 & 17.785 & 2.004 & 0.039 & 0.820 & 3.085 & 1.535 & 2.885 & 1.098 & 97.508 & 98.858 & 1 \\
\hline $286 \mathrm{G}$ & 69.893 & 0.461 & 17.253 & 2.155 & 0.075 & 0.526 & 2.853 & 1.276 & 2.626 & 1.201 & 95.693 & 97.043 & 1 \\
\hline $287 \mathrm{G}$ & 68.302 & 0.488 & 17.394 & 2.554 & 0.025 & 0.624 & 3.356 & 1.794 & 3.144 & 1.181 & 95.718 & 99.086 & 1 \\
\hline $288 \mathrm{G}$ & 68.174 & 0.390 & 17.508 & 2.658 & 0.106 & 0.874 & 4.224 & 1.740 & 3.090 & 1.165 & 96.839 & 98.189 & 1 \\
\hline
\end{tabular}

$\dagger$ These columns represent values after addition of $1.35 \mathrm{wt} \% \mathrm{Na} 2 \mathrm{O}$

* $\mathrm{n}$ equals the number of analyses taken on individual melt inclusions (see Appendix D for individual analyses).

$\ddagger$ All analyses from run DI-194-3 (Conditions were $1100^{\circ} \mathrm{C}$ and atmospheric $f_{\mathrm{O}_{2}}$ ). 


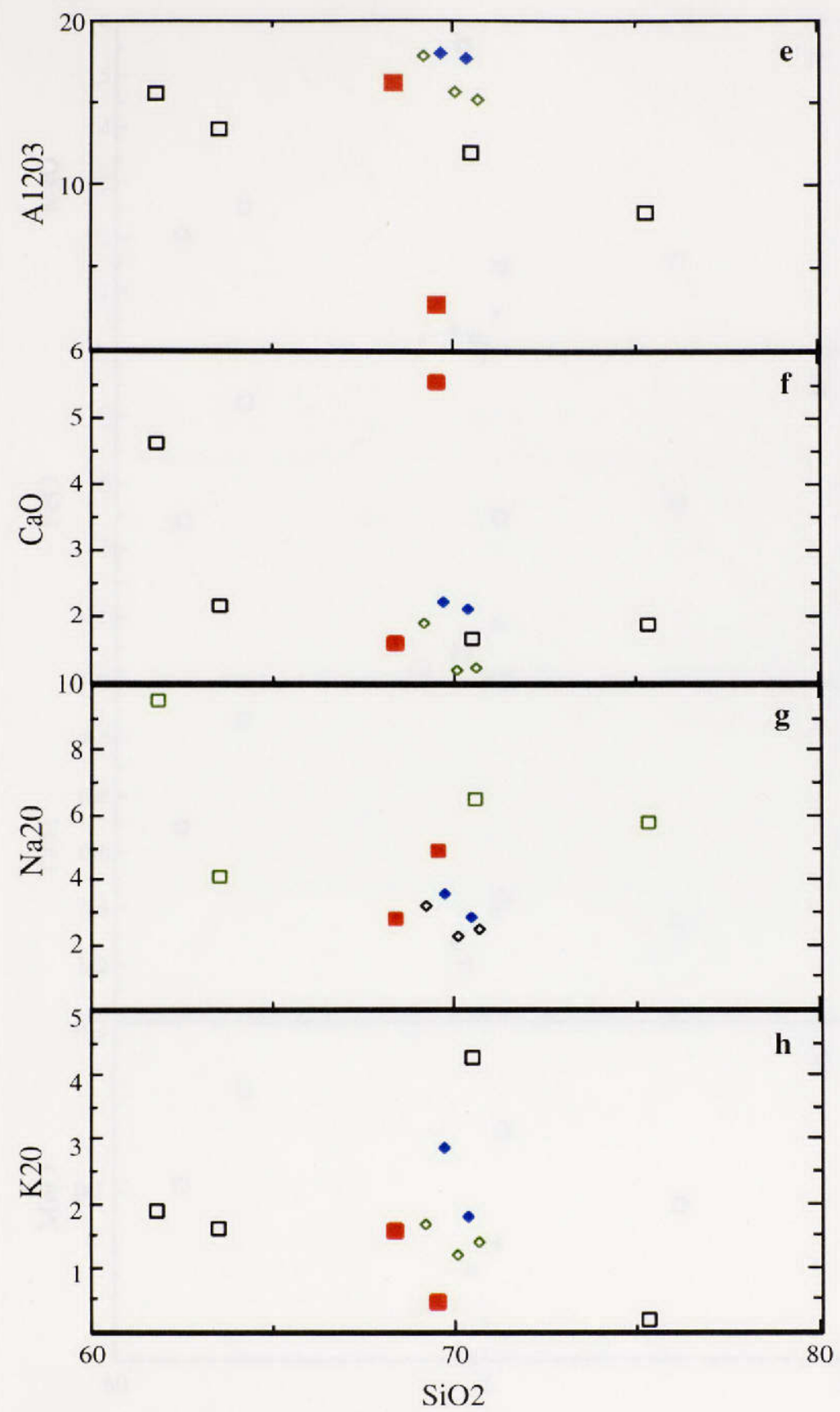

Figure 6-1: Plot of major elements versus $\mathrm{SiO}_{2}$ for un-homogenized melt inclusions. Symbols represent melt inclusions hosted by plagioclase $\square, c p x \circ$, opx - and hornblende $\mathrm{Na}_{2} \mathrm{O}$ represents corrected values (see table6-4). 


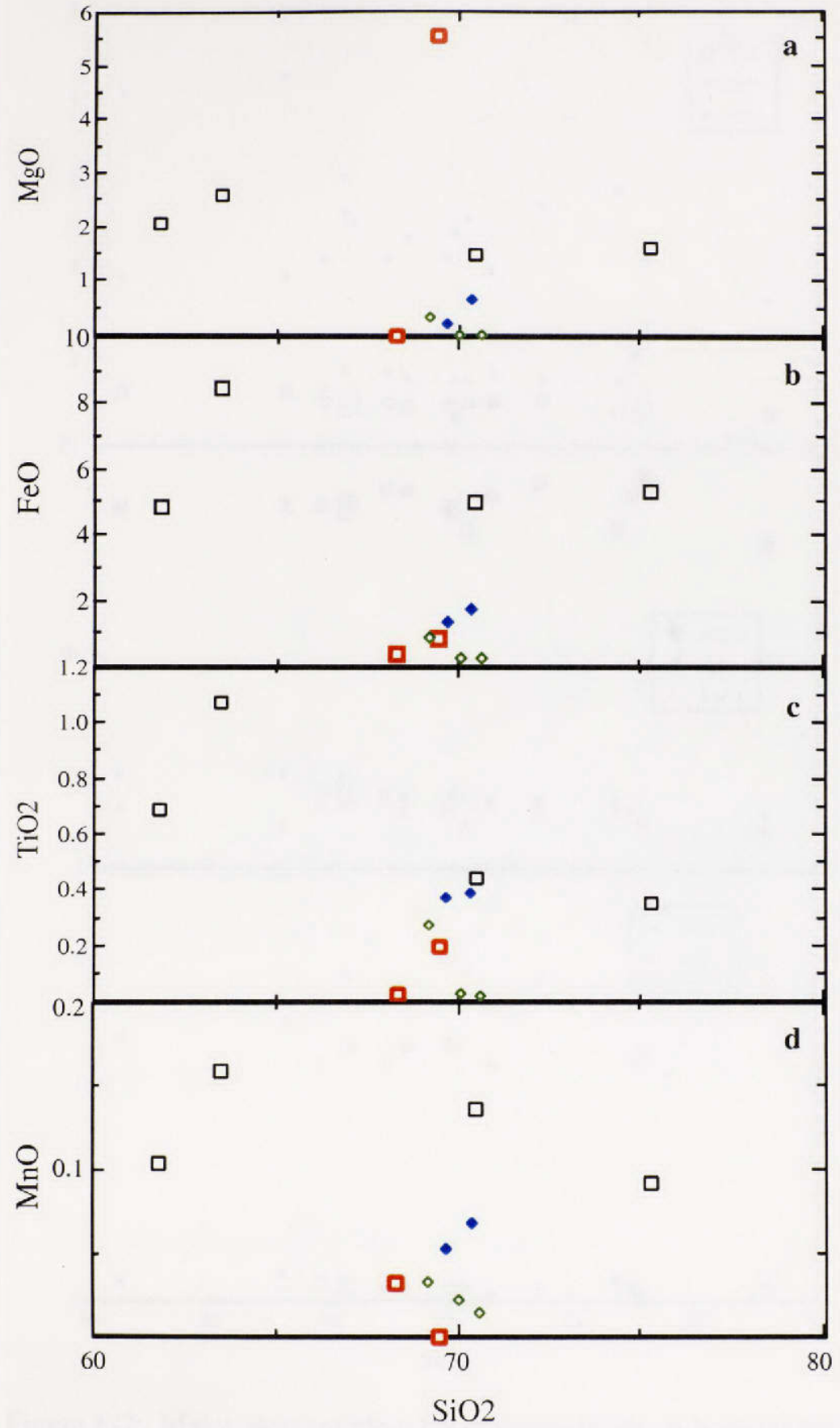

Figure 6-1 (cont.): Plot of major elements versus $\mathrm{SiO} 2$ for un-homogenized melt inclusions. Symbols represent melt inclusions hosted by plagioclase $\square$, $\operatorname{cpx} \diamond$, opx $\bullet$ and hornblende $\square$. 


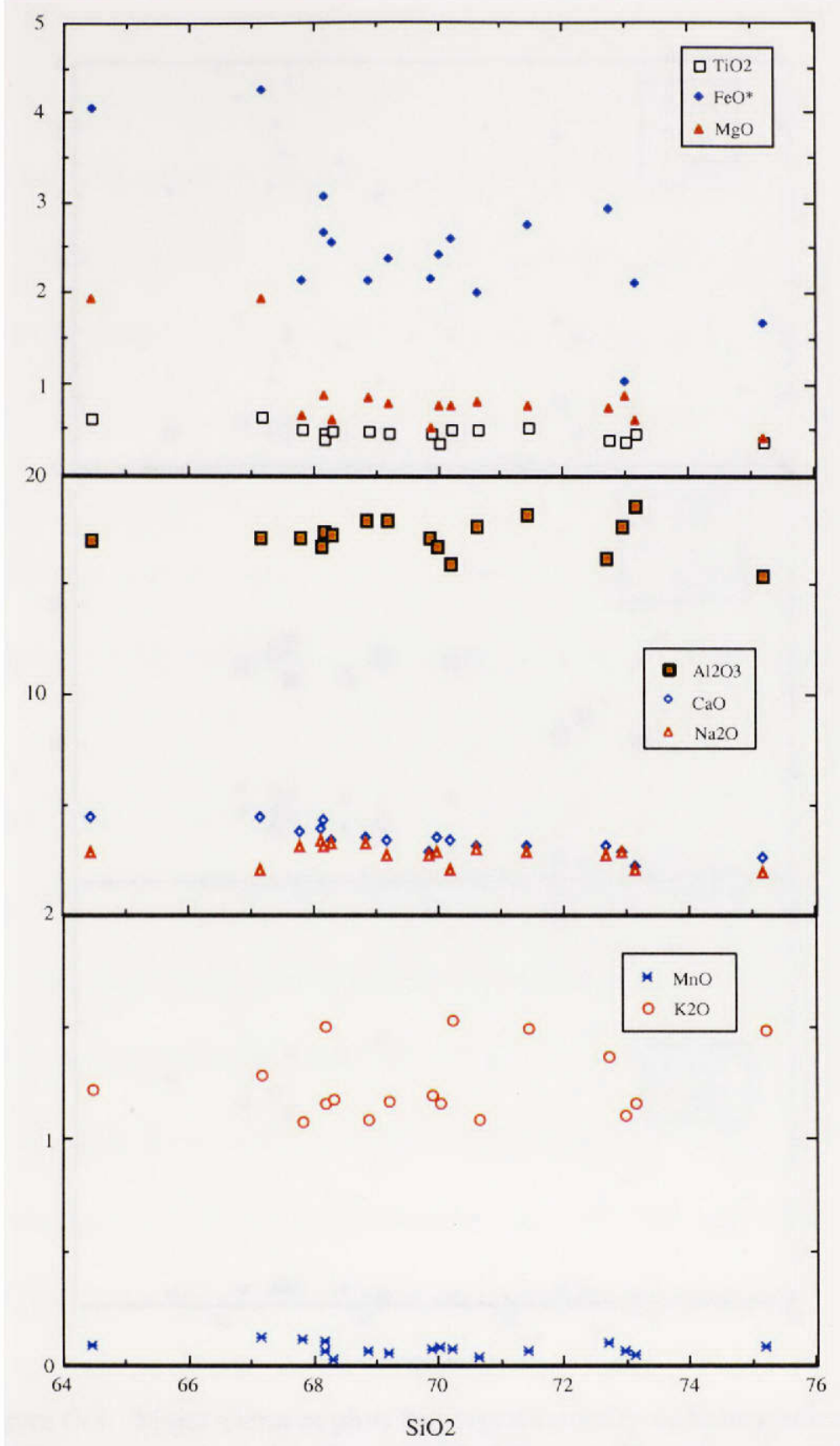

Figure 6-2: Major element plots for experimentally re-homogenized MI's. Heating runs conducted under atmospheric conditions. $\mathrm{Na}_{2} \mathrm{O}$ values reflect $1.35 \%$ sodium addition (see Table 6-5). 


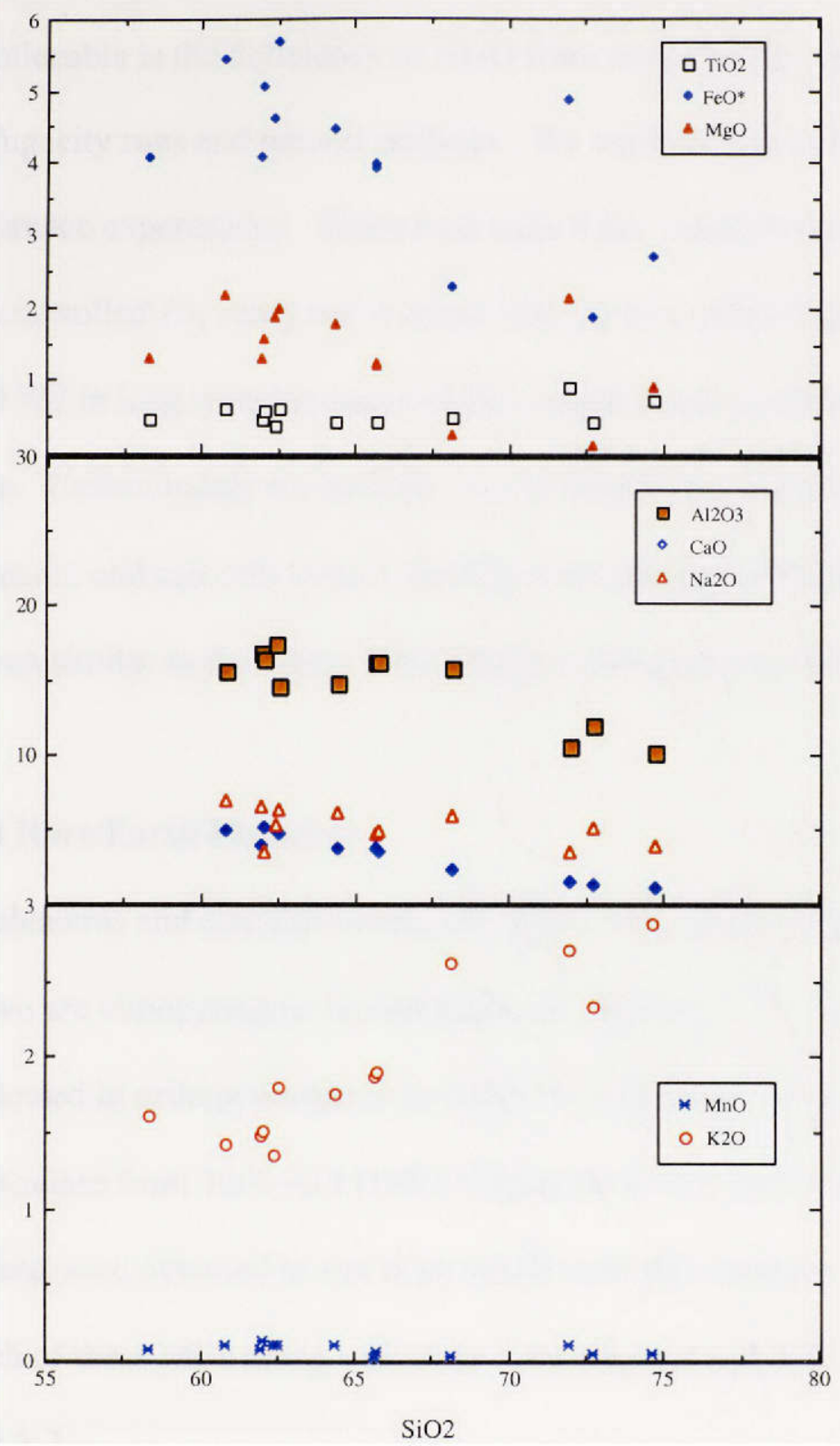

Figure 6-3: Major element plots for experimentally re-homogenized MI's. Heating runs conducted under controlled $\mathrm{fO}_{2}$ conditions listed in table 6-1 and Appendix A. $\mathrm{Na}_{2} \mathrm{O}$ values reflect $1.35 \%$ sodium addition (see Table 6-6). 
values of $\mathrm{SiO}_{2}$. Again, $\mathrm{TiO}_{2}$ and $\mathrm{MnO}$ tend to show only small variations and are highest in low $\mathrm{SiO}_{2} \mathrm{MI}$ 's.

Still noticeable is the deficiency in $\mathrm{Na}_{2} \mathrm{O}$ from atmospheric runs when compared to controlled fugacity runs and natural analyses. We attribute this to further sodium loss occurring in furnace experiments. These runs were $4 \mathrm{hrs}$. duration (as opposed to $40-60$ min. used for controlled $f \mathrm{O}_{2}$ runs) and it seems that the loss of $\mathrm{H}_{2} \mathrm{O}$ experienced by Nielsen et al, 1995 in long duration runs ( $>2 \mathrm{hrs}$.) applies well to other volatile species such as sodium. Unfortunately we have no way of quantifying $\mathrm{Na}$ loss in the 1 atmosphere furnace and can only expect that the concentration of $\mathrm{Na}_{2} \mathrm{O}$ in these MI's would have been similar to the others if the length of the runs had been shorter.

\subsection{Trace and Rare Earth Elements}

Trace elements and rare earth elements (REE) were analyzed in four melt inclusions. Two are clinopyroxene hosted and come from the 1913 scoria sample (1004421). One is hosted in orthopyroxene from M82-11 (1890 block lava flow) and one hosted by plagioclase from 1004-414 (1869 Volcancito flow). None of these MI's were reheated and data were obtained in situ from whole rock thin sections. Major element analysis of each of these MI's along with their trace element and REE concentrations appear in table 6-7.

Primitive mantle normalized trace elements trends are similar to the 1913 scoria (sample 1004-421 whole rock data analyzed by Luhr \& Carmichael, 1990) (Fig. 6-4). This sample was chosen for comparison because of its primitive composition and because it is the host for two of the 4 MI's analyzed. Luhr and Carmichael (1990) suggest that the 
Table 6-7: Major and trace element analyses of melt inclusions.

\begin{tabular}{|c|c|c|c|c|}
\hline Sample & $1004-414$ & M82-11 & $1004-421$ & $1004-421$ \\
\hline Host & Plagioclase & orthopyroxene & clinopyroxene & clinopyroxene \\
\hline Year of Eruption & 1869 & 1890 & 1913 & 1913 \\
\hline $\mathrm{SiO} 2$ & 60.400 & 69.680 & 70.050 & 70.635 \\
\hline $\mathrm{TiO} 2$ & 0.568 & 0.370 & 0.026 & 0.017 \\
\hline A1203 & 17.550 & 17.910 & 15.628 & 15.080 \\
\hline $\mathrm{FeO}^{\mathrm{T}}$ & 4.720 & 1.370 & 0.236 & 0.260 \\
\hline $\mathrm{MnO}$ & 0.170 & 0.052 & 0.021 & 0.014 \\
\hline $\mathrm{MgO}$ & 1.469 & 0.188 & 0.020 & 0.000 \\
\hline $\mathrm{CaO}$ & 4.100 & 2.200 & 1.166 & 1.198 \\
\hline $\mathrm{Na} 20 \dagger$ & 11.590 & 3.540 & 2.240 & 2.423 \\
\hline $\mathrm{K} 20$ & 2.140 & 2.870 & 1.184 & 1.370 \\
\hline Total & 101.398 & 96.829 & 89.221 & 89.646 \\
\hline $\mathrm{H} 2 \mathrm{O}$ & 0.394 & 0.716 & 3.420 & 2.760 \\
\hline B & 2.815 & 2.815 & 2.019 & 3.039 \\
\hline $\mathrm{Be}$ & 34.463 & 34.463 & 46.486 & 65.327 \\
\hline $\mathrm{Rb}$ & 44.463 & 44.463 & 30.706 & 64.029 \\
\hline $\mathrm{Sr}$ & 156.191 & 156.191 & 165.106 & 232.695 \\
\hline $\mathrm{Y}$ & 15.515 & 15.515 & 3.055 & 22.407 \\
\hline $\mathrm{Zr}$ & 299.987 & 299.987 & 125.338 & 180.240 \\
\hline $\mathrm{Nb}$ & 6.671 & 6.671 & 0.833 & 8.702 \\
\hline $\mathrm{Ba}$ & 744.879 & 504.659 & 702.540 & 950.380 \\
\hline $\mathrm{Ce}$ & 28.458 & 25.528 & 1.661 & 9.478 \\
\hline $\mathrm{Nd}$ & 13.135 & 11.803 & 5.091 & 15.352 \\
\hline $\mathrm{Sm}$ & 4.033 & 1.489 & 4.489 & 19.642 \\
\hline $\mathrm{Eu}$ & 3.186 & 0.508 & 2.191 & 0.000 \\
\hline $\mathrm{Tb}$ & 0.482 & 0.309 & 2.188 & 8.912 \\
\hline Ho & 0.529 & 0.529 & 1.761 & 11.802 \\
\hline $\mathrm{Tm}$ & 0.226 & 0.099 & 1.254 & 8.690 \\
\hline Cs & 0.750 & 0.760 & 1.400 & $\mathrm{n} / \mathrm{a}$ \\
\hline Th & 3.279 & 1.528 & 2.725 & $\mathrm{n} / \mathrm{a}$ \\
\hline $\mathrm{U}$ & 0.783 & 0.710 & 0.549 & $\mathrm{n} / \mathrm{a}$ \\
\hline
\end{tabular}

Major elements analyzed by EPMA, Trace elements and water analyzed by Ion Probe. $\mathrm{n} / \mathrm{a}$ means data not available

$\dagger \mathrm{Na} 2 \mathrm{O}$ represents corrected values after addition of $1.35 \mathrm{wt}$. \%. 


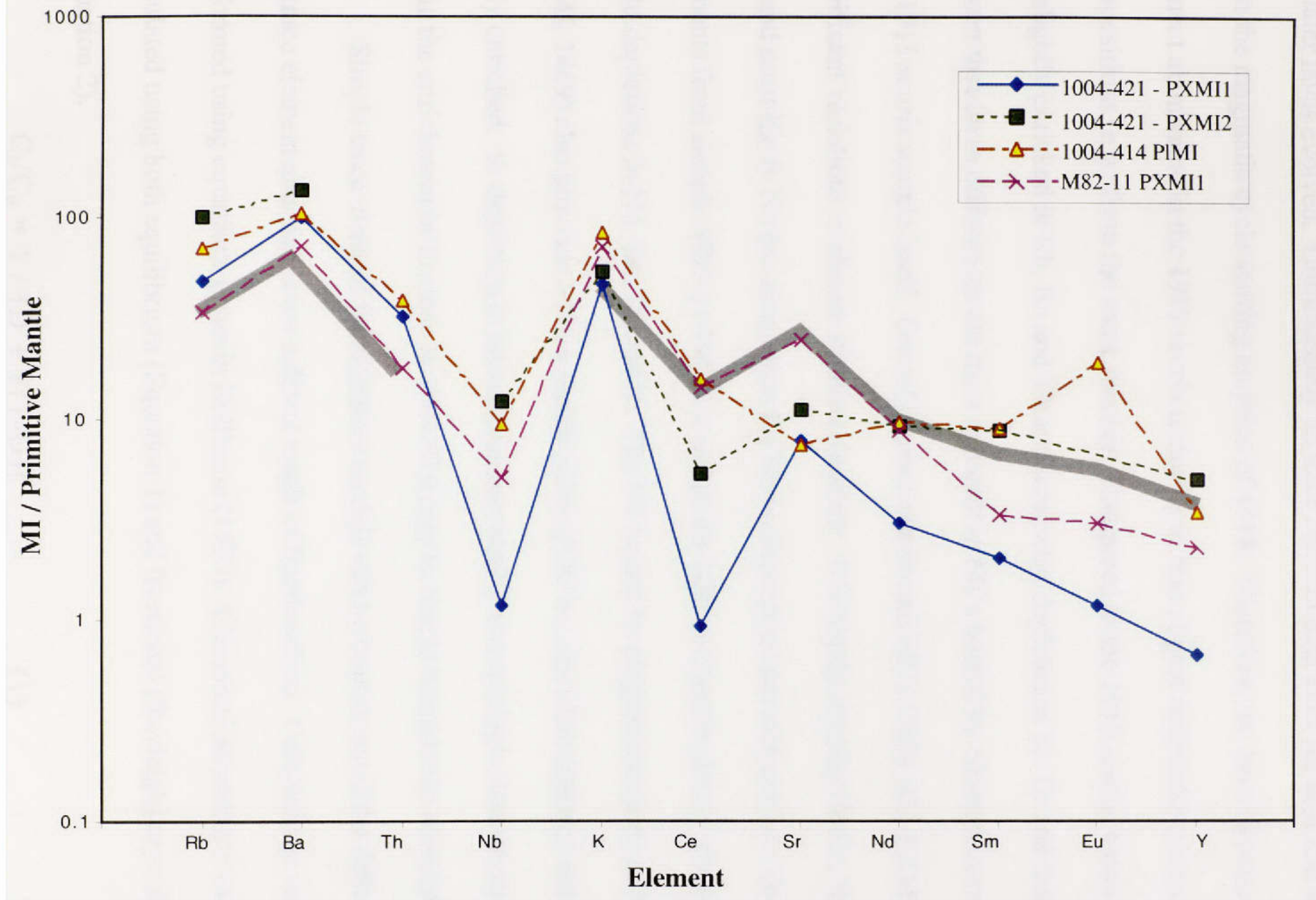

Figure 6-4: Plot of trace elements from Colima melt inclusions normalized to primitive mantle values of Sun \& McDonough (1989). Thick gray line represents trace element data for Colima lavas from 1869-1913 (Data from Luhr \& Carmichael, 1990) 
more mafic scoriaceous andesites represent new batches of primitive magma from which the later lavas evolved. Unfortunately no trace element data exist for lava and scoria from the magmatic cycle starting eruption of 1818. Therefore, we must assume that trace element abundance in the 1913 scoria is similar to that of past magmatic cycle starting compositions (e.g., from the same source). Compared to the 1913 scoria, Colima MI's are slightly enriched in $\mathrm{Rb}, \mathrm{Ba}$ and $\mathrm{Th}$ and somewhat depleted in $\mathrm{Sr}, \mathrm{Ce}$ and $\mathrm{Sm}$. It can be seen that these differences are most apparent in MI's hosted by clinopyroxene from the 1913 scoria sample itself. One of the two cpx hosted MI's (1004-421-PXMI 1) shows significant variations in almost all trace elements. It is highly depleted in $\mathrm{Ce}, \mathrm{Sm}, \mathrm{Eu}, \mathrm{Y}$, $\mathrm{Nd}$ and most likely $\mathrm{Nb}$ (no data exists for $\mathrm{Nb}$ in respective lava and scoria). Trace elements from sample M82-11-PXMI-1 match the bulk rock more closely except for slight depletions in Nd, Sm, Eu and Y. The MI hosted by plagioclase (sample 1004-414PLMI, 1869) also provides a close match although $\mathrm{Sr}$ is somewhat depleted while Eu is fairly enriched. Sr depletion in all samples is probably due to plagioclase crystallization while the enrichment in Eu seen in 1004-414 may be due to hornblende dissolution.

Simple trace element fractionation models can be used to see if the differences in the trace element abundance are a direct result of fractionation. Calculations were preformed using equations given in Rollinson (1995). Elemental abundance was calculated using both equilibrium (Equation 1) and fractional (Rayleigh) crystallization (equation 2).

$$
\begin{aligned}
& \mathrm{C}_{1} / \mathrm{C}_{0}=1 /[\mathrm{D}+\mathrm{F}(1-\mathrm{D})] \\
& \mathrm{C}_{1} / \mathrm{C}_{\mathrm{o}}=\mathrm{F}^{(\mathrm{D}-1)}
\end{aligned}
$$


Where $\mathrm{D}$ is the bulk partition coefficient (values for $\mathrm{K}_{d}$ used to calculate $\mathrm{D}$ were obtained from Rollinson, 1995), $\mathrm{F}$ is the percent of melt remaining (or inversely the proportion of crystals) $C_{L}$ is the concentration in the melt inclusion and $C_{o}$ is the concentration of the element in the initial magma. Because many of the trace elements in low abundance fractionate to apatite, one model calculates the bulk partition coefficient using a small proportion of apatite $(0.5 \%$ of total) while the other model is apatite free. The result of each of these models is shown in Figs. 6-5 a-d).

While both equilibrium and fractional models correctly predicted some trace elements these models cannot account for all the trace element concentrations measured in Colima MI's. For example Ba concentration is correctly predicted in models for all four MI's at $\mathrm{F} \leq 0.5$ (50\% crystallization or more). However, all models fail to predict the concentration of Ce and Nd in 1913 MI's. In general, 1913 MI's seem to be different for most elements than the predicted models and MI's from $1869 \& 1890$. Moreover, some elements are correctly predicted using a specific $\mathrm{F}$ value while the other elements require a different value of $\mathrm{F}$ to accurately account for their concentration. Finally, although matrix accounts for 54.6 to $74.4 \%$ of the erupted lavas from the period 1869 1913 (Luhr \& Carmichael, 1990) crystallization models require $75 \%$ crystallization to account for certain trace elements. Certainly, more data are needed to clarify these issues. 

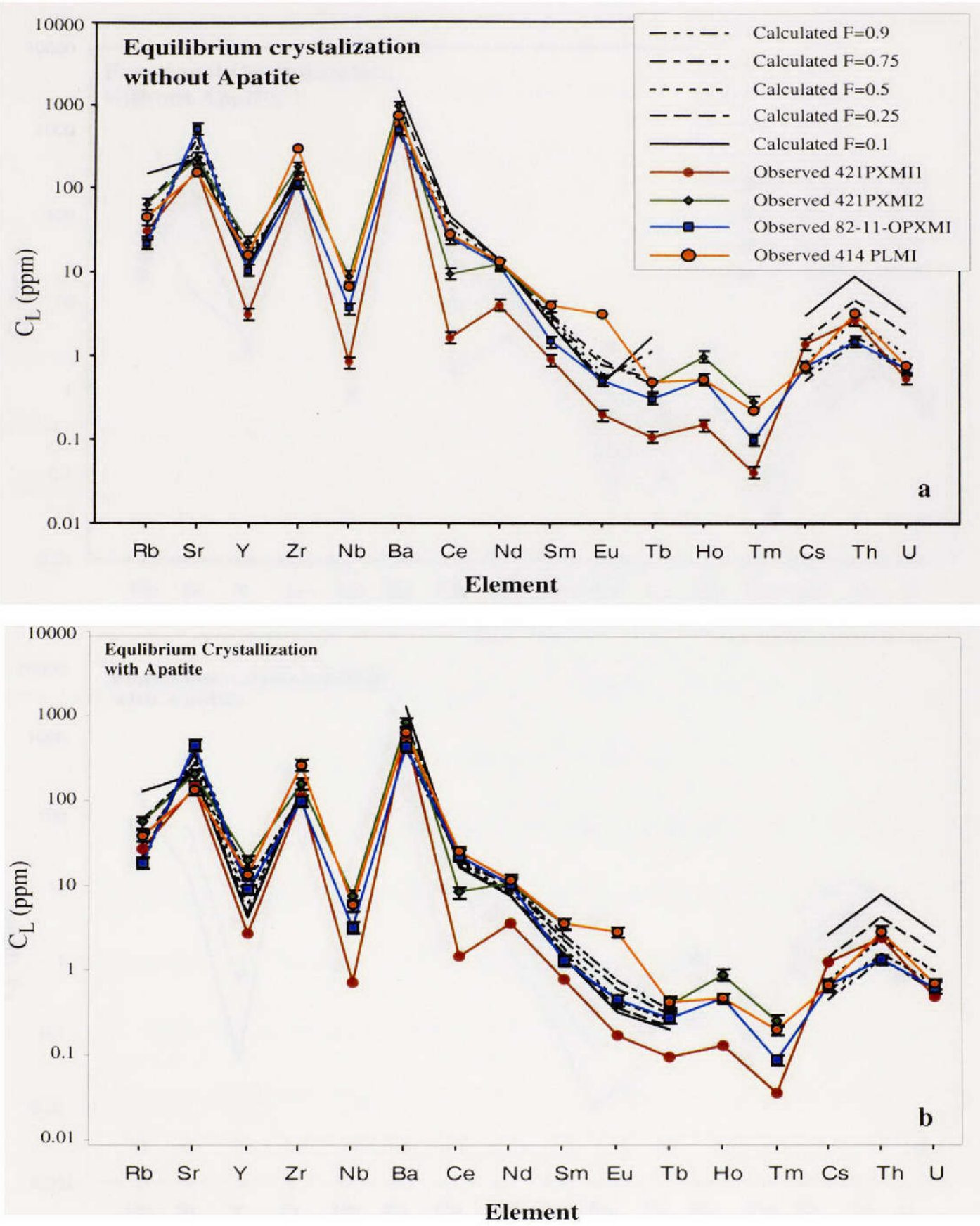

Figure 6-5 a \& b: Observer Colima melt inclusion concentrations plotted against calculated trace element compositions for varying degrees of equilibrium crystallization. Initial compositions values used in the model are from whole rock data of Luhr and Carmichael (1990) for sample 1004-421 (1913). 

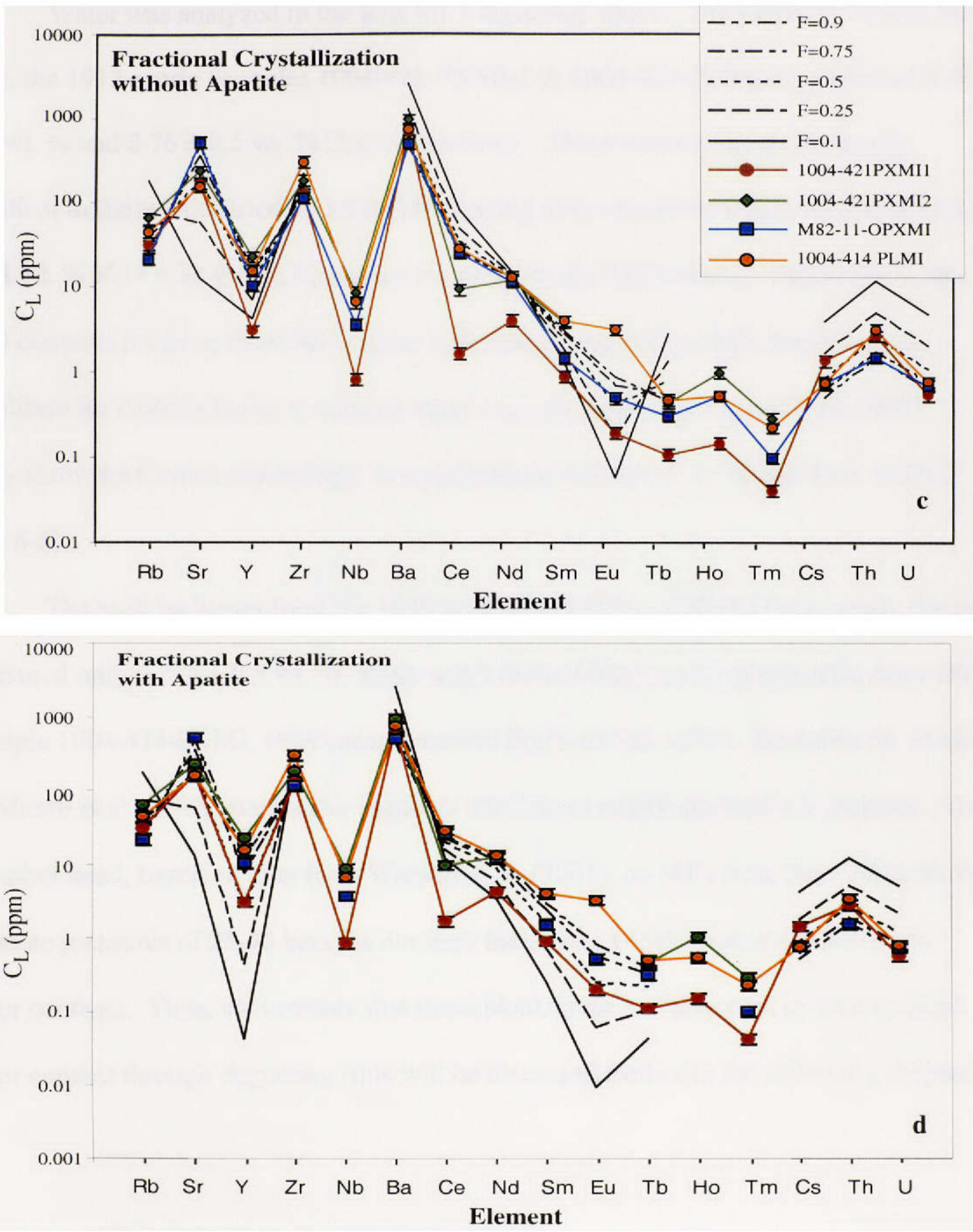

Figure 6-5 c \& d: Observer Colima melt inclusion concentrations plotted against calculated trace element compositions for varying degrees of fractional crystallization. Initial compositions values used in the model are from whole rock data of Luhr and Carmichael (1990) for sample 1004-421 (1913). 


\subsection{Water in Melt Inclusions}

Water was analyzed in the four MI's discussed above. The pyroxene hosted MI's from the 1913 scoria (samples 1004-421-PXMI-1 \& 1004-421-PXMI-2) contained $3.42 \pm$ 0.5 wt. $\%$ and $2.76 \pm 0.5$ wt. $\% \mathrm{H}_{2} \mathrm{O}$ respectively. These water contents are nearly identical to those calculated by Luhr (1992) using albite-anorthite liquid equilibrium (2.5 - 4.8 wt. $\% \mathrm{H}_{2} \mathrm{O}$ with the higher values occurring in the 1913 scoria). Furthermore, the $\mathrm{H}_{2} \mathrm{O}$ contents found in these MI's agree well with the experimentally derived phase equilibria for Colima Lavas at various water contents (Moore \& Carmichael, 1998). They show the Colima assemblage to equilibrate at between 3 wt. $\%$ and 5 wt. $\% \mathrm{H}_{2} \mathrm{O}$ (Fig 6-6).

The melt inclusion from the 1890 lava flow (M82-11 PXMI 1) was nearly dry and measured only $0.716 \pm 0.5$ wt. \%, while water in the MI hosted by plagioclase from 1869 (sample 1004-414-PLMI, 1869) near detection limits (0.394 \pm 0.5$)$. Based on the model by Moore et al. (1998) such water contents translate to nearly atmospheric pressure. On the other hand, based on data from Wardell et al. (2001), on MI's from New Zealand, we estimate pressures of 25-75 bars for our melt inclusions which contain similarly low water contents. Thus, we estimate that these block lavas had lost most of their original water content through degassing (this will be discussed further in the following chapter). 


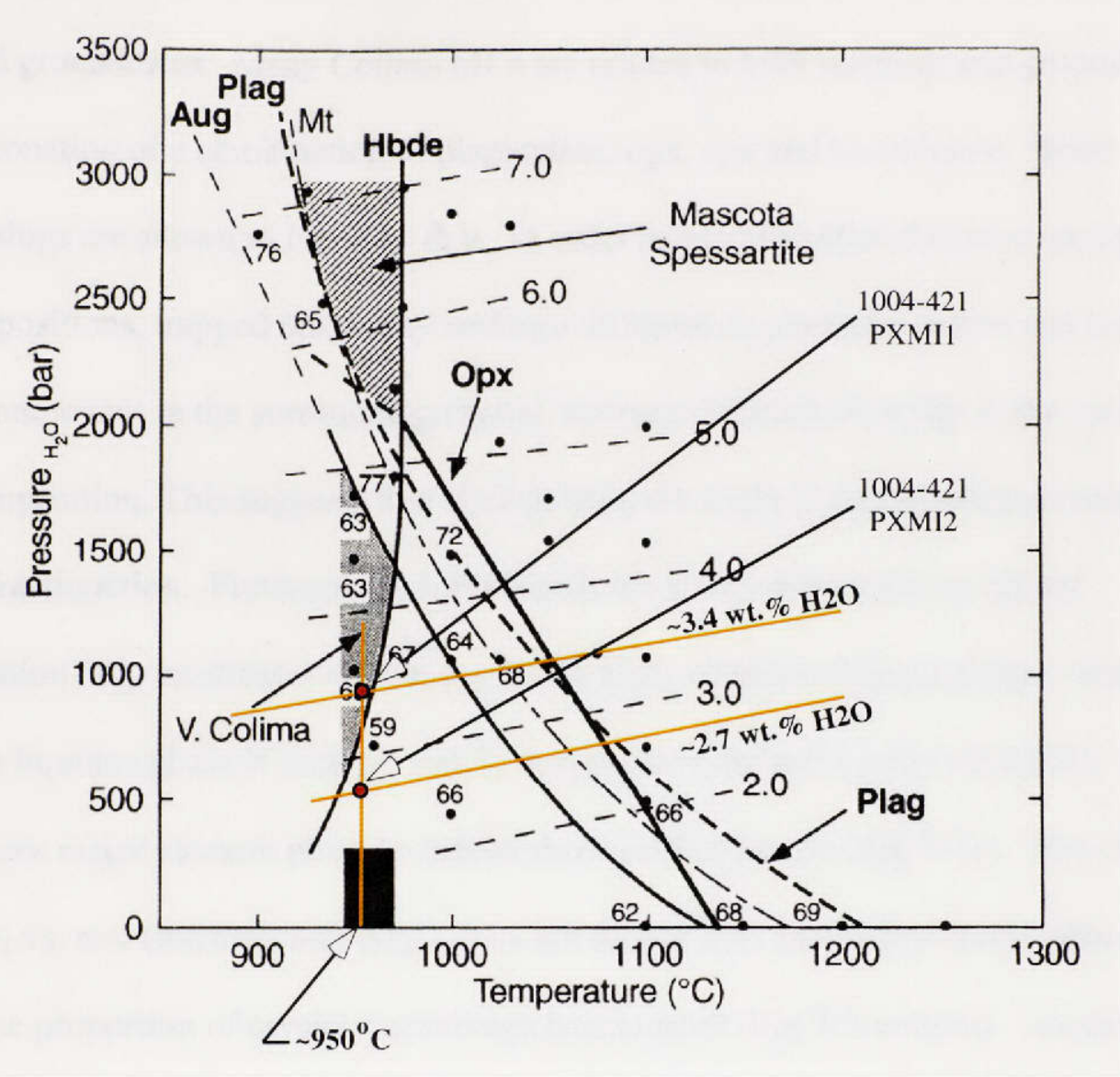

Figure 6-6: Stability fields for plagioclase, orthopyroxene, clinopyroxene, hornblende and magnetite as a function of pressure and temperature. Dashed numbered lines are water isopleths, orange lines are isopleths for measured water contents of colima MI's. Red line represents isothermal decompression for Colima MI's and red filled circles represent analyses of 1913 MI's. Also shown are average ranges of anorthite content for Colima and other Mexican plagioclases. Shaded areas represent fields of stability for phase present in Colima and other Mexican lava. Black area shows calculated temperatures of Colima lava. (Figure modified from Moore \& Carmichael, 1998) 


\section{CHAPTER 7: DISCUSSION}

In general most MI's contain higher $\mathrm{SiO}_{2}$ and lower $\mathrm{MgO}$ and $\mathrm{FeO}$ than both bulk rock and groundmass. Many Colima MI's are related to bulk magmas and groundmass by fractionation of a combination of plagioclase, opx, cpx and hornblende. These relationships are shown in Fig 7-1a \& b. In order to accommodate the large variation in MI compositions, trapped melts may undergo different degrees of reaction and loss of the solute component to the surrounding crystal, causing different diversity in the residual melt composition. This suggests that Colima MI's are trapped during different stages of crystal fractionation. Furthermore, if the trends are solely dependent on crystal fractionation they must show similar results on other element-element plots so long as 1) only one liquidus phase is present, and 2) that phase is the sole carrier of the MI. In many cases major element plots do indeed show similar results (Fig 7-1b). However, the plot $\mathrm{SiO}_{2}$ vs. raw (uncorrected) $\mathrm{Na}_{2} \mathrm{O}$ does not satisfy melt inclusions compositions no matter the proportion of crystal assemblage fractionated (Fig 7-2 bottom). As shown in chapter 5 , the deficiency seen in $\mathrm{Na}_{2} \mathrm{O}$ is mainly due to volatile element loss common to electron microprobe analysis (Nielsen \& Sigurdsson, 1981). Addition of $1.35 \mathrm{wt} \% \mathrm{Na}_{2} \mathrm{O}$ to these analyses plus the addition of $0.3 \mathrm{wt} \% \mathrm{Na}_{2} \mathrm{O}$ to plagioclase (estimated form volatility of $\mathrm{Na}$ in albite) helps rectify most of these compositions so they plot near the plagioclase fractionation line (Fig. 7-2, top). While $\mathrm{Na}$ loss in the 1 atmosphere furnace may account for the location of 1 atmosphere experimental runs on the plot of $\mathrm{SiO}_{2}$ vs. $\mathrm{Na}_{2} \mathrm{O}$ (i.e., they plot below the plagioclase fractionation line) some of the natural samples are still outside of the allowable fractionation paths. Robin et al. 

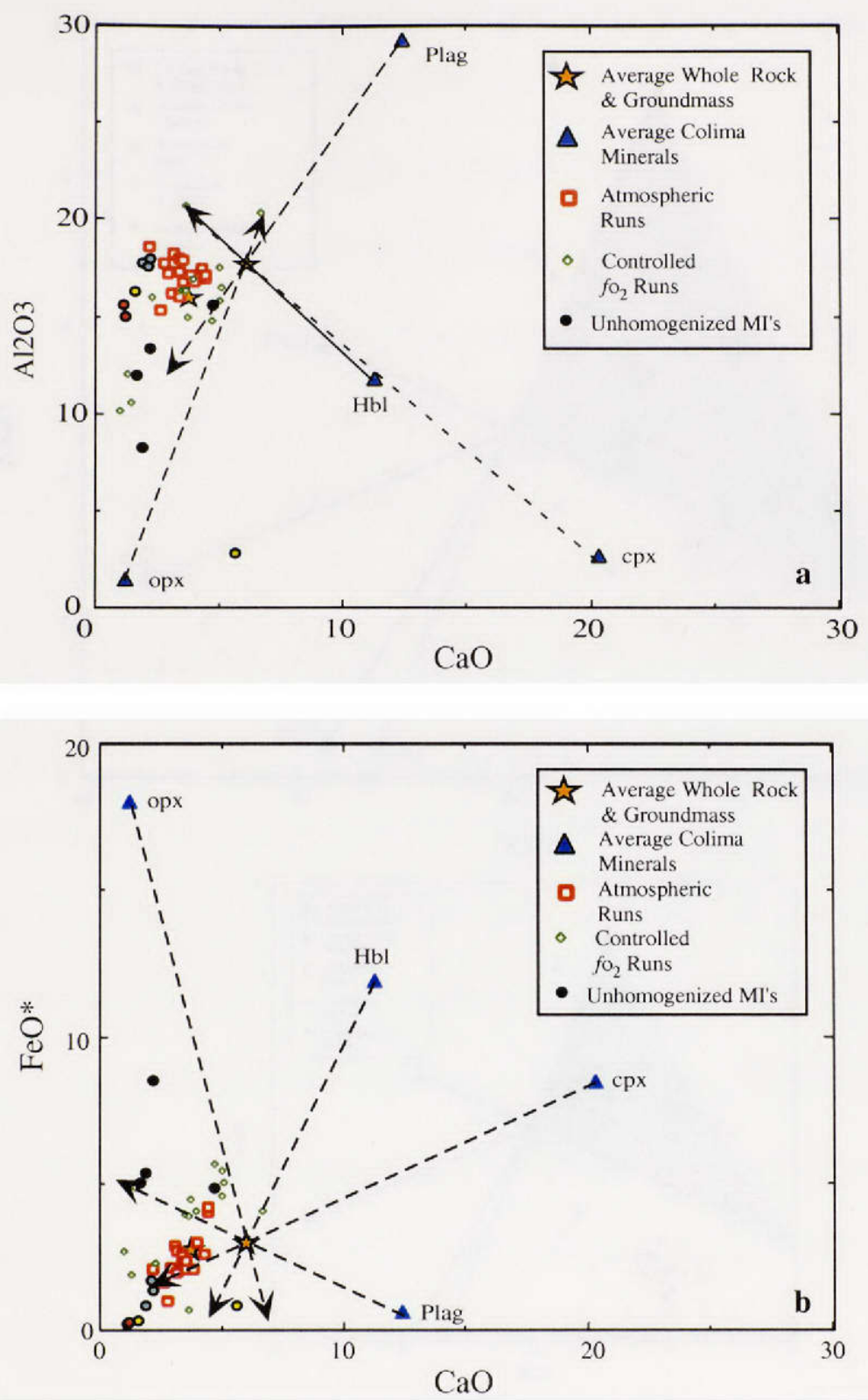

Figure 7-1: Plots of $\mathrm{Al} 2 \mathrm{O} 3$ (a) and $\mathrm{FeO}$ (b) versus $\mathrm{CaO}$. Fractionation of plagioclase and cpx dominate differentiation trends while hornblende and opx contributions are relatively small in both graphs. Lines drawn from mineral compositions represent liquid enrichment paths extending away from bulk rock. Filled circles represent unhomogenized MI's in plagioclase (full black), opx (It. blue), cpx (red) and hornblende (yellow) 

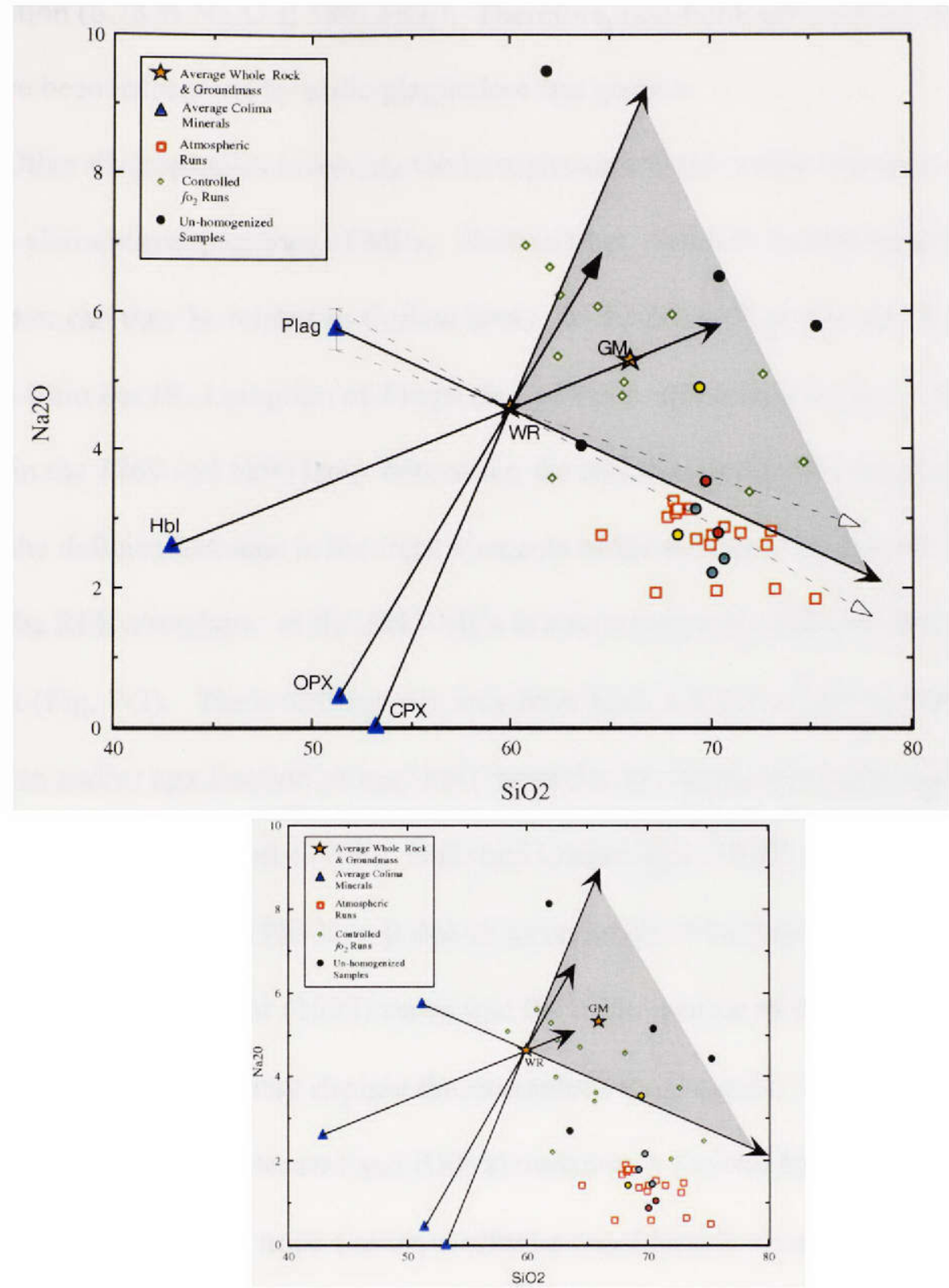

Figure 7-2: Plot of $\mathrm{Na}_{2} \mathrm{O}$ vs. $\mathrm{SiO}_{2}$. Top graph is for corrected $\mathrm{Na}_{2} \mathrm{O}$ values for all runs and plagioclase and show trends consistant with crystal fractionation from the mineral assemblage shown. Below is the same graph using raw $\mathrm{Na}_{2} \mathrm{O}$ values. Filled circles represent unhomogenized MI's in plagioclase (full black). opx (lt. blue), cpx (red) and hornblende (yellow) 
(1991) reports a single analysis of a plagioclase rim from 1913 containing a more sodic composition $\left(6.78 \% \mathrm{Na}_{2} \mathrm{O}\right.$ at $\left.58 \% \mathrm{SiO}_{2}\right)$. Therefore, non-homogenized MI compositions may have been influenced by sodic plagioclase rim growth.

Other discrepancies involving the host phases are noticeable when we consider the trace element compositions of MI's. Certain trace elements cannot be related to host crystals nor can they be related to Colima lavas. In the prior chapter it was shown that the MI's from the 1913 eruption of Fuego de Colima do not match the host scoria as well as MI's in the 1869 and 1890 lava. Moreover, the addition of apatite is not sufficient to explain the deficiencies seen in the trace elements of the pyroxene hosted MI's from 1913. The REE abundance of the $1913 \mathrm{MI}$ 's is also completely different from that of the host rock (Fig. 7-3). These deficiencies may have been a result of hornblende dissolution and/or cpx fraction or may have been due to magma mixing as described by Luhr (1992) and Robin et al. (1993). Luhr and Carmichael (1990) suggested that the more mafic nature of the 1913 lava is due to an injection of basaltic or basaltic andesite magma. Furthermore, Luhr (1992) states that the initial source of the mafic magmas is the mantle wedge, which may explain the anomalous REE trends. To be sure, further investigation of the trace element and REE abundance in Colima MI's is needed.

Despite the above, trace elements offer us considerable clues to the processes occurring at Colima. $\mathrm{H}_{2} \mathrm{O}$ and $\mathrm{K}_{2} \mathrm{O}$ are generally considered to be incompatible with respect to Colima magmas below $1 \mathrm{~kb}$ pressure (Moore \& Carmichael, 1998). Therefore, they preferentially partition into the melt phase (Dixon \& Clague, 2001). Accordingly, as $\mathrm{H}_{2} \mathrm{O}$ increases, so should incompatible element concentration. However, this is not what is observed in the present study. Water correlates negatively with $\mathrm{TiO}_{2}\left(\mathrm{r}^{2}=0.925\right), \mathrm{FeO}$ 
$\left(\mathrm{r}^{2}=0.908\right), \mathrm{CaO}\left(\mathrm{r}^{2}=0.859\right)$ and $\mathrm{Na}_{2} \mathrm{O}\left(\mathrm{r}^{2}=0.751\right)($ Fig. 7-4). Water also correlates negatively with incompatible trace elements (Ce, $\mathrm{U}$, and $\mathrm{Zr}$ ). However, $\mathrm{Cs}$ and $\mathrm{B}$ correlate positively to water (Fig. 7-5). Thus, water concentrations decrease during differentiation of the andesitic melt. $\mathrm{K}_{2} \mathrm{O}$ is also seen to inversely correlate to $\mathrm{H}_{2} \mathrm{O}$ (Chapter 6, Fig. 6-6b). This trend is not unique to Colima. Finny (2000) showed that this same relationship exists at Popocatepetl Volcano in central Mexico. A comparison of Colima MI's and MI's from Popocatepetl is shown in Figure 7-6. In the Popocatepetl study, Finny (2000) concluded that differentiation continues to occur during ascent, causing volatile and other incompatible elements to partition to the melt. However, if the ascending magma degasses during rise $\mathrm{H}_{2} \mathrm{O}$ will be preferentially lost from the differentiating melt. This would result in a negative correlation between $\mathrm{H} 2 \mathrm{O}$ and all other incompatible elements (inset in Fig. 7-4 and 7-5). Based on such behavior shown by Colima MI's, we could conclude that the trends seen in $\mathrm{H}_{2} \mathrm{O}$ versus $\mathrm{K}_{2} \mathrm{O}$ and incompatible trace elements are representative of magmatic degassing during differentiation.

Melt inclusions in clinopyroxene from 1913 contain a maximum of $3.4 \pm 0.5 \%$ $\mathrm{H}_{2} \mathrm{O}$ and a minimum of $2.7 \pm 0.5 \% \mathrm{H}_{2} \mathrm{O}$. While many studies relate water saturation to depth in basaltic and rhyolitic magmas (Burnham, 1979, Moore et al., 1998; Dixon 1995, Dunbar \& Hervig 1992, Hervig et al, 1995), few studies report $\mathrm{H}_{2} \mathrm{O}$ saturation in andesitic magmas. A recent model by Moore et al. (1995 \& 1998) calculates the solubility of water in various magmas at temperatures and pressures more applicable to Colima. Their study included a dacite from Mt. St. Helens that closely matches the composition used to calculate the Colima phase equilibria mentioned above. Moore et al. 


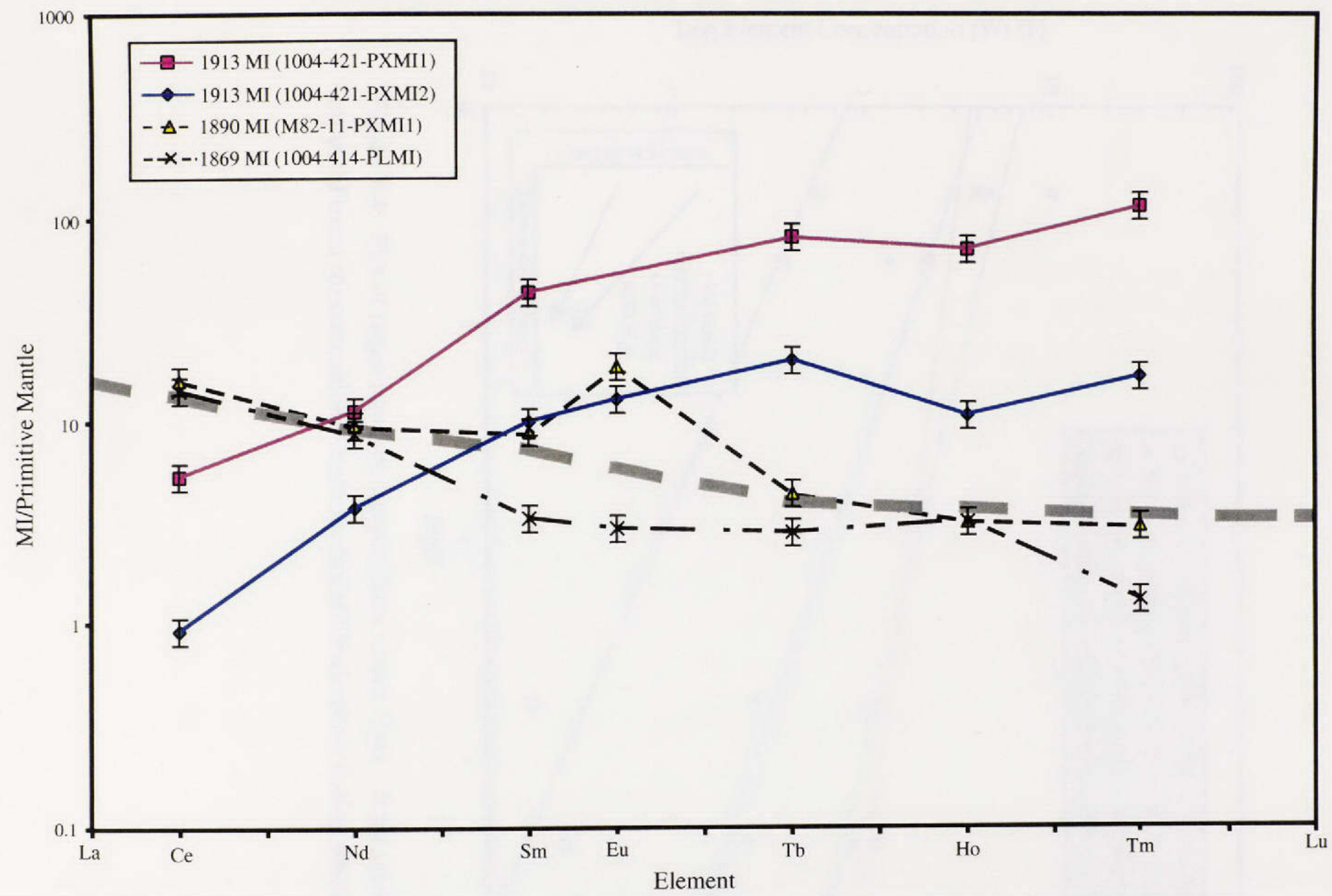

Figure 7-3: Rare earth element spidergram for Colima MI's and bulk lava of 1913 (thick dashed line). Eu anomaly in 1869 sample may be due to hornblende resorption. Trends for MI's from 1913 clearly differ from bulk rock, $1869 \mathrm{MI}$ and $1890 \mathrm{MI}$. 


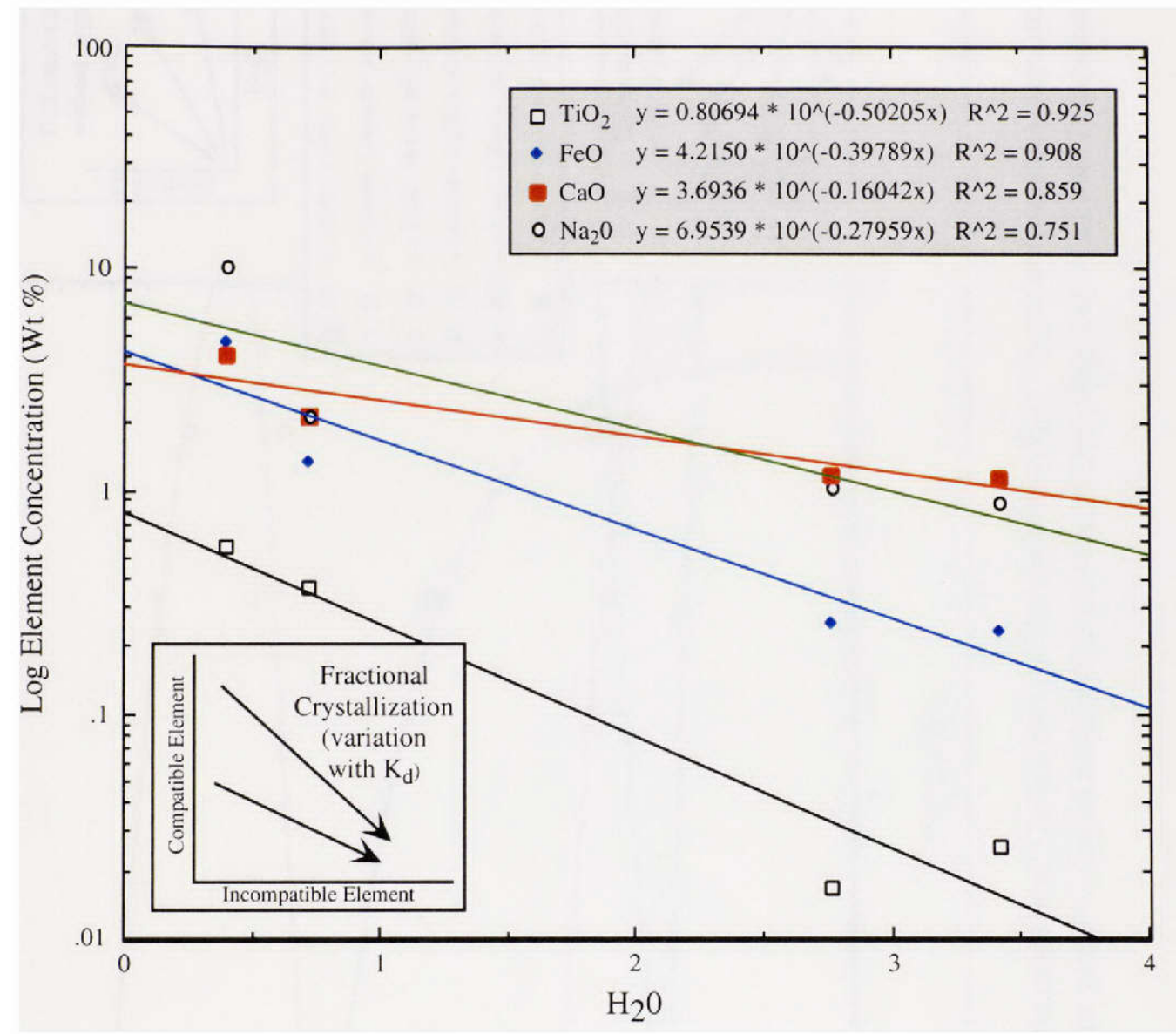

Figure 7-4: Plot of major element compositions versus $\mathrm{H}_{2} \mathrm{O}$. Inset shows expected trend for compatible versus incompatible elements during fractionation 


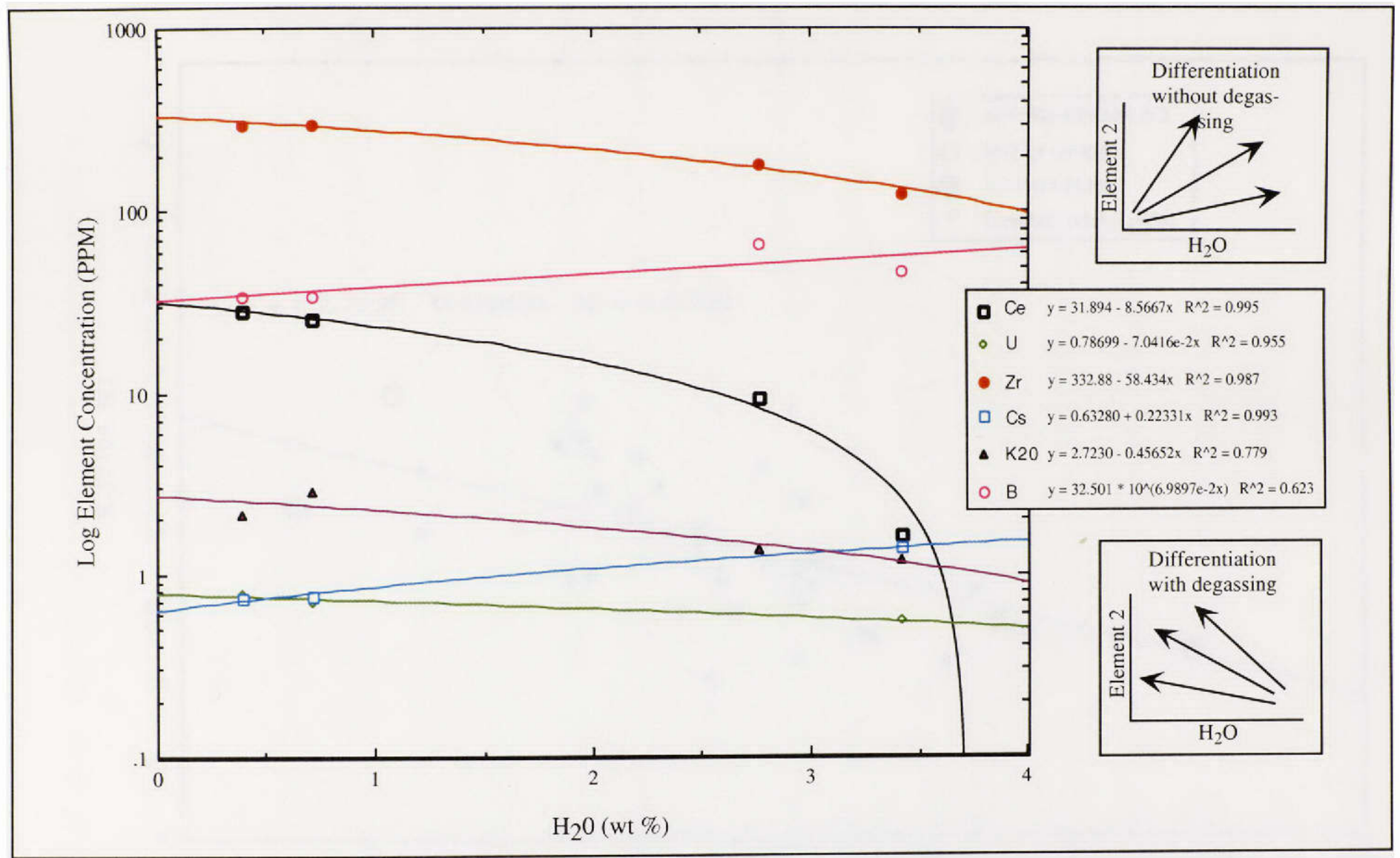

Figure 7-5: Plot of selected trace elements from Colima melt inclusions versus $\mathrm{H}_{2} \mathrm{O}$. Insets to right show expected trends for incompatible element abundance versus water for differentiation without degassing (top inset) and differentiation with degassing (bottom inset) 


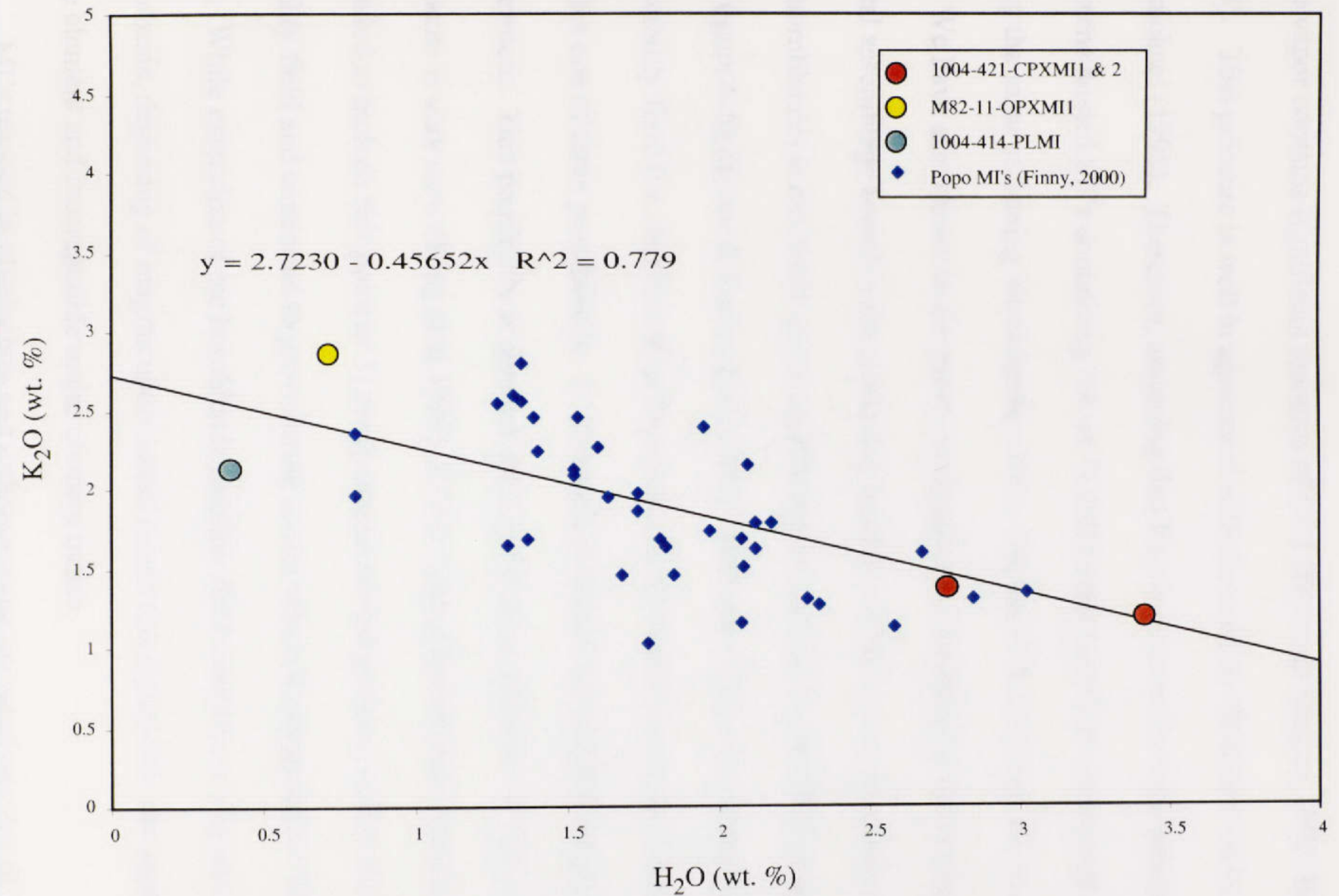

Figure 7-6: Plot of $\mathrm{H}_{2} \mathrm{O}$ versus $\mathrm{K}_{2} \mathrm{O}$ for Colima and Popocatepetl melt inclusions. Best fit line is for Colima MI's but also fits quite well the data of Finny (2000). 
(1995 \& 1998) show that andesitic melts with $3.4 \mathrm{wt} \% \mathrm{H}_{2} \mathrm{O}$ would be saturated with pure $\mathrm{H} 2 \mathrm{O}$ vapor at a pressure of 800 bars (Fig 7-7). Higher pressures would be required if the vapor contains significant amounts of CO2 (Dixon \& Stolper, 1995; Blank et al., 1993). This pressure is well in agreement with the stability field derived by Moore \& Carmichael (1998). Therefore, assuming that $\mathrm{P}_{2} \mathrm{O}$ is equal to the total pressure the pyroxene hosted MI's containing 3.4 wt. \% H2O must have been entrapped at $\sim 2.4 \mathrm{~km}$. Using the same reasoning we estimate $\sim 500 \pm 100$ bar $(1.5 \pm 0.3 \mathrm{~km})$ for the water poor MI. We have also shown in the previous chapter that the stability fields of the observed crystal assemblage found in the scoria that hosts these MI's (e.g., plagioclase, opx, cpx and hornblende) is not stable under equilibrium conditions below 600 bar and $\sim 950^{\circ} \mathrm{C}$ (see figure 6-6)(Moore \& Carmichael, 1998). Therefore if the water poor MI lies outside the stability field (i.e., has less than the maximum allowed by analytical error), then this implies one of three possibilities. 1) This melt inclusion has partially degassed after entrapment. This possibility is deemed unlikely because diffusion of $\mathrm{H}_{2} \mathrm{O}$ through pyroxene is very slow (King et al 1999). 2) The field of hornblende stability must be extended to include this point or 3 ) the pyroxene started growing within the hornblende stability field and continued to grow during ascent where it entrapped the MI with $2.7 \%$ $\mathrm{H}_{2} \mathrm{O}$. While extension of the hornblende stability field would be a very exciting hypothesis, degassing of magma upon ascent seems more plausible and agrees well with trace element and incompatible major element trends.

MI's trapped in plagioclase and orthopyroxene are relatively dry $(0.3 \pm 0.5 \%$ and $0.7 \pm 0.5 \% \mathrm{H}_{2} \mathrm{O}$ respectively). Maximal pressures, based on water saturation, are far less than those observed in the water rich MI's. It is believed that these water poor MI's 


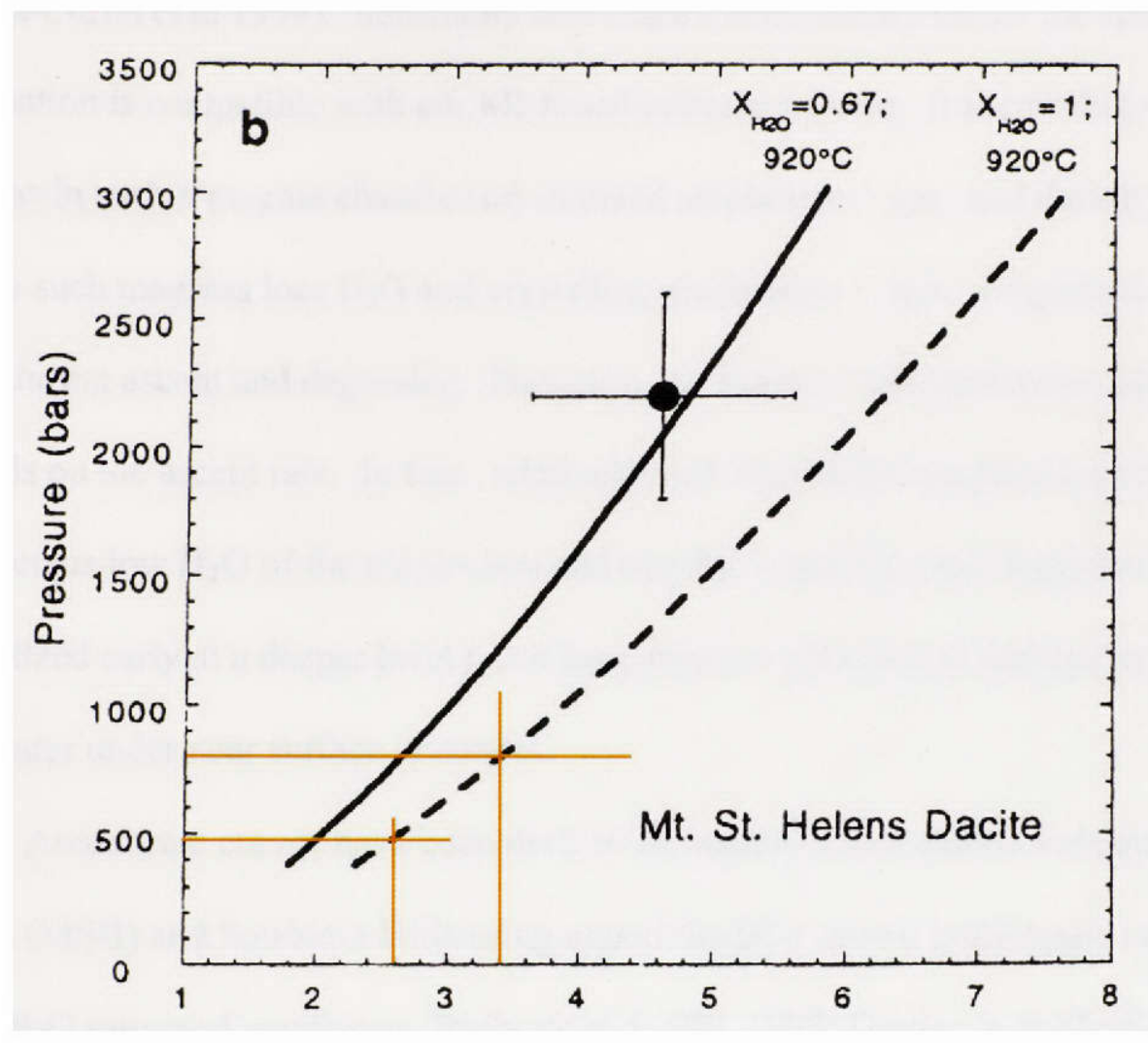

Figure 7-7: Water saturation curves derived from Moore et al. (1995 \& 1998) for dacite composition of Mt. St. Helens from Rutherford and Devine (1993). Top curve is for water undersaturated conditions while the lower (dashed) curve represents water saturated dacitic magma. Solid strait lines intersecting these curves are for Colima melt inclusions 1004-421 PXMI 1 containing $3.4 \mathrm{wt} \%$ $\mathrm{H}_{2} \mathrm{O}$ and 1004-421 PXMI 2 containing $2.7 \% \mathrm{H}_{2} \mathrm{O}$. 
likely represent degassed melts. Since these MI's occur in plagioclase and opx, this observation implies that these phases crystallized at shallow depths.

Seismic evidence suggests that a magma chamber may exist at 1-3 km depth (Núñez-Cornú et al 1994). Seismicity also occurs immediately below the surface. This information is compatible with our MI-based inference above. It seems that water rich magmas in such a magma chamber crystallized amphibole $+\mathrm{cpx}$; and during ascent to the surface such magmas lose $\mathrm{H}_{2} \mathrm{O}$ and crystallize plagioclase + opx. Amphibole also breaks down during ascent and degassing. However, the extent of the breakdown reaction depends on the ascent rate. In sum, relatively high $\mathrm{H}_{2} \mathrm{O}$ in the amphibole \& cpx hosted MI's versus low $\mathrm{H}_{2} \mathrm{O}$ of the plagioclase and opx MI's indicates that amphibole and cpx crystallized early at a deeper level $(\sim 2.4 \mathrm{~km})$, whereas plagioclase and opx crystallized much later under near surface pressures.

Ascent rate curves have been derived for andesitic and dacitic volcanoes of Mt St. Helens (MSH) and Soufriere Hills using experimentally grown hornblende oxidation rims under $\mathrm{H}_{2} \mathrm{O}$ saturated conditions (Rutherford \& Hill, 1998; Devine \& Rutherford, 1998). Note that the stability field of hornblende in Colima magma is substantially different from the MSH case despite the fact that the starting compositions for the two magmas are similar (Fig 7-8). This difference is not understood; but it is apparent that the MSH amphibole field would be incompatible with the presence of amphibole in Colima lavas. That is, the MSH phase diagram is inapplicable to Colima. Unfortunately, to date, no study has measured hornblende rim growth rates for Colima, and therefore we must assume that the measured growth rates derived by Rutherford \& Hill (1993) are applicable to Colima, which may or may not be correct in detail, but may still be useful. 
As outlined in chapter 5, hornblende rims for samples from 1869 are $\sim 15-20 \mu \mathrm{m}$ wide and average $18 \mu \mathrm{m}$ wide. Applying the MSH derived equations (Rutherford \& Hill, 1993) we obtain magma ascent times of 9 - 15 days from $2.4 \mathrm{~km}$ depth (Fig 7-9) $(\sim 8.3 \pm$ $2.8 \mathrm{~m} / \mathrm{hr})$. The 1869 sample, $1004-404$ has comparatively thick rims $(80-100 \mu \mathrm{m})$. For this sample we estimate ascent times of between 30 and 50 days $(2.0-3.3 \mathrm{~m} / \mathrm{hr})$. block lavas contain hornblende with thin rims (in M82-11 rims are 8-10 $\mu \mathrm{m}$ ) and totally resorbed hornblendes with rims that measure $200 \pm 25 \mu \mathrm{m}$ from the center of the "crystal" (JT91-68). Ascent times have been estimated for sample M82-11 to be 5 days (ascending at $\sim 20 \mathrm{~m} / \mathrm{hr}$.) while it is estimated to be a minimum of $65-120$ days $(0.83-1.5$ $\mathrm{m} / \mathrm{hr}$.) for JT91-68. Rutherford and Hill (1993) report that the onset of hornblende rim growth begins after 4 days regardless of starting temperatures and pressures used. Therefore, the 1913 scoria sample containing rim free amphibole crystals must have ascended to the surface in less than 4 days at speeds $\geq 25 \mathrm{~m} / \mathrm{hr}$. This rapid ascent rate may also help explain why the modal percentage of phenocrysts in the 1913 scoria is low. Further, if the opx grows in the upper reaches of the magmatic column fast ascent helps explain why there is little opx found in the scoria.

In sum, MI's from Colima have highly complex histories. Their water contents dictate that some were entrapped at near surface conditions while others formed at depth. Their major and trace element compositions suggest that the magmas were simultaneously differentiating and degassing during ascent. Clinopyroxene and hornblende phenocrysts appear to have crystallized early from undegassed magma, at or below $2.4 \mathrm{~km}$ while orthopyroxene, and to some extent plagioclase, grew at near surface conditions. From the growth of hornblende rims we have estimated that Colima's 
scoriaceous magmas must rise from $2.4 \mathrm{~km}$ depth to the surface at $\geq 25 \mathrm{~m} / \mathrm{hr}$. This ascent rate has a dramatic effect on both crystal content and the concentration of water in the MI. Magmas rising quickly (1913) correlate with MI's that contain more water and are associated with more violent eruptions. Those MI's with low water contents (found in eruptive products from 1869 and 1880) correspond to slow ascent rates $(<8 \mathrm{~m} / \mathrm{hr}$.), block lava flows with higher modal abundance of phenocrysts. 


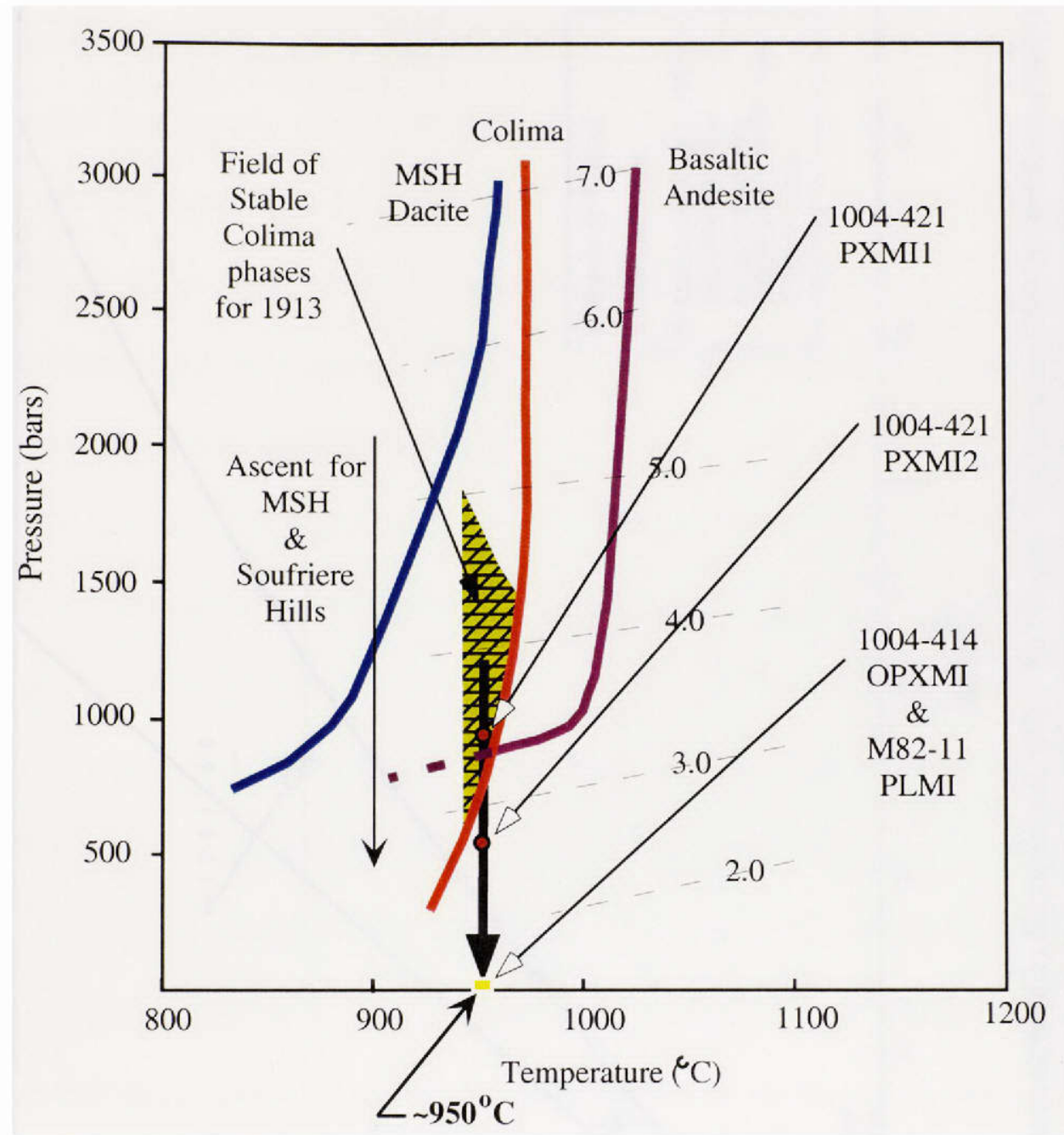

Figure 7-8: Plot of phase stability for Colima, Mt. St. Helens (MSH) and for basaltic andesite. Dashed lines represent water saturation isopleths. Arrows show isothermal decompression lines for both Colima and MSH. Also plotted are MI's analized for water (red circles and yellow squares) in relation to colima stability field shown in figure 6-6. Diagram modeled from Moore \& Carmichael (1998) and Rutherford \& Hill (1993). 


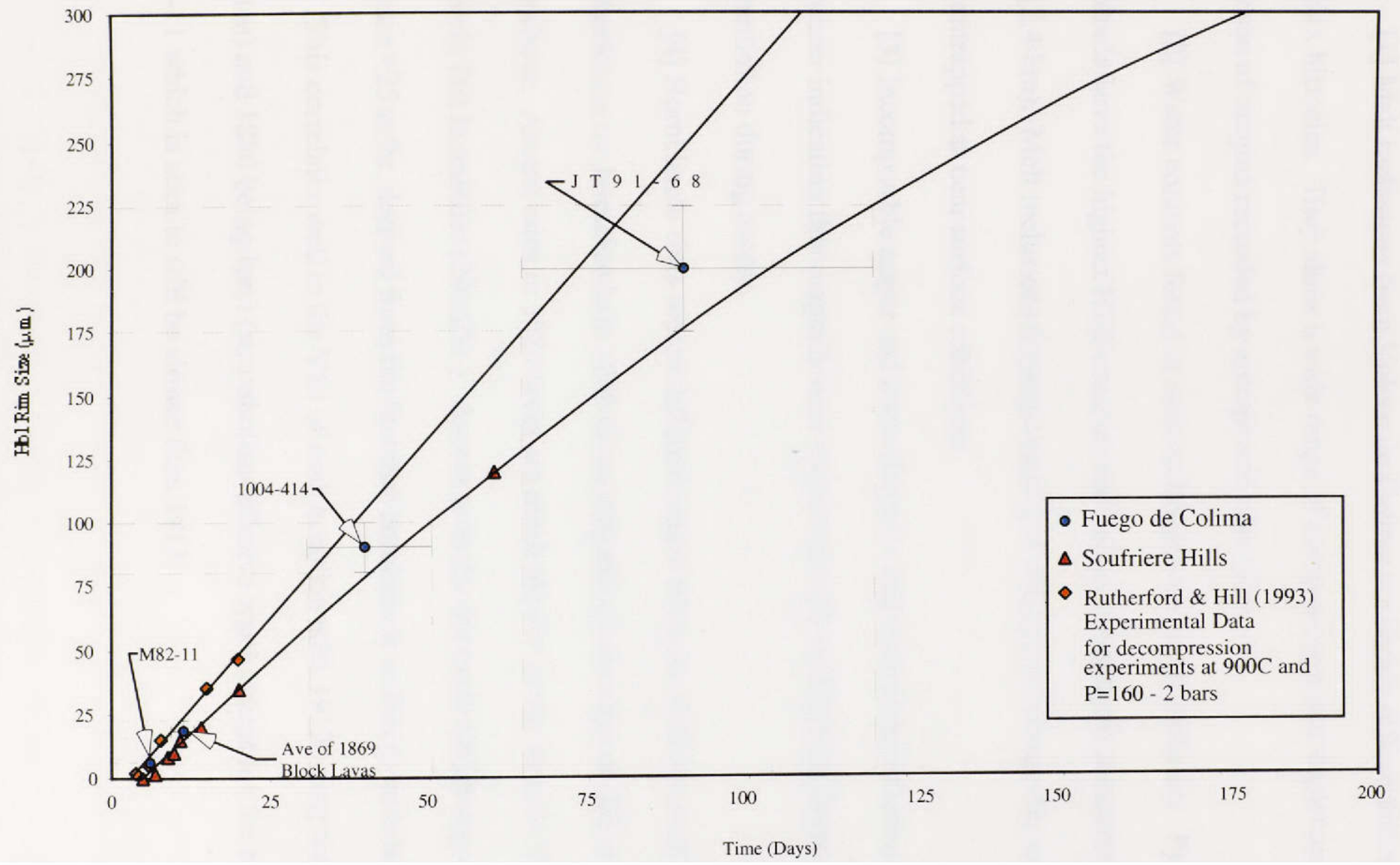

Figure 7-9: Ascent rate cruves derived by Rutherford \& Hill (1993) for Mt. St. Helens and Devine and Rutherford (1998) for Soufriere Hills volcano plotted with measured hornblend reaction rims for Fuego de Colima (this study). 


\section{CHAPTER 8: CONCLUSIONS}

[1] Melt inclusions from Volcan de Colima are highly differentiated and have complex histories. They show a wide range of compositions that depict an overall evolution of magma recorded by entrapment over time.

[2] Water contents found in melt inclusions are vastly different. Pyroxene and amphibole have the highest $\mathrm{H} 2 \mathrm{O}$ contents and reflect entrapment pressures of at least 800 bars $(2.4 \mathrm{~km})$. Melt inclusions in plagioclase and orthopyroxene are dry and must have been entrapped at near surface conditions.

[3] Incompatible major and trace elements and trace element correlate inversely with water indicating that magmas were simultaneously undergoing degassing and differentiation during ascent.

[4] Hornblende rims record different ascent rates for different eruptive events. Rim thickness for hornblende in 1869 lavas suggests ascent rates on the order of $8.3 \pm 2.8$ meters/hour. Ascent rates in 1880 lavas are much slower in one sample $(0.83-3.3 \mathrm{~m} / \mathrm{hr}$.) relatively fast in another $(20 \mathrm{~m} / \mathrm{hr}$.). Ascent rates for the cycle beginning eruption of 1913 are $>25 \mathrm{~m} / \mathrm{hr}$. derived from the fact that hornblende in this sample has no oxidation rims. This correlates well to the VEI of each eruption with 1913 being the most violent (plinian) and 1880 being least (strombolian-effusive type) except for the rapid ascent of M82-11 which is seen to still be slower than 1913. 


\section{REFERENCES}

Allan, J. F. \& Carmichael, I. S. E. (1984). Lamprophyric lavas in the Colima graben, SW Mexico. Contributions to Mineralogy and Petrology, 88, 203-216.

Bandy, W., Mortera-Gutierrez, C., Urrutia-Fucugauchi, J. \& Hilde, T. W. C. (1995). The subducted Rivera-Cocos plate boundary: Where is it, what is it, and what is its relationship to the Colima rift? Geophysical Research Letters, 22 (22), 30753078 .

Bacon, C. R., Newman, S. \& Stolper, E. (1992). Water, $\mathrm{CO}_{2}, \mathrm{Cl}$ and $\mathrm{F}$ in melt inclusions in phenocrysts from three Holocene explosive eruptions, Crater Lake, Oregon. American Mineralogist, 77, 1021-1030.

Blank, J. G., Stolper, E. M., \& Carroll, M. R. (1993). Solubilities of carbon dioxide and water in rhyolitic melt at $850 \mathrm{C}$ and 750 bars. Earth and Planetary Science Letters, $119,27-36$

Calanchi, N., Lucchini, F., Navarro-Ochoa, C. Rossi, P. L. \& Sanchez-Perez, J. (1995). Magmatic evolution of the $<<$ modern $>>$ activity of the Nevado de Colima volcano in relation to the Colima Volcanic Complex activity. Acta Volcanologia, 7 (1), $75-84$.

Campos-Enríquez, J. O. \& Alatorre-Zamora, M. A. (1998). Shallow crustal structure of the junction of the grabens of Chapala, Tepic-Zacoalco and Colima, Mexico. Geofísica Internacional, 37 (4), 263-282.

Cashman, K. V. (1993). Relationship between plagioclase crystallization and cooling rate in basaltic melts. Contributions to Mineralogy and Petrology, 113, 126-142.

Christensen, J. N., Halliday, A. N., Lee, D-C., \& Hall, C. M. (1995). In situ Sr isotopic analysis by laser ablation. Earth and Planetary Science Letters, 136, 79-85.

Christensen, J. N., Halliday, A. N. (1996). Rb-Sr ages and Nd isotopic compositions of melt inclusions from the Bishop Tuff and the generation of silicic magma Earth and Planetary Science Letters, 144, 547-561.

Cox, K. G., Bell, J. D. \& Pankhurst, R. J. (1979). The Interpretation of Igneous Rocks. George Allen \& Unwin, Ltd. London, U.K., p. 145- 175 \& 332-398

Davidson, J., Tepley, F. Palacz, Z. \& Meffan-Main (2001). Magma recharge, contamination and residence times revealed by in situ laser ablation isotopic 
analysis of feldspar in volcanic rocks. Earth and Planetary Science Letters, 184, 427-442.

De la Cruz-Reyna, S. (1993). Random patterns of occurrence of explosive eruptions at Colima volcano, Mexico. Journal of Volcanology and Geothermal Research 55, 51-68

DePaolo, D. J., (1981). Trace element and isotope effects of combined wall rock assimilation and fractional crystallization. Earth and Planetary Science Letters, $53,189-202$

Devine, J. D., Rutherford, M. J. \& Gardner, J. E. (1998). Petrologic determination of ascent rates for the 1995-1997 Soufriere Hills Volcano andesitic magma. Geophysical Research Letters, 25 (19), 3673-3676.

Devine, J. D., Murphy, M. D., Rutherford, M. J., Barclay, J., Sparks, R. S. J., Carroll, M. R., Young, S. R. \& Gardner, J. E. (1998). Petrologic evidence for pre-eruptive pressure-temperature conditions, and recent reheating, of an andesitic magma erupting at the Soufriere Hills Volcano, Montserrat, W. I.. Geophysical Research Letters, 25 (19), 3669-3672.

Dixon, J. E. \& Clague, D. A. (2001). Volatiles in basaltic glasses from Loihi Seamount, Hawaii: evidence for a relatively dry plume component. Journal of Petrology, 42, $3,627-654$.

Dixon, J. E., Stolper, E. M. \& Holloway, J. R. (1995). An experimental study of water and carbon dioxide solubilities in mid-ocean ridge basaltic liquids. Part I: calibration and solubility models. Journal of Petrology, 36 (6), 1607-1631

Dixon, J. E., Stolper, E. M. \& Holloway, J. R. (1995). An experimental study of water and carbon dioxide solubilities in mid-ocean ridge basaltic liquids. Part II: application to degassing. Journal of Petrology, 36 (6), 1633-1646

Dunbar, N. W. \& Hervig, R. L. (1992). Volatile and trace element composition of melt inclusions from the Lower Bandelier Tuff: implications for magma chamber process and eruptive style. Journal of Geophysical Research, 97(B11) 15,15115,170 .

Dunbar, N. W. \& Hervig, R. L. \& Kyle, P. R. (1989). Determination of pre-eruptive $\mathrm{H} 2 \mathrm{O}, \mathrm{F}$ and $\mathrm{Cl}$ contents of silicic magmas using melt inclusions: examples from Taupo volcanic center, New Zealand. Bulletin of Volcanology, 51, 177-184.

Elliott, T., Plank, T., Zindler, A. White, W. \& Bourdon, B. (1997). Element transport from slab to volcanic front at the Mariana arc. Journal of Geophysical Research, $102,14,991-15,019$ 
Faure, G. (1986). Principles of Isotope Geology, $2^{\text {nd }}$ Edition. John Wiley \& Sons, Inc., New York, N.Y.

Finny, M. (2000). Volatiles in melt inclusions from Popocatepetl Volcano, Mexico: implications for subduction zone process and volcanic hazards. Masters Thesis. University of Miami

Gangopadhyay, A. (2000). An experimental petrologic study of basalts from selected formations of the Deccan Traps, India. Masters Thesis., Florida International University, 26-43

Ghiorso, M. (1997). Thermodynamic models of igneous processes. Annual Review of Earth and Planetary Science 25, 221-241.

Gill, J. B. (1981). Orogenic Andesites and Plate Tectonics. Springer-Verlag, N.Y.,

Gioncada, A., Clocchiatti, R., Sbrana, A., Bottazzi, P., Massare, D. \& Ottolini, L. (1998). A study of melt inclusions at Vulcano (Aeolian Islands, Italy): insights on the primitive magmas and on the volcanic feeding system. Bulletin of Volcanology, 60,286-306.

Grove, T. L. \& Kinzler, R. J. (1986). Petrogenisis of andesites. Annual Review of Earth and Planetary Science 14, 417-454

Hervig, R. L. \& Dunbar, N. W. (1992). Cause of chemical zoning in the Bishop (California) and Bandelier (New Mexico) magma chambers. Earth and Planetary Science Letters, 111, 97-108.

Hervig, R. L. \& Dunbar, N., Westrich, H. R. \& Kyle, P. R. (1989). Pre-eruptive water content of rhyolitic magmas as determined by ion microprobe analyses of melt inclusions in phenocrysts. Journal of Volcanology and Geothermal research, 36, 293-302.

Holloway, J. R. \& Blank, J. G. (1994). Application of experimental results to C-O-H species in natural melts. Reviews in Mineralogy, 30, 187-230

Housen, B. A. \& Beck, M. E. (1999). Testing terrain transport: an inclusive approach to the Baja B.C. controversy. Geology, 27 (12), 1143-1146.

Ihinger, P. D., Hervig, R. L. \& McMillan, P. F. (1994). Analytical methods for volatiles in glasses. Reviews in Mineralogy, 30, 65-121

Johnson, M. C., Anderson, A. T. \& Rutherford, M. J. (1994). Pre-eruptive volatile contents of magmas. Reviews in Mineralogy, 30, 281-330 
Kamenetsky, V. S., Eggins, S., Crawford, A. J., Green, D. H., Gasparon, M. \& Fallon, T. J. (1998). Calcic melt inclusions in primitive olivine at 43 N MAR: evidence for melt-rock reaction/melting involving clinopyroxene-rich lithologies during MORB generation. Earth and Planetary Science Letters, 160, 115-132.

Kamenetsky, V. S., Crawford, A. J., Eggins, S., Mühe, R. (1997). Phenocryst and melt inclusion chemistry of near-axis seamounts, Valu Fa Ridge, Lau Basin: insight into mantle wedge melting and the addition of subduction components. Earth and Planetary Science Letters, 151, 205-223.

Kato, T., Ringwood, A. E. \& Irifune, T. (1988). Experimental determination of element partitioning between silicate perovskites, garnets and liquids: constraints on early differentiation of the mantle. Earth and Planetary Science Letters 89, 123-145

King, P. L., Hervig, R. L., Holloway, J. R., Vennemann, T. W. \& Righter, K. (1999). Oxy-substitution and dehydration in mantle-derived amphibole megacrysts. Geochimica et Cosmochimica Acta, 63 (21), 3635-3651.

Kinzler, R. J \& Grove, T. L. (1992). Primary magmas of mid-ocean ridge basalts: 1. Experiments and methods. Journal of Geophysical Research 97(B5) 6885-6906

Kinzler, R. J \& Grove, T. L. (1992). Primary magmas of mid-ocean ridge basalts: 2. applications. Journal of Geophysical Research 97(B5) 6907-6926.

Lee, J. \& Stern, R. J. (1998). Glass inclusions in Mariana Arc phenocrysts: a new perspective on magmatic evolution in typical intra-oceanic are. Journal of Geology, 106, 19-33.

Luhr, J. F., (1992). Slab-derived fluids and partial melting in subduction zones: insights from two contrasting Mexican volcanoes (Colima and Ceborucco). Journal of Volcanology and Geothermal Research, 54, 1-18.

Luhr, J. F. \& Carmichael, I. S. E. (1990). Geology of Volcán de Colima. Universidad Nacional Autónoma de México, México D.F., Boletín 107

Luhr, J. F. \& Carmichael, I. S. E. (1990). Petrological monitoring of cyclical eruptive activity at Volcán Colima, Mexico. Journal of Volcanology and Geothermal Research, 42, 235-260.

Luhr, J. F. \& Carmichael, I. S. E. (1982). The Colima volcanic complex, Mexico: III. Ash- and scoria-fall deposits from the upper slopes of Volcán Colima. Contributions to Mineralogy and Petrology, 80, 262-275. 
Luhr, J. F. \& Carmichael, I. S. E. (1981). The Colima volcanic complex, Mexico. Part

II. Late-Quaternary cinder cones. Contributions to Mineralogy and Petrology, 76, 127-147.

Luhr, J. F. \& Carmichael, I. S. E. (1980). The Colima volcanic complex, Mexico. Contributions to Mineralogy and Petrology, 71, 343-372.

Luhr, J. F. \& Kyser, T. K. (1989). Primary igneous analcime: the Colima minettes. American Mineralogist, 74, 216-223.

Luhr, J. F., Nelson, S. A., Allan, J. F. \& Carmichael, I. S. E. (1985). Active rifting in southwest Mexico: Manifestations of an incipient eastward spreading-ridge jump. Geology, 13, $54-57$.

Marsh, B. D. (1998). On the interpretation of crystal size distributions in magmatic systems. Journal of Petrology, 39 (4), 553-599.

Macías, J. L., Capaccioni, B., Conticelli, S., Giannini, L., Martini, M. \& Rodríguez, S. (1993). Volatile elements in alkaline and calc-alkaline rocks from the Colima graben, Mexico: constraints on their genesis and evolution. Geofisica Internacional, 32(4) 575-589.

Moore, G. \& Carmichael, I. S. E. (1998). The hydrous phase equilibria (to 3 kbar) of an andesite and basaltic andesite from western Mexico: constraints on water content and conditions for phenocryst growth. Contributions to Mineralogy and Petrology, 130, 304-319.

Moore, G., Vennemann, T \& Carmichael, I. S. E. (1998). An empirical model for the solubility of $\mathrm{H} . \mathrm{O}$ in magmas to 3 kilobars. American Mineralogist, 83, 36-42

Moore, G., Vennemann, T \& Carmichael, I. S. E. (1995). Solubility of water in magmas up to 2 kbar. Geology, 23, 1099-1102.

Nakamura, M. \& Shimakita, S. (1998). Dissolution origin and syn-entrapment compositional change of melt inclusion in plagioclase. Earth and Planetary Science Letters, 161, 119-133.

Nielsen, R. L., Michael, P. J. \& Sours-Page, R. (1998). Chemical and physical indicator of compromised melt inclusions. Geochimica et Cosmochimica Acta, 62, 831839.

Nielsen, R. L., Crum, J., Bourgeois, R., Hascall, K., Forsythe, L. M., Fisk, M. R. \& Christie, D. M. (1995). Melt inclusions in high An plagioclase from the Gorda Ridge: an example of the local diversity of MORB parent magmas. Contributions to Mineralogy and Petrology, 122, 34-50. 
Nielsen, C. H. \& Sigurdsson, H. (1981). Quantitative methods for electron microprobe analysis of sodium in natural glasses. American Mineralogist, 66, 547-552

Núñez-Cornú, F., Nava, F. A., De la Cruz-Reyna, S., Jiménez, Z., Valencia, C. \& GarcíaArthur, R. (1994). Seismic activity related to the 1991 eruption of Colima Volcano, Mexico. Bulletin of Volcanology, 56, 228-237.

Pearce, N. J. G., Westgate, J. A., Perkins, W. T., Eastwood, W. J. \& Shane, P. (1999). The application of laser ablation ICP-MS to the analysis of volcanic glass shards from tephra deposits: bulk glass and single shard analysis. Global and Planetary Change, 21, 151-171

Pearce, N. J. G., Perkins, W. T., Westgate, J. A., Gorton, M. P., Jackson, S. E. Neal, C. R. $\&$ Chenery, S. P. (1997). Compilation of published data for NIST 610 and NIST 612 partially certified reference materials including new major and trace element data. Geostandards News Letter, 115-144.

Phillpotts, A. R. (1990). Principles of Igneous and Metamorphic Petrology. Prentice Hall. Englewood Cliffs, N.J.

Righter, K. \& Carmichael, I. S. E. (1996). Phase equilibria of phlogopite lamprophyres from western Mexico: biotite-liquid equilibria and P-T estimates for biotite bearing igneous rocks. Contributions to Mineralogy and Petrology, 123, 1-21.

Robin, C. \& Potrel, A. (1993). Multi-stage magma mixing in the pre-caldera series of Fuego de Colima volcano. Geofisica Internacional, 32(4) 605-615

Robin, C., Camus, G. \& Gourgaud, A. (1991). Eruptive and magmatic cycles at Fuego de Colima volcano (Mexico). Journal of Volcanology and Geothermal Research, 45, 209-225.

Robin, C., Komorowski, J., Boudal, C. \& Mossand, P. (1990). Mixed-magma pyroclastic surge deposits associated with debris avalanche deposits at Colima volcanoes, Mexico. Bulletin Volcanologia, 52, 391-403.

Robin, C., Mossand, P., Camus, G., Cantagrel, J., Gourgaud, A., \& Vincent, P. M. (1987). Eruptive history of the Colima volcanic complex (Mexico). Journal of Volcanology and Geothermal Research, 31, 99-113.

Roedder, E. (1991). Fluid inclusion evidence for immiscibility in magmatic differentiation. Geochemica Cosmochemica Acta, 56, 5-20.

Roedder, E. (1984). Fluid Inclusions. Reviews in Mineralogy. Vol. 12. Mineralogical Society of America. 
Roedder, E. (1979) Origin and significance of magmatic inclusions. Bulletin of Mineralogy, 102, 487-510.

Rollinson, H. (1993). Using Geochemical Data: evaluation, presentation, interpretation. Addison Wesley Longman Ltd., Essex, U.K.

Roggensack, K. (2001). Sizing up crystals and their melt inclusions: a new approach to crystallization studies. Earth and Planetary Science Letters, 187, 221-237.

Rutherford, M. J. \& Devine, J. D. (1988). The May 18, 1980, eruption of Mount St. Helens 3. Stability and chemistry of amphibole in the magma chamber. Journal of Geophysical Research, 93, 11,949-11,959.

Rutherford, M. J. \& Hill, P. M. (1993). Magma ascent rates from amphibole breakdown: an experimental study applied to the 1980-1986 Mount St. Helens eruptions. Journal of Geophysical Research, 98, 19,667-19,685.

Schiano, P. \& Bourdon, B. (1999). On the preservation of mantle information in ultramafic nodules: glass inclusions within minerals versus interstitial glasses. Earth and Planetary Science Letters, 169, 173-188.

Schiano \& Clocchiatti (1994). Worldwide occurrence of silica-rich melts in subcontinental and sub-oceanic mantle minerals. Nature, 368, 621-624.

Schroeder, E., Hamester, M. \& Kaiser, M. (1998). Properties and characteristics of a laser ablation ICP-MS system for the quantitative element analysis of glasses. Applications of Surficial Science, 127-129, 292-298.

Sinton, C. W., Christie, D. M, Coombs, V. L., Nielsen, R. L. \& Fisk, M. R. (1993). Nearprimary melt inclusions in anorthite phenocrysts from the Galapagos Platform. Earth and Planetary Science Letters, 119, 527-537.

Sisson, T. W. \& Layne, G. D., (1993). $\mathrm{H}_{2} \mathrm{O}$ in basalt andesite glass inclusions from four subduction related volcanoes. Earth and Planetary Science Letters, 117, 619-635.

Smithsonian Institution (2000). Global Volcanisim Program, Volcanic Activity Report.

Sommer, M. A. (1977). Volatiles $\mathrm{H}_{2} \mathrm{O}, \mathrm{CO}_{2}$ and $\mathrm{CO}$ in silicate melt inclusions in quartz phenocrysts from the rhyolitic Bandelier air-fall and ash-low tuff, New Mexico. Journal of Geology, 85, 423-432.

Sours-Page, R., Johnson, K. T. M., Nielson, R. L. \& Karsten, J. L. (1999). Local and regional variation of MORB parent magmas: evidence from melt inclusions from 
the Endeavour Segment of the Juan de Fuca ridge. Contributions to Mineralogy and Petrology, 134, 342-363.

Sun, S. S. \& McDonough, W. F. (1989). Chemical and isotopic systematics of ocean basalts: implications for mantle composition and process. Found in Saunders A. D. \& Norry, M. J. (1989). Magmatisim in the Ocean Basins. GSA Special Publication, 42, 313-435.

Taran, Y. A., Bernard, A., Gavilanes, J. C. \& Africano, F. (2000). Native gold in mineral precipitates from high-temperature volcanic gases of Colima volcano, Mexico. Applied Geochemistry, 15, 337-346.

Tatsumi, Y. \& Eggins, S. (1995). Subduction Zone Magmatisim. Blackwell Science, Inc. Cambridge, Mass.

Thomas, J. \& Draper, G. (1998). Personal communication and field notes

Vaggelli, G., De Vivo, B. and Trigila, R. (1993). Silicate Melt inclusions in recent Vesuvius lava (1631-1944): II. Analytical chemistry. Journal of Volcanology and Geothermal Research, 58, 367-376

Verma, S. P. \& Luhr, J. F. (1993). Sr-Nd-Pb isotope and trace element geochemistry of calk-alkaline andesites from Volcán Colima, Mexico. Geofiscia Internacional, 32(4) 617-631

Vogel, T. A. \& Aines, R. (1996). Melt inclusions from chemically zoned ash flow sheets from the southwest Nevada Volcanic Field. Journal of Geophysical Research, 101 (B3), 5591-5610.

Wardell, L. J., Kyle, P. R., Dunbar, N. \& Christenson, B. (2001). White Island volcano, New Zeland: carbon dioxide and sulfur dioxide emission rates and melt inclusion studies. Chemical Geology, 177, 187-200.

Webster J. D. \& Duffield, W. A. (1991). Volatiles and lithophile elements in Taylor Creek rhyolite: constraints from glass inclusion analysis. American mineralogist, $76,1628-1645$.

Wilson, M. (1989). Igneous Petrogenisis. Unwin Hyman Ltd. London, U.K.

Zou, H. (1998). Trace element fractionation during modal and nonmodal dynamic melting and open-system melting: A mathematical treatment. Geochemica Cosmochemica Acta, 62 (11), 1937-1945. 
Calibration Run 1 (23 Jun, 1999)

\begin{tabular}{|lcc|}
\hline Depth (cm) & Control Temp. $\left({ }^{\circ} \mathbf{C}\right)$ & Reference Temp $\left({ }^{\circ} \mathbf{C}\right)$ \\
\hline 26.5 & 1000 & 998 \\
25.5 & 1000 & 1005 \\
24.5 & 1000 & 1012 \\
23.5 & 1000 & 1011 \\
22.5 & 1000 & 1013 \\
21.5 & 1000 & 1007 \\
20.5 & 1000 & 997 \\
\hline
\end{tabular}

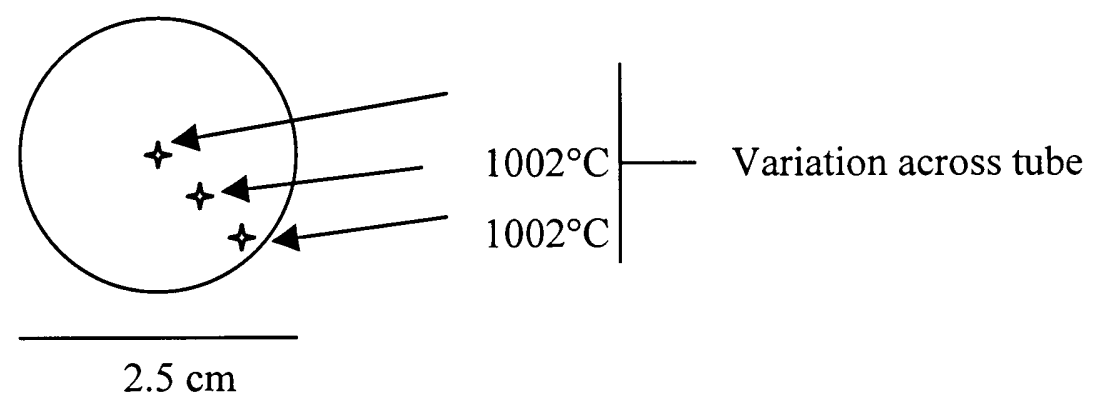

Diopside calibration at $21 \mathrm{~cm}$ depth and $1391^{\circ} \mathrm{C}(12 \mathrm{hrs} .35 \mathrm{~min}$.)

\begin{tabular}{|lll|}
\hline Time & Temp. $\left({ }^{\circ} \mathbf{C}\right)$ & Stage \\
19:55 & 989 & Stage I Ramp (Start) \\
21:50 & 1395 & Stage I Ramp \\
$21: 55$ & 1400 & Stage I Dwell (Start) \\
$22: 53$ & 1398 & Stage II Ramp \\
$23: 05$ & 1392 & Stage II Dwell (Start) \\
$23: 20$ & 1392 & Stage II Dwell \\
$23: 30$ & 1391 & Stage II Dwell \\
$11: 40$ & 1391 & Drop Quench \\
\hline
\end{tabular}

Result: Glass and crystals observed 
Calibration Run 2 (15 Dec., 1999)

\begin{tabular}{|lcc|}
\hline Depth (cm) & Control Temp. $\left({ }^{\circ} \mathbf{C}\right)$ & Reference Temp $\left({ }^{\circ} \mathbf{C}\right)$ \\
\hline 27.4 & 1150 & 1164 \\
26.2 & 1150 & 1167 \\
25.2 & 1150 & 1166 \\
24.2 & 1150 & 1161 \\
23.2 & 1150 & 1154 \\
22.7 & 1150 & 1146 \\
\hline & & \\
\hline
\end{tabular}

Diopside calibration at $22.9 \mathrm{~cm}$ depth and $1391^{\circ} \mathrm{C}(10 \mathrm{hrs} .37 \mathrm{~min}$.)

\begin{tabular}{|lll|}
\hline Time & Temp. $\left({ }^{\circ} \mathbf{C}\right)$ & Stage \\
\hline 11:23 (16 Dec. 99) & 989 & Stage I Ramp (Start) \\
13:23 & 1395 & Stage I Dwell (Start) \\
$13: 35$ & 1400 & Stage I Dwell \\
$14: 20$ & 1398 & Dwell Check \\
$14: 23$ & 1392 & Stage II Ramp (Start) \\
$14: 43$ & 1392 & Stage II Ramp \\
$14: 53$ & 1391 & Stage II Dwell (Start) \\
16:05 & 1391 & Stage II Dwell \\
10:00 (17 Dec. 99) & 1391 & Drop Quench \\
\hline
\end{tabular}

Result: Glass and crystals observed 
Calibration Run 3 (7 Aug. 2000)

\begin{tabular}{|lcc|}
\hline Depth (cm) & Control Temp. $\left({ }^{\circ} \mathbf{C}\right)$ & Reference Temp $\left({ }^{\circ} \mathbf{C}\right)$ \\
\hline 27 & 1000 & 1019 \\
26 & 1000 & 1019 \\
25 & 1000 & 1012 \\
24 & 1000 & 1008 \\
23.5 & 1000 & 999 \\
23 & 1000 & 994 \\
22 & 1000 & 980 \\
\hline
\end{tabular}

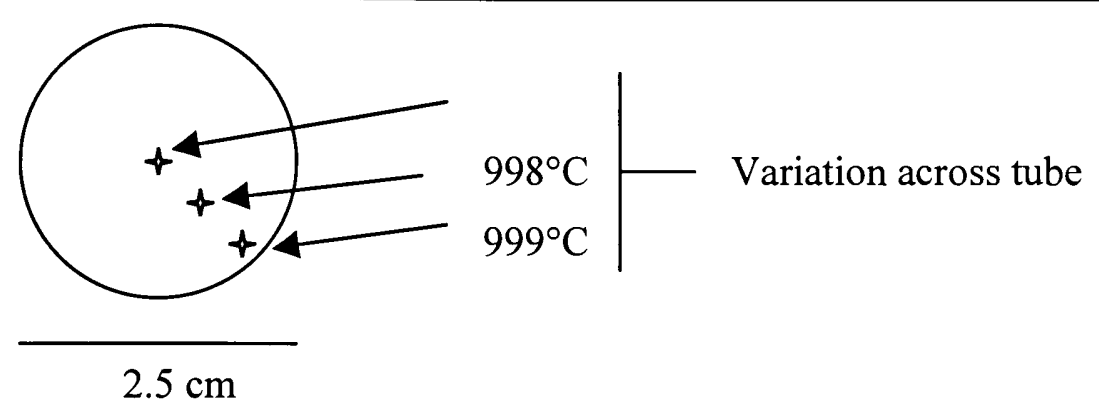

Diopside calibration at $23.5 \mathrm{~cm}$ depth and $1391^{\circ} \mathrm{C}$ (4 hrs. $14 \mathrm{~min}$.)

\begin{tabular}{|lll|}
\hline Time & Temp. $\left.^{\circ} \mathbf{C}\right)$ & Stage \\
\hline 14:16 (8 Aug. 00) & 968 & Stage I Ramp (Start) \\
14:54 & 1221 & Stage I Ramp \\
15:17 & 1388 & Stage I Dwell (Start) \\
$15: 34$ & 1399 & Stage I Dwell \\
$16: 11$ & 1399 & Stage I Dwell \\
$16: 17$ & 1398 & Stage II Ramp (Start) \\
$16: 37$ & 1386 & Stage II Dwell (Start) \\
$16: 40$ & 1391 & Stage II Dwell \\
$20: 54$ & 1391 & Drop Quench \\
\hline
\end{tabular}

Result: Glass and crystals observed 


\section{Calculation of oxygen fugacity}

Variation of Nernst Equation:

$\mathrm{Po}_{2}=0.209 \exp \left[-46.42 \mathrm{E}(\right.$ Volts $\left.) / \mathrm{T}\left({ }^{\circ} \mathrm{C}\right)\right]$

Where: $\mathrm{Po}_{2}=-\log f_{\mathrm{O}_{2}}$

Table A-1: $f_{\mathrm{O}_{2}}$ for corresponding $\mathrm{E}$ and $\mathrm{T}$ at $\mathrm{NNO}$ Buffer during experimental runs

\begin{tabular}{|lllllc|}
\hline Run & $\mathbf{T}\left({ }^{\circ} \mathbf{C}\right)$ & $\mathbf{C O}_{2}$ & $\mathbf{H}_{2}$ & $\mathbf{E}$ (Volts) & $\boldsymbol{f}_{\mathbf{2}}$ \\
\hline DI-194 CF 1 & $1140 \pm 1$ & $140 \pm 9$ & $3 \pm 2$ & $0.542 \pm 0.015$ & $-8.41 \pm 0.21$ \\
DI-194 CF 1b & $1150 \pm 1$ & $148 \pm 0$ & $30 \pm 2$ & $0.542 \pm 0.016$ & $-8.35 \pm 0.23$ \\
DI-194 CF 1b & $1150 \pm 1$ & $148 \pm 0$ & $30 \pm 2$ & $0.542 \pm 0.000$ & $-8.35 \pm 0.00$ \\
DI 194 CF 2 & $1130 \pm 1$ & $148 \pm 0$ & $2 \pm 1$ & $0.562 \pm 0.004$ & $-8.75 \pm 0.06$ \\
DI-194 CF 3 & $1120 \pm 1$ & $147 \pm 1$ & $3 \pm 1$ & $0.562 \pm 0.011$ & $-8.81 \pm 0.15$ \\
DI-194 CF 4 & $1110 \pm 1$ & $147 \pm 9$ & $17 \pm 8$ & $0.632 \pm 0.001$ & $-9.89 \pm 0.01$ \\
DI-194 CF 5 & $1100 \pm 1$ & $147 \pm 1$ & $8 \pm 4$ & $0.590 \pm 0.024$ & $-9.34 \pm 0.35$ \\
DI-194 CF 6 & $1090 \pm 1$ & $148 \pm 9$ & $33 \pm 3$ & $0.570 \pm 0.008$ & $-9.11 \pm 0.11$ \\
DI-194 CF 6b & $1090 \pm 1$ & $150 \pm 0$ & $0.5 \pm 0.5$ & $0.571 \pm 0.003$ & $-9.12 \pm 0.04$ \\
DI-194 CF 7 & $1080 \pm 1$ & $147 \pm 0$ & $1.5 \pm 1.5$ & $0.575 \pm 0.008$ & $-9.25 \pm 0.18$ \\
DI-194 CF 7b & $1080 \pm 1$ & $145 \pm 2$ & $0.5 \pm 0.5$ & $0.575 \pm 0.084$ & $-9.24 \pm 1.25$ \\
\hline
\end{tabular}


APPENDIX B

\section{Standard Compositions}

Table B-1: Compositions of SPI standard used for EPMA calibration and analyses.

\begin{tabular}{|c|c|c|c|c|c|c|}
\hline \multicolumn{7}{|c|}{ Standard compositions from SPI-2753 } \\
\hline & Obsidian & Albite & Diopside & Magnetite & Rhodenite & Rutile \\
\hline $\mathrm{SiO} 2$ & 73.94 & 68.52 & 55.37 & & 45.98 & \\
\hline $\mathrm{TiO} 2$ & 0.1 & & 0.08 & & & 100 \\
\hline $\mathrm{Al} 2 \mathrm{O} 3$ & 13.11 & 19.54 & 0.09 & & & \\
\hline $\mathrm{FeO}$ & 1.72 & & 0.05 & $99.8^{*}$ & 1.55 & \\
\hline $\mathrm{MnO}$ & 0.06 & & 0.05 & & 37.66 & \\
\hline $\mathrm{MgO}$ & 0.07 & & 18.62 & & 0.87 & \\
\hline $\mathrm{CaO}$ & 0.76 & 0.13 & 25.73 & & 6.4 & \\
\hline $\mathrm{Na} 2 \mathrm{O}$ & 4.06 & 11.59 & & & & \\
\hline $\mathrm{K} 2 \mathrm{O}$ & 5.04 & 0.22 & & & & \\
\hline
\end{tabular}

${ }^{*} \mathrm{Fe}^{+2}$ as $\mathrm{FeO}(31.03 \%), \mathrm{Fe}^{+3}$ as $\mathrm{Fe}_{2} \mathrm{O}_{3}(68.76 \%)$ 


\section{APPENDIX C \\ Detailed petrography of lava samples}

\section{9 "Volcancito" Samples}

Samples 1004-414 and DI-194 are both from the 1869 flow of the Volcancito. They contain approximately $20 \%$ plagioclase phenocrysts $10 \%$ oxyhornblende, $3 \%$ opx and cpx phenocrysts. Generally plagioclase laths are zoned and glomerophorpyritic. Laths measure 1-3 mm. Anorthite content measured by the Michel-Lévy method ranges from $\mathrm{An}_{64}$ to $\mathrm{An}_{73}$ in 1004-414 (average $\mathrm{An}_{70}$ ) and $\mathrm{An}_{45}$ to $\mathrm{An}_{75}$ in DI-194 (average $\left.\mathrm{An}_{64}\right)$. Hornblende is typified by simple twinning, mild zoning and clean margins. Orthopyroxene and clinopyroxene are generally euhedral and phenocrysts measure 1-3 $\mathrm{mm}$.

$1004-407$ is similar to the above. Plagioclase is present and accounts for $10-20 \%$ of the sample. Anorthite ranges from $\mathrm{An}_{38}$ to $\mathrm{An}_{71}$ (average $\mathrm{An}_{63.5}$ ). Large hornblende crystals are present (5\%) and display opacite rims. Minor amounts of pyroxenes can be seen as small $(<0.2 \mathrm{~mm})$ euhedral grains and total $1-2 \%$.

\section{Samples}

M82-11 is very similar to the 1869 samples with the exception of hornblende. Hornblende is nearly absent in this sample. Relic opacite rims have degraded as well and measure less than $0.5 \mathrm{~mm}$. In many places and oxide phase and CPX are all that remains 
of the original hornblende. Plagioclase contents range from $\mathrm{An}_{33}$ to $\mathrm{An}_{72}$ (average $\left.\mathrm{An}_{63.5}\right)$.

Sample JT91-68 was also collected from the 1890 flow. It contains $\sim 20 \%$ plagioclase, $2-3 \%$ orthopyroxene and $1 \%$ clinopyroxene. Approximately $3 \%$ of the sample is the oxidized relic of hornblendes. Most large phenocrysts of plagioclase have mottled cores surrounded by a zone of melt inclusions. Smaller plagioclase tends to be mildly zoned or not zoned and do not have mottled cores or abundant MI's. Anorthite content distribution in this sample is bi-modal. One group centers at $\mathrm{An}_{39}$ (5 grains) while the other group is $\mathrm{An}_{71}$ (4 grains). Pyroxenes are twinned and tend to cluster.

\section{Sample}

Sample 1004-421 is from the 1913 pyroclast flow deposit. It also contains $20 \%$ plagioclase, with lesser amounts of hornblende and pyroxenes. Plagioclase ranges from $\mathrm{An}_{33}-\mathrm{An}_{76}$ (average $\mathrm{An}_{62}$ ). Hornblende shows opacite rim textures and is generally not twinned as seen before. Orthopyroxene is anhedral and generally measures less than 2 $\mathrm{mm}$. Small CPX clusters are prevalent throughout the thin section and cpx is often twinned. 
Table C-1 - Optic petrography of unhomogenized whole rock thin sections.

\begin{tabular}{|c|c|c|c|}
\hline Sample \# & Year of flow & Mode (norm. to $100 \%$ ) & Ml Information \\
\hline $\mathrm{DI}-194$ & 1869 & $\mathrm{Pl}_{20.0}, \mathrm{cpx}_{1.5}, \mathrm{opx}_{1.0} \mathrm{hbl}_{10}$ & $\begin{array}{l}\text { Abundant rectangular MI's in plag. } \\
\text { cores. Rare MI's in Hbl and pyroxenes }\end{array}$ \\
\hline JT91-68 & 1869 & $\mathrm{Pl}_{20.0} \mathrm{cpx}_{2.0}$ opx ${ }_{1.0} \mathrm{hbl}_{0.1}$ & $\begin{array}{l}\text { Abundant rectangular MI's in plag. } \\
\text { cores and diamond shaped to oval MI's } \\
\text { in pyroxenes }\end{array}$ \\
\hline $1004-404$ & 1869 & $\mathrm{Pl}_{18.6} \mathrm{cpx}_{1.4} \mathrm{opx}_{0.9} \mathrm{hbl}_{7.4}$ & $\begin{array}{l}\text { Abundant rectangular MI's in plag. } \\
\text { cores }\end{array}$ \\
\hline $1004-407$ & 1869 & $\mathrm{Pl}_{20.2} \mathrm{cpx}_{1.4} \mathrm{opx}_{0.9} \mathrm{hbl}_{4.0}$ & $\begin{array}{l}\text { Rare oval MI's in pyroxenes } \\
\text { Abundant MI's in plag. cores } \\
\text { Rare diamond shaped to oval MI's in } \\
\text { Hbl and pyroxenes }\end{array}$ \\
\hline M82-11 & 1890 & $\mathrm{Pl}_{23.6} \mathrm{cpx}_{1.9}$ opx $x_{0.8} \mathrm{hbl}_{3.2}$ & $\begin{array}{l}\text { Abundant oval and rectangular MI's in } \\
\text { Plag. rims and cores and throughout } \\
\text { pyroxenes }\end{array}$ \\
\hline $1004-421$ & 1913 & $\mathrm{Pl}_{12.5} \mathrm{cpx}_{2.6} \mathrm{opx}_{1.6} \mathrm{hbl}_{3.6}$ & $\begin{array}{l}\text { Abundant MI's in plag. throughout } \\
\text { Rare scattered diamond shaped to oval } \\
\text { MI's in } \mathrm{Hbl} \text { and pyroxenes }\end{array}$ \\
\hline Col 9D & 1979 & $\mathrm{Pl}_{30.1} \mathrm{cpx}_{1.8}$ opx $2.9 \mathrm{hbl}_{0.1}$ & $\begin{array}{l}\text { Abundant MI's in plag. rims } \\
\text { Rare scattered MI's in pyroxenes }\end{array}$ \\
\hline Col 30 & 1982 & $\mathrm{Pl}_{28.0} \mathrm{cpx}_{5.2} \mathrm{opx}_{2.4} \mathrm{hbl}_{0.5}$ & $\begin{array}{l}\text { Abundant MI's in plag. rims extremely } \\
\text { abundant MI's throughout pyroxenes }\end{array}$ \\
\hline
\end{tabular}

Data for 1004 samples, Col samples and M82-11 is from point analysis done by Luhr and Carmichael (1990). Data for D1-194 and JT 91-68 is from estimated visual comparison to Philpotts (1989). Melt inclusion information from optical inspection. 


\section{APPENDIX D}

Table D-1: Individual point analyses for experimentally homogenized MI's from sample DI-194 runs $3\left(1200^{\circ} \mathrm{C}\right)$ and $4\left(1150^{\circ} \mathrm{C}\right)$.

\begin{tabular}{|c|c|c|c|c|c|c|c|c|c|c|}
\hline Spot/line & $\mathrm{SiO} 2$ & $\mathrm{TiO} 2$ & $\mathrm{~A} 12 \mathrm{O} 3$ & $\mathrm{FeO}^{*}$ & $\mathrm{MnO}$ & $\mathrm{MgO}$ & $\mathrm{CaO}$ & $\mathrm{Na} 2 \mathrm{O}$ & $\mathrm{K} 2 \mathrm{O}$ & Total \\
\hline Spot 5 & 73.148 & 0.455 & 18.684 & 2.118 & 0.049 & 0.613 & 2.139 & 0.657 & 1.170 & 99.033 \\
\hline Spot 9 & 70.223 & 0.508 & 16.066 & 2.610 & 0.070 & 0.774 & 3.342 & 0.616 & 1.531 & 95.740 \\
\hline Spot 10 & 75.204 & 0.380 & 15.406 & 1.669 & 0.084 & 0.429 & 2.547 & 0.503 & 1.486 & 97.708 \\
\hline $184 \mathrm{G}$ & 66.760 & 0.687 & 17.596 & 4.415 & 0.156 & 2.110 & 4.409 & 0.815 & 1.355 & 98.303 \\
\hline $185 \mathrm{G}$ & 62.817 & 0.633 & 17.706 & 4.115 & 0.087 & 2.064 & 4.395 & 1.490 & 1.252 & 94.559 \\
\hline $202 \mathrm{G}$ & 72.003 & 0.402 & 19.657 & 2.814 & 0.040 & 0.737 & 3.087 & 1.996 & 1.440 & 102.176 \\
\hline $216 \mathrm{G}$ & 66.113 & 0.607 & 16.399 & 3.997 & 0.101 & 1.828 & 4.347 & 1.367 & 1.212 & 95.971 \\
\hline $219 G$ & 67.584 & 0.597 & 16.735 & 4.108 & 0.090 & 1.783 & 4.390 & 0.395 & 1.231 & 96.913 \\
\hline $222 \mathrm{G}$ & 73.659 & 0.463 & 14.328 & 3.098 & 0.069 & 0.808 & 2.924 & 1.814 & 1.592 & 98.755 \\
\hline $224 \mathrm{G}$ & 66.971 & 0.415 & 18.002 & 2.927 & 0.096 & 0.841 & 2.768 & 0.641 & 1.502 & 94.163 \\
\hline $226 \mathrm{G}$ & 69.457 & 0.421 & 17.065 & 3.406 & 0.042 & 0.898 & 2.876 & 1.593 & 1.630 & 97.388 \\
\hline $227 \mathrm{G}$ & 71.653 & 0.433 & 14.802 & 3.179 & 0.120 & 0.901 & 3.098 & 1.770 & 1.631 & 97.587 \\
\hline $229 \mathrm{G}$ & 72.464 & 0.410 & 15.396 & 2.958 & 0.061 & 0.733 & 3.508 & 0.999 & 1.254 & 97.783 \\
\hline $239 G$ & 72.370 & 0.776 & 17.996 & 2.969 & 0.090 & 0.904 & 2.826 & 1.528 & 1.629 & 101.088 \\
\hline $240 \mathrm{G}$ & 72.954 & 0.515 & 16.912 & 2.823 & 0.109 & 0.849 & 2.885 & 0.246 & 1.288 & 98.581 \\
\hline $241 G$ & 68.408 & 0.406 & 18.528 & 2.439 & 0.011 & 0.601 & 3.720 & 2.012 & 1.639 & 97.764 \\
\hline $242 \mathrm{G}$ & 63.370 & 0.531 & 18.721 & 2.593 & 0.035 & 0.859 & 5.770 & 2.402 & 1.269 & 95.550 \\
\hline $280 \mathrm{G}$ & 68.878 & 0.491 & 17.992 & 2.139 & 0.064 & 0.854 & 3.474 & 1.808 & 1.094 & 96.794 \\
\hline $281 G$ & 69.208 & 0.463 & 18.027 & 2.377 & 0.056 & 0.794 & 3.333 & 1.379 & 1.174 & 96.811 \\
\hline $282 \mathrm{G}$ & 67.811 & 0.498 & 17.215 & 2.137 & 0.117 & 0.651 & 3.786 & 1.694 & 1.089 & 94.998 \\
\hline $283 \mathrm{G}$ & 70.006 & 0.346 & 16.845 & 2.427 & 0.083 & 0.780 & 3.483 & 1.427 & 1.169 & 96.566 \\
\hline $284 G$ & 72.976 & 0.383 & 17.772 & 1.026 & 0.064 & 0.892 & 2.753 & 1.497 & 1.114 & 98.477 \\
\hline $285 G$ & 70.642 & 0.500 & 17.785 & 2.004 & 0.039 & 0.820 & 3.085 & 1.535 & 1.098 & 97.508 \\
\hline $286 \mathrm{G}$ & 69.893 & 0.461 & 17.253 & 2.155 & 0.075 & 0.526 & 2.853 & 1.276 & 1.201 & 95.693 \\
\hline $287 \mathrm{G}$ & 68.302 & 0.488 & 17.394 & 2.554 & 0.025 & 0.624 & 3.356 & 1.794 & 1.181 & 95.718 \\
\hline $288 \mathrm{G}$ & 68.174 & 0.390 & 17.508 & 2.658 & 0.106 & 0.874 & 4.224 & 1.740 & 1.165 & 96.839 \\
\hline
\end{tabular}

Analysis performed on an ARL SEMQ microprobe at Florida International University. Analytical conditions were $15 \mathrm{kV}$ and $10 \mathrm{nA}$ using a point beam. Count times were 10 seconds for each element 
Table D-2: Individual point analyses for controlled fugacity runs

\begin{tabular}{|c|c|c|c|c|c|c|c|c|c|c|}
\hline & $\mathrm{SiO} 2$ & TiO2 & $\mathrm{A} / 203$ & $\mathrm{FeO}^{*}$ & $\mathrm{MnO}$ & MgO & $\mathrm{CaO}$ & $\mathrm{Na} 2 \mathrm{O}$ & K2O & total \\
\hline DI194CF1b.2a & 60.220 & 0.426 & 16.110 & 4.250 & 0.088 & 1.427 & 4.650 & 4.130 & 1.700 & 93.001 \\
\hline D1194CF1b.2b & 65.700 & 0.441 & 16.310 & 3.970 & 0.064 & 1.213 & 3.460 & 3.610 & 1.900 & 96.668 \\
\hline DI194CF1b.2c & 64.960 & 0.335 & 16.690 & 3.960 & 0.070 & 1.191 & 3.520 & 4.030 & 1.800 & 96.556 \\
\hline DI194CF 1b.2c-pt2 & 65.640 & 0.445 & 16.330 & 3.920 & 0.021 & 1.244 & 3.600 & 3.410 & 1.870 & 96.479 \\
\hline DI194CF 1b.2d & 62.200 & 0.617 & 17.090 & 5.050 & 0.060 & 1.523 & 5.270 & 0.698 & 0.966 & 93.474 \\
\hline DI194CF1b.2d-pt2 & 62.040 & 0.597 & 16.470 & 5.060 & 0.132 & $\mathrm{I} .578$ & 5.090 & 2.220 & 1.510 & 94.697 \\
\hline DI194CF $1 \mathrm{~b} .2 \mathrm{e}$ & 61.960 & 0.475 & 16.910 & 4.060 & 0.076 & 1.299 & 3.910 & 5.280 & 1.480 & 95.451 \\
\hline DI194CF2.1A & 68.120 & 0.512 & 15.960 & 2.290 & 0.029 & 0.277 & 2.250 & 4.570 & 2.620 & 96.629 \\
\hline DI194CF2.1B & 61.970 & 0.052 & 20.690 & 0.686 & 0.019 & 0.021 & 3.610 & 11.520 & 0.908 & 99.476 \\
\hline D1194CF2.1B-pt2 & 61.540 & 0.018 & 21.650 & 0.677 & 0.000 & 0.036 & 4.360 & 11.340 & 0.739 & 100.360 \\
\hline DI194CF2.1C & 72.680 & 0.441 & 12.060 & 1.880 & 0.045 & 0.121 & 1.264 & 3.720 & 2.330 & 94.541 \\
\hline DI194CF3.1A & 62.980 & 0.440 & 15.360 & 5.410 & 0.119 & 2.330 & 4.000 & 4.780 & 1.540 & 96.959 \\
\hline D1194CF3.1A-pt2 & 61.770 & 0.314 & 19.770 & 3.780 & 0.094 & 1.414 & 5.950 & 3.170 & 1.181 & 97.443 \\
\hline DI194CF3.2A-pt3 & 68.310 & 0.283 & 8.660 & 7.220 & 0.260 & 6.630 & 1.650 & 1.600 & 2.200 & 96.813 \\
\hline DI194CF3.2A-pt4 & 67.290 & 0.581 & 13.800 & 5.210 & 0.096 & 2.230 & 2.040 & 3.180 & 2.880 & 97.307 \\
\hline DI194CF3.2B & 69.720 & 0.706 & 12.940 & 4.190 & 0.087 & 1.339 & 1.610 & 2.180 & 2.950 & 95.722 \\
\hline DI194CF3.2B-pt2 & 69.310 & 0.826 & 13.280 & 3.970 & 0.047 & 1.171 & 1.440 & 2.450 & 3.050 & 95.544 \\
\hline D1194CF3.2B-pt3 & 67.610 & 0.684 & 14.650 & 3.930 & 0.081 & 1.190 & 1.810 & 2.660 & 3.060 & 95.675 \\
\hline DI194CF3.2C & 68.290 & 0.233 & 15.830 & 1.700 & 0.045 & 0.431 & 1.910 & 5.840 & 2.840 & 97.119 \\
\hline DI 194CF3.2C-pt2 & 76.990 & 0.545 & 9.230 & 2.060 & 0.025 & 0.579 & 0.840 & 2.650 & 2.830 & 95.749 \\
\hline D1194CF3.2C-pt3 & 72.290 & 0.936 & 11.100 & 3.370 & 0.059 & 1.267 & 1.091 & 2.260 & 2.930 & 95.303 \\
\hline
\end{tabular}


Table D-2:

Continued

\begin{tabular}{|lrrrrrrrrrr|}
\hline & SiO2 & TiO2 & Al2O3 & FeO* & MnO & MgO & CaO & Na2O & K2O & total \\
\hline DI194CF4.1A & 61.210 & 0.460 & 17.350 & 3.900 & 0.064 & 1.349 & 5.050 & 7.760 & 1.330 & 98.473 \\
DI194CF4.1A-pt2 & 62.630 & 0.584 & 14.670 & 5.640 & 0.075 & 2.010 & 4.690 & 4.730 & 1.780 & 96.809 \\
DI194CF4.1B & 62.370 & 0.677 & 14.860 & 5.720 & 0.112 & 1.980 & 4.710 & 5.030 & 1.830 & 97.289 \\
DI194CF4.1C & 64.110 & 0.437 & 15.330 & 4.430 & 0.101 & 1.760 & 3.770 & 5.190 & 1.730 & 96.858 \\
DI194CF4.1C-pt2 & 64.620 & 0.456 & 14.650 & 4.490 & 0.096 & 1.820 & 3.670 & 4.210 & 1.800 & 95.812 \\
DI194CF4.1D & 60.520 & 0.565 & 16.700 & 4.980 & 0.106 & 1.960 & 5.300 & 6.320 & 1.280 & 97.731 \\
DI194CF4.1D-pt2 & 61.030 & 0.671 & 14.890 & 5.870 & 0.087 & 2.370 & 4.620 & 4.870 & 1.570 & 95.978 \\
& & & & & & & & & & \\
Ave (all MI's) & $\mathbf{6 5 . 2 8 9}$ & $\mathbf{0 . 4 9 1}$ & $\mathbf{1 5 . 3 3 4}$ & $\mathbf{3 . 9 8 8}$ & $\mathbf{0 . 0 7 7}$ & $\mathbf{1 . 4 9 1}$ & $\mathbf{3 . 3 9 8}$ & $\mathbf{4 . 4 0 7}$ & $\mathbf{1 . 9 5 0}$ & $\mathbf{9 6 . 4 2 6}$ \\
s.d. (all MI's) & $\mathbf{4 . 2 4 7}$ & $\mathbf{0 . 2 0 3}$ & $\mathbf{2 . 9 2 3}$ & $\mathbf{1 . 5 5 9}$ & $\mathbf{0 . 0 4 9}$ & $\mathbf{1 . 2 0 9}$ & $\mathbf{1 . 5 1 5}$ & $\mathbf{2 . 5 0 3}$ & $\mathbf{0 . 7 0 4}$ & $\mathbf{1 . 5 7 1}$ \\
\hline
\end{tabular}


Table D-3: Average microprobe analysis and standard deviations for multiple point analyses

\begin{tabular}{|c|c|c|c|c|c|c|}
\hline \multicolumn{7}{|l|}{$1004-421$} \\
\hline Element & $\begin{array}{c}\text { Ave Px } \\
\text { MI1 }\end{array}$ & s.d. & $\begin{array}{r}\text { Ave PX } \\
\text { MI } 2\end{array}$ & s.d. & $\begin{array}{r}\text { Ave Pl } \\
\text { MI } 1\end{array}$ & s.d. \\
\hline $\mathrm{SiO} 2$ & 70.050 & 2.185 & 70.635 & 0.460 & 75.27 & 12.057 \\
\hline $\mathrm{TiO} 2$ & 0.026 & 0.009 & 0.017 & - & 0.357 & 0.254 \\
\hline A1203 & 15.628 & 1.709 & 15.080 & 0.042 & 8.377 & 5.656 \\
\hline $\mathrm{FeO}$ & 0.236 & 0.015 & 0.260 & 0.010 & 5.39 & 4.083 \\
\hline $\mathrm{MnO}$ & 0.021 & 0.007 & 0.014 & - & 0.092 & 0.049 \\
\hline $\mathrm{MgO}$ & 0.020 & 0.012 & 0.000 & - & 1.617 & 1.658 \\
\hline $\mathrm{CaO}$ & 1.166 & 0.041 & 1.198 & 0.083 & 1.891 & 1.081 \\
\hline $\mathrm{Na} 20$ & 0.890 & 0.204 & 1.073 & 0.037 & 4.43 & 2.69 \\
\hline K20 & 1.184 & 0.237 & 1.370 & 0.000 & 0.211 & 0.159 \\
\hline Total & 89.221 & & 89.646 & & 97.635 & 1.439 \\
\hline
\end{tabular}

\begin{tabular}{|lrrrrrr|}
\hline M82-11 & & & & & & \\
Element & Ave Plag & s.d. & Ave Px & s.d. & Ave Px & s.d. \\
& MI1 & & MI1 & & MI2 & \\
$\mathrm{SiO} 2$ & 70.465 & 0.148 & 70.367 & 0.420 & 69.680 & 0.184 \\
$\mathrm{TiO} 2$ & 0.447 & 0.334 & 0.387 & 0.017 & 0.370 & 0.028 \\
$\mathrm{Al} 203$ & 12.020 & 3.875 & 17.627 & 0.202 & 17.910 & 0.141 \\
$\mathrm{FeO}$ & 5.070 & 3.083 & 1.693 & 0.105 & 1.370 & 0.113 \\
$\mathrm{MnO}$ & 0.138 & 0.134 & 0.068 & 0.022 & 0.052 & 0.016 \\
$\mathrm{MgO}$ & 1.519 & 1.063 & 0.652 & 0.266 & 0.188 & 0.019 \\
$\mathrm{CaO}$ & 1.690 & 1.061 & 2.100 & 0.022 & 2.200 & 0.141 \\
$\mathrm{Na} 20$ & 5.160 & 2.022 & 1.469 & 0.469 & 2.190 & 0.141 \\
$\mathrm{~K} 20$ & 4.275 & 0.148 & 1.797 & 0.074 & 2.870 & 0.071 \\
Total & 100.783 & 0.520 & 96.160 & 0.043 & 96.829 & 0.061 \\
\hline
\end{tabular}


Table D-3 (Cont.)

\begin{tabular}{|c|c|c|c|c|}
\hline \multicolumn{5}{|l|}{$1004-414$} \\
\hline Element & Ave PI MI2 & s.d. & $\begin{array}{l}\text { Ave } \mathrm{Hbl} \\
\mathrm{MI}\end{array}$ & s.d. \\
\hline $\mathrm{SiO} 2$ & 61.770 & 1.468 & 69.450 & 2.051 \\
\hline $\mathrm{TiO} 2$ & 0.693 & 0.896 & 0.195 & 0.121 \\
\hline A 1203 & 15.687 & 7.398 & 2.880 & 0.297 \\
\hline $\mathrm{FeO}$ & 4.866 & 5.471 & 0.860 & 0.580 \\
\hline $\mathrm{MnO}$ & 0.104 & 0.147 & - & - \\
\hline $\mathrm{MgO}$ & 2.071 & 2.821 & 5.570 & 1.230 \\
\hline $\mathrm{CaO}$ & 4.650 & 1.678 & 5.555 & 0.403 \\
\hline $\mathrm{Na} 20$ & 8.147 & 4.272 & 3.560 & 1.358 \\
\hline K20 & 1.897 & 0.663 & 0.473 & 0.027 \\
\hline Total & 99.885 & 1.114 & 88.549 & 1.921 \\
\hline
\end{tabular}

\begin{tabular}{|c|c|c|}
\hline $91-68$ & & \\
\hline Element & $\begin{array}{l}\text { Ave Plag } \\
\text { MI }\end{array}$ & s.d. \\
\hline $\mathrm{SiO} 2$ & 69.3875 & 1.234 \\
\hline TiO2 & 0.5885 & 0.079 \\
\hline $\mathrm{Al} 203$ & 18.555 & 1.132 \\
\hline $\mathrm{FeO}$ & 1.49575 & 0.413 \\
\hline $\mathrm{MnO}$ & 0.05025 & 0.016 \\
\hline $\mathrm{MgO}$ & 0.19775 & 0.199 \\
\hline $\mathrm{CaO}$ & 2.4375 & 0.314 \\
\hline $\mathrm{Na} 20$ & 1.5675 & 0.022 \\
\hline $\mathrm{K} 20$ & 2.065 & 0.066 \\
\hline Total & 96.34475 & 0.904 \\
\hline
\end{tabular}


Table D-4: Average compostitions used for plotting differentiation trends

\begin{tabular}{|lrrrrrr|}
\hline & $\begin{array}{c}\text { Average } \\
\text { Groundmass }\end{array}$ & $\begin{array}{c}\text { Average } \\
\text { Bulk Rock } \\
(1869-1913)\end{array}$ & $\begin{array}{c}\text { Average } \\
\text { Plagioclase* }\end{array}$ & $\begin{array}{c}\text { Average } \\
\text { Clinopyroxene }\end{array}$ & $\begin{array}{c}\text { Average } \\
\text { Orthopyroxene }\end{array}$ & $\begin{array}{c}\text { Average } \\
\text { Hornblende }\end{array}$ \\
$\mathrm{SiO} 2$ & 65.86 & 59.852 & 51.151 & 51.358 & 53.154 & 42.885 \\
$\mathrm{TiO} 2$ & 0.746 & 0.665 & 0.02 & 0.559 & 0.1958 & 2.582 \\
$\mathrm{Al2O} 3$ & 15.98 & 17.735 & 29.35 & 2.673 & 1.4656 & 11.812 \\
$\mathrm{FeO} *$ & 4.247 & 5.47 & 0.637 & 8.455 & 18.04 & 11.915 \\
$\mathrm{MnO}$ & 0.177 & 0.101 & 0.012 & 0.238 & 0.5032 & 0.195 \\
$\mathrm{MgO}$ & 1.457 & 3.175 & 0.126 & 15.465 & 26.964 & 14.355 \\
$\mathrm{CaO}$ & 3.666 & 6.003 & 12.39 & 20.316 & 1.1726 & 11.242 \\
$\mathrm{Na} 2 \mathrm{O}$ & 5.299 & 4.611 & 5.771 & 0.449 & 0.0366 & 2.643 \\
$\mathrm{~K} 2 \mathrm{O}$ & 2.204 & 1.34 & 0.159 & - & 0.0054 & 0.402 \\
$\mathrm{P2O}$ & 0.233 & 0.197 & $\mathrm{n} / \mathrm{a}$ & $\mathrm{n} / \mathrm{a}$ & $\mathrm{n} / \mathrm{a}$ & $\mathrm{n} / \mathrm{a}$ \\
$\mathrm{Total}$ & 99.869 & 99.149 & 99.616 & 99.513 & 101.5372 & 98.031 \\
\hline
\end{tabular}

* Plagioclase analysis is a combination of numerous data points aquired from this study and Luhr \& Carmichael, 1980. All other values are from Lurh and carmichael 1980 \& 1990. 